\title{
VERIFICATION OF THE DEFENSE WASTE PROCESSING FACILITY'S (DWPF) PROCESS DIGESTION METHOD FOR THE SLUDGE BATCH 7A QUALIFICATION SAMPLE
}

\author{
D. R. Click \\ T. B. Edwards \\ M.A. Jones \\ B.J. Wiedenman
}

March 14, 2011

Analytical Development

Savannah River National Laboratory

Aiken, SC 29808

Prepared for the U.S. Department of Energy Under Contract Number DE-AC09-08SR22470

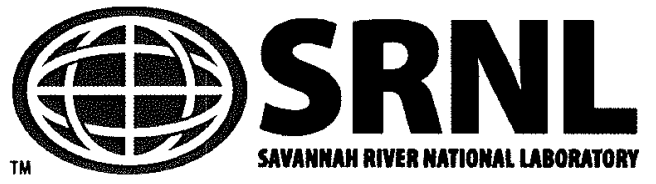


This page intentionally left blank 


\section{DISCLAIMER}

This work was prepared under an agreement with and funded by the U.S. Government. Neither the U.S. Government or its employees, nor any of its contractors, subcontractors or their employees, makes any express or implied:

1. warranty or assumes any legal liability for the accuracy, completeness, or for the use or results of such use of any information, product, or process disclosed;

2. representation that such use or results of such use would not infringe privately owned rights; or

3. endorsement or recommendation of any specifically identified commercial product, process, or service. Any views and opinions of authors expressed in this work do not necessarily state or reflect those of the United States Government, or its contractors, or subcontractors.

Printed in the United States of America

Prepared For

U.S. Department of Energy 
SRNL-STI-2011-00158, REVISION 0

This page intentionally left blank 
Key Words:

method development, analytical process, $S B 7$,

waste compliance

Retention:

Permanent

\title{
VERIFICATION OF THE DEFENSE WASTE PROCESSING FACILITY'S (DWPF) PROCESS DIGESTION METHOD FOR THE SLUDGE BATCH 7A QUALIFICATION SAMPLE
}

\author{
D. R. Click \\ T. B. Edwards \\ M.A. Jones \\ B.J. Wiedenman
}

March 14, 2011

Analytical Development

Savannah River National Laboratory Aiken, SC 29808

Prepared for the U.S. Department of Energy Under Contract Number DE-AC09-08SR22470

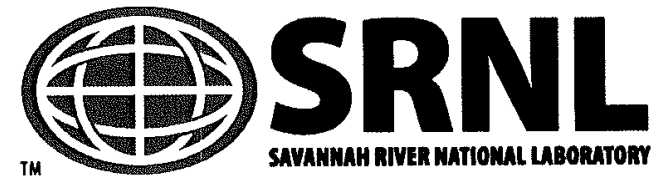


SRNL-STI-2011-00158, REVISION 0

\section{REVIEWS AND APPROVALS}

D.R. Click, Author, Analytical Development, SRNL

Date

T.B. Edwards, Co-Author, ACES, SRNL

Date

M.A. Jones, Co-Author, Analytical Development, SRNL

Date

B.J. Wiedenman, Co-Author, Analytical Development, SRNL

Date

C.J. Coleman, Technical Reviewer, Analytical Development, SRNL

Date

C.C. Herman, Manager, DWPF Programs, SRNL,

Date

$\overline{\text { C.M. Gregory, Manager, Spectroscopy and Separations, Analytical Development, SRNL } \quad \text { Date }}$

J.E. Occhipinti, Manager, WS Engineering, SRR

Date 
SRNL-STI-2011-00158, REVISION 0

This page intentionally left blank 


\section{TABLE OF CONTENTS}

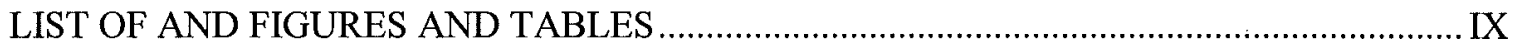

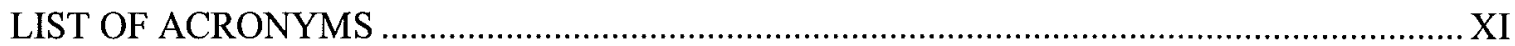

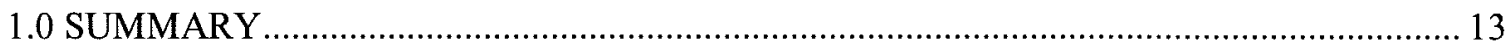

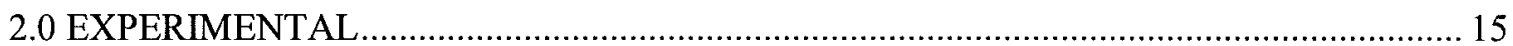

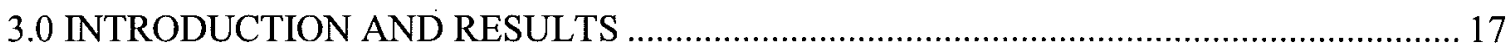

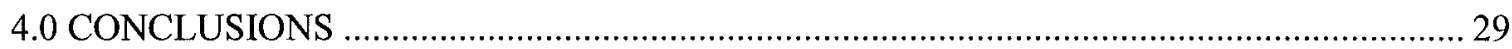

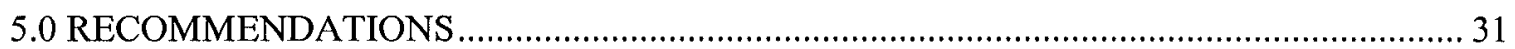

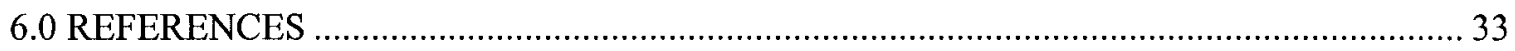

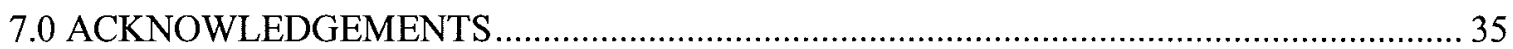

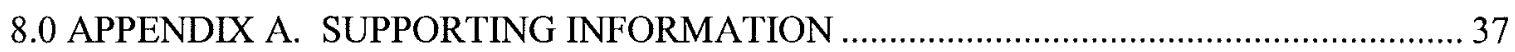




\section{SRNL-STI-2011-00158, REVISION 0}

This page intentionally left blank 


\section{SRNL-STI-2011-00158, REVISION 0}

\section{LIST OF AND FIGURES AND TABLES}

Table 3-1. Elemental concentrations of SB7a SRAT Receipt radioactive sludge slurry obtained from ICP-AES analysis of Aqua Regia, DWPF Cold Chem method and Sodium Peroxide/Hydroxide Fusion digestions. Values are presented on a weight percent (wt\%) of total dried solids basis.

Table 3-2 Statistical comparison of Aqua Regia, DWPF Cold Chem method and Sodium Peroxide/Hydroxide Fusion digestions of SB7a SRAT Receipt sludge. Digestions not having the same font, those that are not underlined or those separated with a less than sign are statistically different at the $5 \%$ significance level.

Table 3-3. Elemental concentrations of SB7a SRAT Product radioactive sludge slurry obtained from ICP-AES analysis of Aqua Regia, DWPF Cold Chem method and Sodium Peroxide/Hydroxide Fusion digestions. Values are presented on a weight percent $(\mathrm{Wt} \%)$ total dried solids basis.

Table 3-4. Statistical comparison of Aqua Regia, DWPF Cold Chem method and Sodium Peroxide/Hydroxide Fusion digestions of SB7a SRAT Product sludge. Digestions not having the same font, those that are not underlined or those separated with a less than sign are statistically different at the $5 \%$ significance level.

Table 3-5. Elemental concentrations of ARG standard from ICP-AES analysis of Aqua Regia, DWPF Cold Chem method and Sodium Peroxide/Hydroxide Fusion digestions performed concurrently with SB7a SRAT Receipt Sample. Values are presented on a weight percent $(\mathrm{Wt} \%)$ total solids basis.

Table 3-6. Continuation of elemental concentrations of ARG standard from ICP-AES analysis of Aqua Regia, DWPF Cold Chem method and Sodium Peroxide/Hydroxide Fusion digestions performed concurrently with SB7a SRAT Receipt Sample. Values are presented on a weight percent $(\mathrm{Wt} \%)$ total solids basis. ...26

Table 3-7. Elemental concentrations of ARG standard from ICP-AES analysis of Aqua Regia, DWPF Cold Chem method and Sodium Peroxide/Hydroxide Fusion digestions performed concurrently with SB7a SRAT Product sample. Values are presented on a weight percent $(\mathrm{Wt} \%)$ total solids basis.

Table 3-8. Continuation of elemental concentrations of ARG standard from ICP-AES analysis of Aqua Regia, DWPF Cold Chem method and Sodium Peroxide/Hydroxide Fusion digestions performed concurrently with SB7a SRAT Product sample. Values are presented on a weight percent $(\mathrm{Wt} \%)$ total solids basis. ...28 
SRNL-STI-2011-00158, REVISION 0

This page intentionally left blank 


\section{LIST OF ACRONYMS}

$\begin{array}{ll}\text { AD } & \text { Analytical Development } \\ \text { AR } & \text { Aqua Regia } \\ \text { ARG } & \text { Analytical Reference Glass } \\ \text { CC } & \text { Cold Chem } \\ \text { DI } & \text { De-Ionized } \\ \text { DOE } & \text { Department of Energy } \\ \text { DWPF } & \text { Defense Waste Processing Facility } \\ \text { ICP-AES } & \text { Inductively Coupled Plasma - Atomic Emission Spectroscopy } \\ \text { LWO } & \text { Liquid Waste Operations } \\ \text { PF } & \text { Sodium Peroxide/Hydroxide Fusion } \\ \text { SB } & \text { Sludge Batch } \\ \text { SME } & \text { Slurry Mix Evaporator } \\ \text { SRAT } & \text { Sludge Receipt and Adjustment Tank } \\ \text { SRNL } & \text { Savannah River National Laboratory } \\ \text { WAPS } & \text { Waste Acceptance Product Specification } \\ \text { C-XRD } & \text { Contained - X-Ray Diffraction }\end{array}$


SRNL-STI-2011-00158, REVISION 0

This page intentionally left blank 
SRNL-STI-2011-00158, REVISION 0

\subsection{SUMMARY}

For each sludge batch that is processed in the Defense Waste Processing Facility (DWPF), the Savannah River National Laboratory (SRNL) performs confirmation of the applicability of the digestion method to be used by the DWPF lab for elemental analysis of Sludge Receipt and Adjustment Tank (SRAT) receipt samples and SRAT product process control samples. DWPF SRAT samples are typically dissolved using a room temperature $\mathrm{HF}-\mathrm{HNO}_{3}$ acid dissolution (i.e., DWPF Cold Chem Method, see DWPF Procedure SW4-15.201) and then analyzed by inductively coupled plasma - atomic emission spectroscopy (ICPAES).

This report contains the results and comparison of data generated from performing the Aqua Regia (AR), Sodium Peroxide/Hydroxide Fusion (PF) and DWPF Cold Chem (CC) method digestions of Sludge Batch 7a (SB7a) SRAT Receipt and SB7a SRAT Product samples. The SB7a SRAT Receipt and SB7a SRAT Product samples were prepared in the SRNL Shielded Cells, and the SRAT Receipt material is representative of the sludge that constitutes the SB7a Batch or qualification composition. This is the sludge in Tank 51 that is to be transferred into Tank 40, which will contain the heel of Sludge Batch 6 (SB6), to form the SB7a Blend composition.

Observations and results from the SRAT Receipt digestions include the following:

- Brown undissolved solids and white solids remained in the solutions generated from the CC digestions after all acid addition steps and dilutions were performed.

- Statistically larger Al concentration measurements are seen in the PF digestions when compared to the $\mathrm{AR}$ and $\mathrm{CC}$ methods.

- The mean $\mathrm{Fe}$ concentration is $\sim 9 \%$ and $\sim 12 \%$ lower in the $\mathrm{CC}$ digestions relative to the $\mathrm{PF}$ and AR digestions, respectively.

- The means for $\mathrm{K}$ were also statistically significant and in this round of experiments a large relative difference between the digestions was noted as well.

- For $\mathrm{Mn}$, the relative difference between the $\mathrm{AR}$ mean and $\mathrm{CC}$ mean is $\sim 6 \%$ and a statistical difference in the means is observed. The relative difference between the PF and CC mean is $\sim 4 \%$ and there is not a statistical difference in the means,

- The mean Ni concentration is $\sim 10 \%$ and $\sim 13 \%$ lower in the CC digestions relative to the PF and AR digestions, respectively.

- Thorium should be determined from the PF digestion.

- A statistical difference of means was also noted for the minor elements $\mathrm{Cr}, \mathrm{Cu}$ and $\mathrm{Ti}$.

- $\mathrm{Ca}, \mathrm{Mg}, \mathrm{Mn}, \mathrm{Na}, \mathrm{Ti}, \mathrm{U}$ and $\mathrm{Zr}$ appear to dissolve in the time allotted based upon results from ICPAES data (please see the complete statistical comparison).

Observations and results from the SRAT Product digestions include the following:

- Brown undissolved solids and white solids remained in the solutions generated from the CC digestions after all acid addition steps and dilutions were performed.

- Statistically larger Al concentration measurements are seen in the PF digestions when compared against the $\mathrm{AR}$ and $\mathrm{CC}$ methods.

- $\mathrm{Fe}$ is $\sim 7 \%$ lower in the $\mathrm{CC}$ digestions relative to the PF and $\mathrm{AR}$ digestion.

- A statistical difference of means is observed for Mg comparing the CC mean to the $\mathrm{AR}$ and $\mathrm{PF}$ means. The AR and PF means are $\sim 47 \%$ lower than the CC mean. However, the large \%RSD associated with the $\mathrm{CC}$ measurements indicates the concentration in the diluted sample was very close to the ICP-AES detection limit and therefore it is the opinion of the author that the CC 
value, in this case, should not be used. No statistical difference was noted for $\mathrm{Mg}$ between the $\mathrm{AR}$ and PF means. There was no statistical difference observed for the SRAT Receipt between the three digestion methods.

- $\mathrm{Ni}$ is $\sim 10 \%$ and $\sim 12 \%$ lower in the $\mathrm{CC}$ digestions relative to the PF and AR digestions, respectively.

- Thorium should be determined from the PF digestion.

- A statistical difference of means was also noted for the minor elements $\mathrm{Cr}, \mathrm{Cu}, \mathrm{K}$ and $\mathrm{Ti}$.

- $\mathrm{Ca}, \mathrm{Mn}, \mathrm{Na}, \mathrm{Ti}, \mathrm{U}$ and $\mathrm{Zr}$ appear to dissolve in the time allotted based upon the results from ICPAES data (please see the complete statistical comparison).

Based on the SB7a analytical comparisons, SRNL recommends the following:

- $\mathrm{Al}, \mathrm{Fe}, \mathrm{Ni}$ and Th should be analyzed by the peroxide fusion method for SB7a. Mn can be measured using either the CC of PF method but monitored closely and the highest $\mathrm{Mn}$ concentration between the two digestions should be used. Although $\mathrm{K}$ is a minor element, large relative differences are noted in this report between the different digestions and the DWPF should also monitor the $\mathrm{K}$ concentration. ICP-AES detection limit issues resulted in an abnormally high concentration for $\mathrm{Mg}$ in the SRAT product. The \%RSD associated with sample results should be monitored to indicate potential issues with ICP-AES detection limits.

- The DWPF CC method was originally developed to be used for SME analyses. Given continuous visual observations of solids in the $\mathrm{CC}$ digestions prior to this report, undissolved $\mathrm{Fe}$ observed and noted in this report for SB7a, and potential issues with accurate $\mathrm{Al}$ measurements when processing HM waste, the DWPF lab should consider a different digestion scheme that relieves some of these issues.

- The results of this study need to be assessed against the glass processing control algorithms of the DWPF to determine the potential impact of any statistical difference of the means between elements. Specifically, the DWPF should investigate if comparisons between the elemental concentrations of the SME product (adjusted for frit addition) obtained by the mixed acid and peroxide fusion digestion and the SRAT Receipt and SRAT Product elemental concentrations obtained via the DWPF CC method provide insight into the adequacy of the CC method for analysis of the SRAT Product. If a consistent difference in elemental concentrations is revealed, another type of digestion (i.e. sodium peroxide/hydroxide fusion) should be used to determine the concentration of the element in question. Particular emphasis should be placed on monitoring $\mathrm{Al}$, $\mathrm{Fe}, \mathrm{K}, \mathrm{Ni}, \mathrm{Mn}$ and Th concentrations in SB7a. 
SRNL-STI-2011-00158, REVISION 0

\subsection{EXPERIMENTAL}

The radioactive sludge slurry used in this study for verification of the DWPF CC method is from the three liter qualification sample of Tank 51 sludge slurry received at SRNL on September $18^{\text {th }}, 2010$. The sample was delivered to SRNL, characterized and then modified by a series of wash/decant cycles to match the Tank Farm endpoint as of October 13, 2010. The sludge used in this testing corresponded to SC-11, the washed SB7a sample identified by Pareizs et al. in SRNL-L3100-2010-00252, which is the SB7a qualification sample or the SRAT Receipt sample.

The sludge samples were dissolved in quadruplicate in the SRNL Shielded Cells facility in a manner similar to the DWPF CC method, and by PF and AR digestion. For detailed steps of the PF digestion, see ADS procedure 2502. ${ }^{1}$ For detailed steps of the AR digestion, see ADS procedure $2226 .{ }^{2}$ Three replicate dissolutions of the analytical reference glass $(A R G)$ standard were performed concurrently with each set of digestions for quality control purposes. The ARG results are then evaluated by comparing the measured results against a two sigma variation of the standard deviation associated with measured concentrations obtained from a round-robin consensus study. For the SRAT Receipt material, $\mathrm{Si}$ and $\mathrm{Zr}$ (as expected) were low and flagged as being outside of the 2 sigma limits for the AR digestions. Ca and $\mathrm{K}$ were flagged as being outside the 2 sigma limits (slightly high) for the PF digestions. For the SRAT product material, Si and $\mathrm{Zr}$ (as expected) were flagged as being outside of the 2 sigma limits for the AR digestions as well as Ti. Ca and Mg were flagged as being outside of the 2 sigma limits for the CC digestions. Ca and $\mathrm{Mn}$ were flagged as being outside of the 2 sigma limits for the PF digestions. Additional quality control measures included ICP-AES analyses of a multi-element standard as a check for ICP-AES accuracy independent of digestions. Elements in this standard included $\mathrm{Al}, \mathrm{Fe}, \mathrm{Mn}, \mathrm{Ni}, \mathrm{Na}$ and S. All measured values were within $10 \%$ of the known concentrations for these elements in the standard analyzed concurrently with the PF and AR digestions. For the standard analyzed concurrently with the CC samples, Ni was $10-11 \%$ low.

The CC method digestion (see DWPF Procedure SW4-15.201) involved adding $25 \mathrm{~mL}$ of concentrated $\mathrm{HF}$ to radioactive sludge slurry ( $\sim 3.5 \mathrm{~g}$ for the SRAT Receipt at $18.1 \mathrm{wt} \%$ total solids and $\sim 3.5 \mathrm{~g}$ for the SRAT Product at $25.4 \mathrm{wt} \%$ total solids) and stirring for $1 \mathrm{hr}$. Then, $25 \mathrm{~mL}$ of concentrated $\mathrm{HNO}_{3}$ was added and the mixture was stirred for an additional 30 minutes. Undissolved brown solids remained in each digestion bottle after all the acid addition was complete. Each sample was then diluted with deionized (DI) water to $250 \mathrm{~mL}$ in a pre-weighed volumetric flask. The density of the solution was obtained from the weight of the $250 \mathrm{~mL}$ of solution. Approximately $15 \mathrm{~g}$ of solution was taken from the $250 \mathrm{~mL}$ volumetric flask and added to a $100 \mathrm{~mL}$ volumetric flask and subsequently diluted with DI water. After several days, an attempt was made to recover the insoluble/precipitated solids from one of the samples by filtration but the extremity dose rate of the solids prevented personnel from removing the sample from the shielded cells. 
SRNL-STI-2011-00158, REVISION 0

This page intentionally left blank 
SRNL-STI-2011-00158, REVISION 0

\subsection{INTRODUCTION AND RESULTS}

The DWPF is currently processing and immobilizing radioactive sludge slurry into a durable borosilicate glass. The DWPF has already processed six sludge batches (Sludge Batch 1A, Sludge Batch 1B, Sludge Batch 2, Sludge Batch 3, Sludge Batch 4, and Sludge Batch 5) and is currently processing a seventh (Sludge Batch 6). A sludge batch is defined as a single tank of sludge or a combination of sludges from different tanks that has been or will be qualified before being transferred to DWPF. Thus, following the sludge batch preparation plan of the Liquid Waste Organization (LWO), the qualified sludge in Tank 51 is to be blended with the heel of the previous sludge batch in Tank 40. The sludge being qualified at the SRNL (referred to as a "batch" composition in sludge batch planning) is to be combined with the heel of the previous sludge batch in DWPF to yield the "blend" composition. The next batch of radioactive sludge slurry to be processed by the DWPF is SB7a. The subject of this report is the SB7a material from Tank 51 that is being qualified at SRNL.

The statistical results of the SB7a samples generated from this study are provided in Table A1 of Appendix A. The results from each type of digestion are summarized in Table 3-1 for the SRAT Receipt and Table 3-3 for the SRAT Product samples. The ICP-AES results of the seventeen elements that are analyzed by the DWPF lab are presented on a weight percent (wt $\%)$ of total solids basis. A statistical comparison of the means from the SRAT Receipt and SRAT Product for all three digestions could not be performed for $\mathrm{B}, \mathrm{Ca}, \mathrm{Li}, \mathrm{Na}, \mathrm{Si}$ or $\mathrm{Zr}$. B was less than the detection limit in the AR and PF digestions and $\mathrm{B}$ is leached from the borosilicate spray chamber of the ICP-AES instrument due to the presence of HF in the $\mathrm{CC}$ digestions. $\mathrm{Ca}$ is a contaminant in the PF reagents (the PF blank Ca concentration was $1500 \mu \mathrm{g} / \mathrm{g}$ ) and therefore only the means from the $\mathrm{AR}$ and $\mathrm{CC}$ digestions were compared. A less than value was reported for the Li concentration from the solutions generated by the $\mathrm{CC}$ and PF digestions. Na is added as part of the reagents used for PF digestions and only the means of the $\mathrm{CC}$ and $\mathrm{AR}$ digestions were compared. Si is leached from the ICP-AES instrument due to the presence of $\mathrm{HF}$ in the CC digestions and $\mathrm{Si}$ is known to not dissolve well in AR digestions. $\mathrm{Zr}$ could not be included in a statistical comparison of the means because the PF digestion utilizes a Zr crucible; therefore, only the AR and CC results were compared. However, the $\mathrm{Zr}$ result from the AR digestions was low. $\mathrm{Zr}$ dissolves better when HF is present and this can readily be seen from the ARG-1 analysis results. In addition, for the SRAT Product, the $\mathrm{K}$ concentrations could not be compared because $\mathrm{K}$ was less than the minimum detection limit in the PF and CC digestions.

Statistical comparisons of the data from the three digestion methods (for $\mathrm{Na}$ and $\mathrm{Zr}$ there are only two digestion methods) are provided in Exhibit A1 in Appendix A. The results were generated using JMP Version 7.0.2. ${ }^{3}$ The plots of this exhibit show a $95 \%$ confidence interval for the mean (a mean diamond) of each set of measurements. For each element, the mean concentration of the samples by each digestion method is provided, and means that are not connected by the same letter in the listing of the exhibit are significantly different at a significance level of 5\%. For example consider the SRAT Product Fe measurements. The results of the exhibit indicate that the mean of the $\mathrm{CC}$ results differs from the means of the PF and AR results.

For the $\mathrm{Na}$ and $\mathrm{Zr}$ comparisons, the JMP output from an analysis of variance of the measurements for two digestions is provided, and only the $95 \%$ confidence mean diamond of each digestion is shown. Overlap marks show for each diamond, and overlap marks in one diamond that are closer to the mean of another diamond than that diamond's overlap marks indicate that those two groups are not different at the $95 \%$ confidence level. The visual comparisons are supported by an F test that compares the means of the AR and $\mathrm{CC}$ digestions for $\mathrm{Na}$ and $\mathrm{Zr}$ and the means of the $\mathrm{AR}$ and $\mathrm{PF}$ digestions for Si. If the $\mathrm{p}$ value is less than 0.05 , then the means are statistically different at the $5 \%$ level. From Exhibit A1, there is no 
statistical difference in the AR and CC means for Na for the SRAT Product or the SRAT Receipt samples.

Summaries of the statistical comparisons of Exhibit Al are shown in Table 3-3 and Table 3-4 Digestion types not having a similar font, those that are not underlined or those separated by a less than sign are statistically different at the 5\% significance level. Consider the SRAT Product Fe results, the averages of the Fe measurements by PF and AR method digestions are statistically the same, but these means are statistically different from the average obtained from the DWPF CC digestion (which is indicated by a less than sign separating the digestion types). ARG results are presented and compared for each digestion type for the SRAT Receipt and SRAT Product samples in Table 3-5 through Table 3-8, including a similar statistical comparison of the means.

During verification of the DWPF CC method for previous sludge batches, boehmite $(\mathrm{AlO}(\mathrm{OH}))$, muscovite $(\mathrm{K}, \mathrm{Na})(\mathrm{Al}, \mathrm{Mg}, \mathrm{Fe})_{2}\left(\mathrm{Si}_{3.1} \mathrm{Al}_{0.9}\right) \mathrm{O}_{10}(\mathrm{OH})_{2}$, silicon dioxide $\left(\mathrm{SiO}_{2}\right)$, dipotassium sodium aluminum fluoride $\left(\mathrm{K}_{2} \mathrm{NaAl}_{3} \mathrm{~F}_{12}\right)$, dipotassium aluminum pentafluoride $\left(\mathrm{K}_{2} \mathrm{AlF}_{5}\right)$, aluminum fluoride $\left(\mathrm{AlF}_{3}\right)$, chiolite $\left(\mathrm{Na}_{5} \mathrm{Al}_{3} \mathrm{~F}_{14}\right)$, cryolite $\left(\mathrm{Na}_{3} \mathrm{AlF}_{6}\right)$, sodium magnesium aluminum hexafluoride $\left(\mathrm{NaMgAlF}_{6}\right)$, iron zirconium hexafluoride $\left(\mathrm{FeZrF}_{6}\right)$, disodium iron aluminum heptafluoride $\left(\mathrm{Na}_{2} \mathrm{FeAlF}_{7}\right)$, and calcium thorium fluoride $\left(\mathrm{Ca}_{0.5} \mathrm{Th}_{0.5} \mathrm{~F}_{3}\right)$ have been found. ${ }^{4}$ 
Table 3-1. Elemental concentrations of SB7a SRAT Receipt radioactive sludge slurry obtained from ICPAES analysis of Aqua Regia, DWPF Cold Chem method and Sodium Peroxide/Hydroxide Fusion digestions. Values are presented on a weight percent $(\mathrm{wt} \%)$ of total dried solids basis.

\begin{tabular}{|c|c|c|c|c|c|c|}
\hline $\begin{array}{l}\text { Digestion } \\
\text { Method } \rightarrow\end{array}$ & \multicolumn{2}{|c|}{ Aqua Regia } & \multicolumn{2}{|c|}{$\begin{array}{c}\mathrm{Na}_{2} \mathrm{O}_{2} / \mathrm{NaOH} \\
\text { Fusion } \\
\end{array}$} & \multicolumn{2}{|c|}{ DWPF Cold Chem } \\
\hline Element & Avg Wt\%* & $\% \mathrm{RSD}^{\#}$ & $\begin{array}{c}\text { Avg } \\
\text { Wt\%* }\end{array}$ & $\% \mathrm{RSD}^{\#}$ & Avg Wt\%* & $\% \mathrm{RSD}^{\#}$ \\
\hline $\mathrm{Al}$ & $9.67 \mathrm{E}+00$ & $3.7 \mathrm{E}+01$ & $1.06 \mathrm{E}+01$ & $3.1 \mathrm{E}+00$ & $9.83 \mathrm{E}+00$ & $1.2 \mathrm{E}+00$ \\
\hline B & $<2.85 \mathrm{E}-02$ & NA & $<2.90 \mathrm{E}-02$ & NA & NA & NA \\
\hline $\mathrm{Ca}$ & $5.56 \mathrm{E}-01$ & $2.0 \mathrm{E}+00$ & $6.82 \mathrm{E}-01$ & $4.2 \mathrm{E}+00$ & $7.02 \mathrm{E}-01^{\wedge}$ & $2.4 \mathrm{E}+01$ \\
\hline $\mathrm{Cr}$ & $4.34 \mathrm{E}-02$ & $6.9 \mathrm{E}+00$ & $5.18 \mathrm{E}-02$ & $6.6 \mathrm{E}+00$ & $4.59 \mathrm{E}-02$ & 4.7E-01 \\
\hline $\mathrm{Cu}$ & $3.94 \mathrm{E}-02$ & $4.6 \mathrm{E}+00$ & $4.13 \mathrm{E}-02$ & $3.4 \mathrm{E}+00$ & 3.641 & $2.6 \mathrm{E}+00$ \\
\hline $\mathrm{Fe}$ & $1.34 \mathrm{E}+01$ & $7.5 \mathrm{E}+00$ & $1.31 \mathrm{E}+01$ & $3.1 \mathrm{E}+00$ & $1.19 \mathrm{E}+01$ & $8.0 \mathrm{E}-01$ \\
\hline $\mathrm{K}$ & $6.72 \mathrm{E}-02$ & $5.3 \mathrm{E}+00$ & 4.63E-01 & $1.2 \mathrm{E}+01$ & $3.29 \mathrm{E}-01$ & $6.9 \mathrm{E}+00$ \\
\hline $\mathrm{Li}$ & $.80 \mathrm{E}-02$ & $3.4 \mathrm{E}+00$ & $<5.82 \mathrm{E}-02$ & $\mathrm{NA}$ & $<4.1$ & $\mathrm{NA}$ \\
\hline $\mathrm{Mg}$ & $2.76 \mathrm{E}-01$ & $5.9 \mathrm{E}-01$ & $2.78 \mathrm{E}-01$ & $3.1 \mathrm{E}+00$ & $4.13 \mathrm{E}-01$ & $3.8 \mathrm{E}+01$ \\
\hline $\mathrm{Mn}$ & $3.16 \mathrm{E}+00$ & $2.8 \mathrm{E}+00$ & $3.10 \mathrm{E}+00$ & $3.0 \mathrm{E}+00$ & $2.99 \mathrm{E}+00$ & 7.9E-01 \\
\hline $\mathrm{Na}$ & $1.40 \mathrm{E}+01$ & 9.3E-01 & NA & NA & $1.41 \mathrm{E}+01$ & 5.8E-01 \\
\hline $\mathrm{Ni}$ & $2.34 \mathrm{E}+00$ & $1.5 \mathrm{E}+00$ & $2.27 \mathrm{E}+00$ & $3.3 \mathrm{E}+00$ & $2.05 \mathrm{E}+00$ & $8.3 \mathrm{E}-01$ \\
\hline $\mathrm{Si}$ & $6.21 \mathrm{E}-01$ & $4.4 \mathrm{E}+01$ & $1.48 \mathrm{E}+00$ & $2.9 \mathrm{E}+00$ & NA & $\mathrm{NA}$ \\
\hline Th & $9.75 \mathrm{E}-01$ & $4.8 \mathrm{E}-01$ & 8.64E-01 & $5.4 \mathrm{E}+00$ & $6.89 \mathrm{E}-01$ & $1.3 \mathrm{E}+01$ \\
\hline $\mathrm{Ti}$ & $1.69 \mathrm{E}-02$ & $3.8 \mathrm{E}+00$ & $1.93 \mathrm{E}-02$ & $7.2 \mathrm{E}+00$ & $1.75 \mathrm{E}-02$ & $2.2 \mathrm{E}+00$ \\
\hline $\mathrm{U}$ & $5.42 \mathrm{E}+00$ & $2.3 \mathrm{E}+00$ & $5.19 \mathrm{E}+00$ & $3.6 \mathrm{E}+00$ & $5.14 \mathrm{E}+00$ & 7.9E-01 \\
\hline $\mathrm{Zr}$ & $1.23 \mathrm{E}-01$ & $1.5 \mathrm{E}+01$ & NA & NA & $2.33 \mathrm{E}-01$ & $1.2 \mathrm{E}+00$ \\
\hline
\end{tabular}

*All averages are based upon four replicate dissolutions and ICP-AES determinations except for $\mathrm{Al}$ from the AR digestions which is based upon two replicates. NA = Not Applicable. ${ }^{\#} \% \mathrm{RSD}$ is the percent relative standard deviation for the measurements. $\wedge$ Value not used in statistical comparison since calcium is a contaminant in the fusion reagents. 
Table 3-2 Statistical comparison of Aqua Regia, DWPF Cold Chem method and Sodium Peroxide/Hydroxide Fusion digestions of SB7a SRAT Receipt sludge. Digestions not having the same font, those that are not underlined or those separated with a less than sign are statistically different at the $5 \%$ significance level.

\begin{tabular}{|c|c|}
\hline Element & $\begin{array}{c}\text { Statistical } \\
\text { Comparisons }\end{array}$ \\
\hline $\mathbf{A l}$ & $\mathrm{AR}, \mathrm{CC}<\mathrm{PF}$ \\
\hline $\mathbf{B}$ & $\mathrm{NA}$ \\
\hline $\mathbf{C a}$ & $\mathrm{AR}, \mathrm{CC}$ \\
\hline $\mathbf{C r}$ & $\mathrm{AR}, \mathrm{CC}<\mathrm{PF}$ \\
\hline $\mathbf{C u}$ & $\mathrm{CC}<\mathrm{AR}, \mathrm{PF}$ \\
\hline $\mathbf{F e}$ & $\mathbf{C C}, \underline{\mathbf{P F}, \mathrm{AR}}$ \\
\hline $\mathbf{K}$ & $\mathrm{AR}<\mathrm{CC}<\mathrm{PF}$ \\
\hline $\mathbf{L i}$ & $\mathrm{NA}$ \\
\hline $\mathbf{M g}$ & $\mathrm{AR}, \mathrm{PF}, \mathrm{CC}$ \\
\hline $\mathbf{M n}$ & $\mathbf{C C}, \underline{\mathbf{P F}, \mathrm{AR}}$ \\
\hline $\mathbf{N a}$ & $\mathrm{AR}, \mathrm{CC}$ \\
\hline $\mathbf{N i}$ & $\mathrm{CC}<\mathrm{PF}, \mathrm{AR}$ \\
\hline $\mathbf{S i}$ & $\mathrm{NA}$ \\
\hline $\mathbf{T h}$ & $\mathrm{CC}<\mathrm{PF}, \mathrm{AR}$ \\
\hline $\mathbf{T i}$ & $\mathrm{AR}, \mathrm{CC}<\mathrm{PF}$ \\
\hline $\mathbf{U}$ & $\mathbf{C C}, \underline{\mathbf{P F}, \mathrm{AR}}$ \\
\hline $\mathbf{Z r}$ & $\mathrm{AR}<\mathrm{CC}$ \\
\hline
\end{tabular}

*Analysis is based on averages from four replicate dissolutions and ICP-AES determinations except for $\mathrm{Al}$ from the $\mathrm{AR}$ digestions, which is based on two measurements. NA = Not Applicable.

For the SRAT Receipt sample:

- The SRAT Receipt CC digestion solutions contained visible brown and white solids. The PF and AR digestion solutions did not contain visible solids.

- A statistical difference of means is observed for $\mathrm{Al}$ when comparing the PF results to the CC and AR results. The mean PF Al concentration is 7-8\% higher than the $\mathrm{CC}$ and AR means.

- A statistical difference of means is observed for $\mathrm{Cu}$ when the $\mathrm{CC}$ mean is compared to the PF and $\mathrm{AR}$ means. The $\mathrm{CC}$ results are $\sim 8 \%$ lower than the $\mathrm{AR}$ digestion and $\sim 13 \%$ lower than the PF mean.

- A statistical difference of means is observed for $\mathrm{Cr}$ when comparing the PF results to the CC and $\mathrm{AR}$ results. The mean $\mathrm{PF} \mathrm{Cr}$ concentration is $12 \%$ and $18 \%$ higher than the $\mathrm{CC}$ and $\mathrm{AR}$ means, respectively.

- A statistical difference of means is observed for Fe comparing the AR mean to the CC mean. The CC mean is $\sim 12 \%$ lower than the AR mean. There is no statistical difference between the $\mathrm{CC}$ and $\mathrm{PF}$ means although the PF mean is $\sim 9 \%$ higher than the $\mathrm{CC}$ mean. However, the brown visible solids in the digestions, indicate the $\mathrm{CC}$ method is not adequate for $\mathrm{Fe}$ determination.

- A statistical difference of means is noted for $\mathrm{K}$ when the three digestion methods are compared. The $\mathrm{PF}$ mean is $34 \%$ and $150 \%$ higher relative to the $\mathrm{AR}$ and $\mathrm{CC}$ means, respectively.

- A statistical difference of means is noted for $\mathrm{Mn}$ when comparing the $\mathrm{AR}$ and $\mathrm{CC}$ results. No statistical difference is noted between the $\mathrm{PF}$ and $\mathrm{CC}$ means. The relative difference between the $\mathrm{AR}$ mean and $\mathrm{CC}$ mean is $\sim 6 \%$. The relative difference between the $\mathrm{PF}$ and $\mathrm{CC}$ mean is 


\section{SRNL-STI-2011-00158, REVISION 0}

$\sim 4 \%$. The small relative difference indicates there is very little spread in the results even if there is a statistical difference.

- A statistical difference of means is observed for Ni when comparing the CC results to the PF and $\mathrm{AR}$ results. The mean $\mathrm{CC}$ Ni concentration is $10 \%$ and $13 \%$ lower than the $\mathrm{AR}$ and $\mathrm{PF}$ means, respectively.

- A statistical difference of means is observed for Th when comparing the $\mathrm{CC}$ results to the PF and $\mathrm{AR}$ results. The mean $\mathrm{CC}$ Th concentration is $23 \%$ and $34 \%$ lower than the $\mathrm{AR}$ and $\mathrm{PF}$ means, respectively.

- A statistical difference of means is observed for Ti when the $\mathrm{AR}$ and $\mathrm{CC}$ results are compared to the PF mean. The mean CC concentration is $\sim 9 \%$ lower than the PF mean and the AR mean is $\sim 13 \%$ lower. There is not a statistical difference between the means of AR and CC.

- A statistical difference of means is observed for $U$ when the AR mean is compared to the CC mean. The mean CC concentration is $\sim 5 \%$ lower than the AR mean. There is not a statistical difference between the means of PF and CC.

- It is expected that $\mathrm{Si}$ and $\mathrm{Zr}$ have statistical differences between the digestion types. The PF method is the only method that can be used at SRNL to obtain reliable Si values from sludge matrices. The CC method is the only method from which reliable $\mathrm{Zr}$ values can be obtained.

A statistical comparison of means from the results of digesting the glass standard ARG-1 was not performed. However, relative differences are listed in Tables 3-5-3-8. For the AR digestions, $\mathrm{Cu}$ was the only element with a relative difference greater than $10 \%$ compared to the known concentration of $\mathrm{Cu}$ in ARG-1. Si and $\mathrm{Zr}$ are not considered because the means of these elements are expected to be greater than $10 \%$ different. For the $\mathrm{PF}$ digestions, $\mathrm{Ca}, \mathrm{Cr}$ and $\mathrm{K}$ means were greater than $10 \%$ different than the known concentrations in ARG-1. Ca is a contaminant in the PF reagents. For the CC digestions, Ni was the only element which had a mean greater than $10 \%$ different than the known Ni concentration in ARG1. Low recovery of $\mathrm{Ni}$ in the SB7a samples and ARG-1 glass underscores the importance of using a different digestion method to determine Ni for SB7a. Low recovery of Ni has occurred before when method validation was carried out for SB6. ${ }^{4}$

Table 3-3 contains the elemental concentrations of the SB7a SRAT Product sample. 


\section{SRNL-STI-2011-00158, REVISION 0}

Table 3-3. Elemental concentrations of SB7a SRAT Product radioactive sludge slurry obtained from ICPAES analysis of Aqua Regia, DWPF Cold Chem method and Sodium Peroxide/Hydroxide Fusion digestions. Values are presented on a weight percent $(\mathrm{Wt} \%)$ total dried solids basis.

\begin{tabular}{|c|c|c|c|c|c|c|}
\hline $\begin{array}{c}\text { Digestion } \\
\text { Method } \rightarrow\end{array}$ & \multicolumn{2}{|c|}{ Aqua Regia } & \multicolumn{2}{c|}{$\begin{array}{c}\mathrm{Na}_{2} \mathrm{O}_{2} / \mathrm{NaOH} \\
\text { Fusion }\end{array}$} & \multicolumn{2}{c|}{ DWPF Cold Chem } \\
\hline Element & Avg Wt\%* & \%RSD & $\begin{array}{c}\text { Avg } \\
\text { Wt\%* }\end{array}$ & $\% \mathrm{RSD}^{\#}$ & Avg Wt\%* & $\% \mathrm{RSD}^{\#}$ \\
\hline $\mathrm{Al}$ & $8.42 \mathrm{E}+00$ & $2.0 \mathrm{E}+00$ & $8.92 \mathrm{E}+00$ & $1.2 \mathrm{E}+00$ & $8.06 \mathrm{E}+00$ & $2.8 \mathrm{E}+00$ \\
\hline $\mathrm{B}$ & $3.09 \mathrm{E}-03$ & $2.3 \mathrm{E}-01$ & $<2.50 \mathrm{E}-02$ & NA & NA & NA \\
\hline $\mathrm{Ca}$ & $4.66 \mathrm{E}-01$ & $1.2 \mathrm{E}+00$ & $6.17 \mathrm{E}-01$ & $2.6 \mathrm{E}+00$ & $5.73 \mathrm{E}-01^{\wedge}$ & $1.7 \mathrm{E}+01$ \\
\hline $\mathrm{Cr}$ & $4.09 \mathrm{E}-02$ & $1.7 \mathrm{E}+00$ & $3.78 \mathrm{E}-02$ & $2.5 \mathrm{E}+00$ & $3.94 \mathrm{E}-02$ & $1.2 \mathrm{E}+00$ \\
\hline $\mathrm{Cu}$ & $3.27 \mathrm{E}-02$ & $1.7 \mathrm{E}+00$ & $3.26 \mathrm{E}-02$ & $5.4 \mathrm{E}+00$ & $3.00 \mathrm{E}-02$ & $2.8 \mathrm{E}+00$ \\
\hline $\mathrm{Fe}$ & $1.11 \mathrm{E}+01$ & $1.7 \mathrm{E}+00$ & $1.10 \mathrm{E}+01$ & $1.7 \mathrm{E}+00$ & $1.03 \mathrm{E}+01$ & $1.5 \mathrm{E}+00$ \\
\hline $\mathrm{Li}$ & $2.64 \mathrm{E}-02$ & $1.3 \mathrm{E}+00$ & $<5.04 \mathrm{E}-02$ & NA & $<3.01 \mathrm{E}-02$ & NA \\
\hline $\mathrm{K}$ & $7.00 \mathrm{E}-02$ & $5.6 \mathrm{E}+00$ & $<2.33 \mathrm{E}-01$ & NA & $2.14 \mathrm{E}-01$ & $2.4 \mathrm{E}+01$ \\
\hline $\mathrm{Mg}$ & $2.13 \mathrm{E}-01$ & $1.3 \mathrm{E}+00$ & $2.14 \mathrm{E}-01$ & $1.4 \mathrm{E}+00$ & $3.46 \mathrm{E}-01$ & $2.6 \mathrm{E}+01$ \\
\hline $\mathrm{Mn}$ & $2.32 \mathrm{E}+00$ & $2.0 \mathrm{E}+00$ & $2.34 \mathrm{E}+00$ & $1.1 \mathrm{E}+00$ & $2.36 \mathrm{E}+00$ & $1.2 \mathrm{E}+00$ \\
\hline $\mathrm{Na}$ & $1.53 \mathrm{E}+01$ & $1.4 \mathrm{E}+00$ & NA & NA & $1.55 \mathrm{E}+01$ & $6.5 \mathrm{E}-01$ \\
\hline $\mathrm{Ni}$ & $2.02 \mathrm{E}+00$ & $1.3 \mathrm{E}+00$ & $1.98 \mathrm{E}+00$ & $1.7 \mathrm{E}+00$ & $1.78 \mathrm{E}+00$ & $1.1 \mathrm{E}+00$ \\
\hline $\mathrm{Si}$ & NA & NA & $1.21 \mathrm{E}+00$ & $1.4 \mathrm{E}+00$ & NA & NA \\
\hline $\mathrm{Th}$ & $8.64 \mathrm{E}-01$ & $1.2 \mathrm{E}+00$ & $9.27 \mathrm{E}-01$ & $3.7 \mathrm{E}+00$ & $4.32 \mathrm{E}-01$ & $2.5 \mathrm{E}+01$ \\
\hline $\mathrm{Ti}$ & $1.42 \mathrm{E}-02$ & $1.5 \mathrm{E}+00$ & $1.43 \mathrm{E}-02$ & $3.2 \mathrm{E}+00$ & $1.51 \mathrm{E}-02$ & $3.7 \mathrm{E}+00$ \\
\hline $\mathrm{U}$ & $4.49 \mathrm{E}+00$ & $7.6 \mathrm{E}-01$ & $4.45 \mathrm{E}+00$ & $2.1 \mathrm{E}+00$ & $4.50 \mathrm{E}+00$ & $9.4 \mathrm{E}-01$ \\
\hline $\mathrm{Zr}$ & $1.12 \mathrm{E}-01$ & $2.1 \mathrm{E}+01$ & NA & NA & $1.96 \mathrm{E}-01$ & $1.7 \mathrm{E}+00$ \\
\hline
\end{tabular}

*All averages are based upon four replicate dissolutions and ICP-AES determinations except for B which is based upon two replicates. $\mathrm{NA}=$ Not Applicable. ${ }^{\#} \% \mathrm{RSD}$ is the percent relative standard deviation for the measurements. ${ }^{\wedge}$ Value not used in statistical comparison since calcium is a contaminant in the fusion reagents.

A statistical comparison of means from SB7a SRAT product digestions is presented in Table 3-4. 


\section{SRNL-STI-2011-00158, REVISION 0}

Table 3-4. Statistical comparison of Aqua Regia, DWPF Cold Chem method and Sodium Peroxide/Hydroxide Fusion digestions of SB7a SRAT Product sludge. Digestions not having the same font, those that are not underlined or those separated with a less than sign are statistically different at the $\mathbf{5 \%}$ significance level.

\begin{tabular}{|c|c|}
\hline Element & $\begin{array}{c}\text { Statistical } \\
\text { Comparisons }\end{array}$ \\
\hline $\mathrm{Al}$ & $\mathrm{CC}<\mathrm{AR}<\mathrm{PF}$ \\
\hline $\mathrm{B}$ & $\mathrm{NA}$ \\
\hline $\mathrm{Ca}$ & $\mathrm{AR}, \mathrm{CC}$ \\
\hline $\mathrm{Cr}$ & $\mathrm{PF}<\mathrm{CC}<\mathrm{AR}$ \\
\hline $\mathrm{Cu}$ & $\mathrm{CC}<\mathrm{PF}, \mathrm{AR}$ \\
\hline $\mathrm{Fe}$ & $\mathrm{CC}<\mathrm{PF}, \mathrm{AR}$ \\
\hline $\mathrm{K}$ & $\mathrm{AR}<\mathrm{CC}$ \\
\hline $\mathrm{Li}$ & $\mathrm{NA}$ \\
\hline $\mathrm{Mg}$ & $\mathrm{AR}, \mathrm{PF},<\mathrm{CC}$ \\
\hline $\mathrm{Mn}$ & $\mathrm{AR}, \mathrm{PF}, \mathrm{CC}$ \\
\hline $\mathrm{Na}$ & $\mathrm{AR}, \mathrm{CC}$ \\
\hline $\mathrm{Ni}$ & $\mathrm{CC}<\mathrm{PF}, \mathrm{AR}$ \\
\hline $\mathrm{Si}$ & $\mathrm{NA}$ \\
\hline $\mathrm{Th}$ & $\mathrm{CC}<\mathrm{AR}, \mathrm{PF}$ \\
\hline $\mathrm{Ti}$ & $\mathrm{AR}, \mathbf{P F}, \mathrm{CC}$ \\
\hline $\mathrm{U}$ & $\mathrm{PF}, \mathrm{AR}, \mathrm{CC}$ \\
\hline $\mathrm{Zr}$ & $\mathrm{AR}<\mathrm{CC}$ \\
\hline
\end{tabular}

*All averages are based upon four replicate dissolutions and ICP-AES determinations. NA $=$ Not Applicable.

For the SRAT Product sample:

- The SRAT Product CC digestion solutions contained visible brown and white solids. The PF and AR digestion solutions did not contain visible solids.

- A statistical difference of means is observed for $\mathrm{Al}$ when comparing the results from the three digestions. The mean PF Al concentration is $\sim 10 \%$ higher than the $\mathrm{CC}$ mean and the $\mathrm{AR}$ mean is $\sim 4 \%$ higher than the $\mathrm{CC}$ mean.

- A statistical difference of means is observed for $\mathrm{Cr}$ when the three digestion methods are compared. The mean PF Cr concentration is 4-8\% lower than the CC and AR means. The small relative difference indicates there is very little spread in the results even if there is a statistical difference.

- A statistical difference of means is observed for $\mathrm{Cu}$ when the $\mathrm{CC}$ mean is compared to the PF and $\mathrm{AR}$ means. The mean $\mathrm{CC} \mathrm{Cu}$ concentration is $\sim 8 \%$ lower than the $\mathrm{PF}$ and $\mathrm{AR}$ means. The small relative difference with a statistical difference indicates a very small spread in the results for each digestion method.

- A statistical difference of means is observed for Fe comparing the $\mathrm{CC}$ mean to the $\mathrm{AR}$ and PF means. The $\mathrm{CC}$ mean is $\sim 7 \%$ lower than the $\mathrm{AR}$ and $\mathrm{PF}$ means.

- A statistical difference of means is observed for $\mathrm{Mg}$ comparing the $\mathrm{CC}$ mean to the $\mathrm{AR}$ and $\mathrm{PF}$ means. The AR and PF means are $\sim 47 \%$ lower than the $\mathrm{CC}$ mean. However, the large $\% \mathrm{RSD}$ associated with the $\mathrm{CC}$ measurements indicates the concentration in the diluted sample was very close to the ICP-AES detection limit and therefore it is the opinion of the author that the $\mathrm{CC}$ value, in this case, should not be used. No statistical difference was noted for $\mathrm{Mg}$ between the AR and PF means. 
SRNL-STI-2011-00158, REVISION 0

- A statistical difference of means is observed for Ni when comparing the $\mathrm{CC}$ results to the PF and AR results. The mean CC Ni concentration is $10 \%$ and $12 \%$ lower than the AR and PF means, respectively.

- A statistical difference of means is observed for Th when comparing the CC results to the PF and $\mathrm{AR}$ results. The mean $\mathrm{CC}$ Th concentration is $67 \%$ and $73 \%$ lower than the $\mathrm{AR}$ and $\mathrm{PF}$ means, respectively.

- A statistical difference of means is observed for Ti when the AR and CC results are compared. The mean $\mathrm{CC}$ concentration is $\sim 6 \%$ higher than the $\mathrm{AR}$ mean. There is not a statistical difference between the means of $A R$ and $P F$ and there is not a statistical difference between the means of PF and CC.

- It is expected that $\mathrm{Si}$ and $\mathrm{Zr}$ have statistical differences between the digestion types. The PF method is the only method that can be used at SRNL to obtain reliable Si values from sludge matrices. The CC method is the only method from which reliable $\mathrm{Zr}$ values can be obtained.

A statistical comparison of means from the results of digesting the glass standard ARG-1 was not performed. However, relative differences are listed in Tables 3-5 through table 3-8. For the AR digestions, $\mathrm{Cu}$ and $\mathrm{Ti}$ are elements having greater than $10 \%$ difference compared to the known concentration of $\mathrm{Cu}$ and $\mathrm{Ti}$ in ARG-1. Si and $\mathrm{Zr}$ are not considered because the means of these elements are expected to be greater than $10 \%$ different. For the $\mathrm{PF}$ digestions, $\mathrm{B}$ and $\mathrm{Ca}$ means were greater than $10 \%$ different than the known concentrations in ARG-1. Ca is a contaminant in the PF reagents. For the $\mathrm{CC}$ digestions, $\mathrm{Ca}$ and $\mathrm{Mg}$ were greater than $20 \%$ higher than the known concentrations in $\mathrm{ARG}-1$, the cause of this is not known for sure but based upon the \%RSDs, the concentration of these elements must be very close to the ICP-AES detection limit and $\mathrm{Ca}$ is a contaminant in the PF reagents.

Table 3-5 through Table 3-8 contain the ICP-AES measured weight percent elemental results from triplicate digestions of the ARG standard performed concurrently with the SB7a SRAT samples to determine if the dissolutions were complete and the resulting analyses accurate. Comparison to the known elemental weight percent in the ARG standard is also given in Tables 3-5 through 3-8. 
Table 3-5. Elemental concentrations of ARG standard from ICP-AES analysis of Aqua Regia, DWPF Cold Chem method and Sodium Peroxide/Hydroxide Fusion digestions performed concurrently with SB7a SRAT Receipt Sample. Values are presented on a weight percent (Wt\%) total solids basis.

\begin{tabular}{|c|c|c|c|c|}
\hline \multicolumn{5}{|c|}{ Aqua Regia* } \\
\hline Element & $\begin{array}{c}\text { Average } \\
\text { Wt } \%\end{array}$ & $\%$ RSD & Standard Value & $\begin{array}{c}\text { \%Difference } \\
\text { (Measured } v s \\
\text { Standard Value) }\end{array}$ \\
\hline Al & $2.44 \mathrm{E}+00$ & $3.4 \mathrm{E}+00$ & $2.50 \mathrm{E}+00$ & -2.4 \\
\hline $\mathrm{B}$ & $2.63 \mathrm{E}+00$ & $2.6 \mathrm{E}+00$ & $2.69 \mathrm{E}+00$ & -2.4 \\
\hline $\mathrm{Ca}$ & $1.02 \mathrm{E}+00$ & $3.0 \mathrm{E}+00$ & $1.02 \mathrm{E}+00$ & -0.2 \\
\hline $\mathrm{Cr}$ & $6.55 \mathrm{E}-02$ & $2.2 \mathrm{E}+00$ & $6.40 \mathrm{E}-02$ & 2.3 \\
\hline $\mathrm{Cu}$ & $2.54 \mathrm{E}-03$ & $2.9 \mathrm{E}+00$ & $3.00 \mathrm{E}-03$ & -15.4 \\
\hline $\mathrm{Fe}$ & $9.88 \mathrm{E}+00$ & $2.7 \mathrm{E}+00$ & $9.79 \mathrm{E}+00$ & 0.9 \\
\hline $\mathrm{K}$ & $2.25 \mathrm{E}+00$ & $2.0 \mathrm{E}+00$ & $2.26 \mathrm{E}+00$ & -0.3 \\
\hline $\mathrm{Li}$ & $1.47 \mathrm{E}+00$ & $2.6 \mathrm{E}+00$ & $1.49 \mathrm{E}+00$ & -1.1 \\
\hline $\mathrm{Mg}$ & $5.11 \mathrm{E}-01$ & $2.8 \mathrm{E}+00$ & $5.20 \mathrm{E}-01$ & -1.8 \\
\hline $\mathrm{Mn}$ & $1.45 \mathrm{E}+00$ & $2.6 \mathrm{E}+00$ & $1.46 \mathrm{E}+00$ & -0.5 \\
\hline $\mathrm{Na}$ & $8.55 \mathrm{E}+00$ & $2.6 \mathrm{E}+00$ & $8.52 \mathrm{E}+00$ & 0.4 \\
\hline $\mathrm{Ni}$ & $8.28 \mathrm{E}-01$ & $2.9 \mathrm{E}+00$ & $8.27 \mathrm{E}-01$ & 0.2 \\
\hline $\mathrm{Si}$ & $4.89 \mathrm{E}-01$ & $2.1 \mathrm{E}+01$ & $2.24 \mathrm{E}+01$ & -97.8 \\
\hline $\mathrm{Ti}$ & $6.43 \mathrm{E}-01$ & $3.7 \mathrm{E}+00$ & $6.90 \mathrm{E}-01$ & -6.8 \\
\hline $\mathrm{Zr}$ & $6.65 \mathrm{E}-02$ & $2.6 \mathrm{E}+00$ & $9.60 \mathrm{E}-02$ & -30.7 \\
\hline \multicolumn{5}{|c|}{ Sodium Peroxide/Hydroxide Fusion* } \\
\hline Element & $\begin{array}{c}\text { Average } \\
\text { Wt } \%\end{array}$ & $\%$ RSD & Standard Value & $\begin{array}{c}\text { \%Difference } \\
\text { (Measured vs } \\
\text { Standard Value) }\end{array}$ \\
\hline $\mathrm{Al}$ & $2.50 \mathrm{E}+00$ & $8.2 \mathrm{E}+00$ & $2.50 \mathrm{E}+00$ & -0.2 \\
\hline $\mathrm{B}$ & $2.50 \mathrm{E}+00$ & $7.4 \mathrm{E}+00$ & $2.69 \mathrm{E}+00$ & -7.1 \\
\hline $\mathrm{Ca}$ & $1.17 \mathrm{E}+00$ & $7.4 \mathrm{E}+00$ & $1.02 \mathrm{E}+00$ & 14.7 \\
\hline $\mathrm{Cr}$ & $7.48 \mathrm{E}-02$ & $1.5 \mathrm{E}+01$ & $6.40 \mathrm{E}-02$ & 16.8 \\
\hline $\mathrm{Cu}$ & $<1.07 \mathrm{E}-02$ & NA & $3.00 \mathrm{E}-03$ & NA \\
\hline $\mathrm{Fe}$ & $9.65 \mathrm{E}+00$ & $8.9 \mathrm{E}+00$ & $9.79 \mathrm{E}+00$ & -1.4 \\
\hline $\mathrm{K}$ & $2.58 \mathrm{E}+00$ & $6.6 \mathrm{E}+00$ & $2.26 \mathrm{E}+00$ & 13.9 \\
\hline $\mathrm{Li}$ & $1.40 \mathrm{E}+00$ & $8.3 \mathrm{E}+00$ & $1.49 \mathrm{E}+00$ & -6.0 \\
\hline $\mathrm{Mg}$ & $5.14 \mathrm{E}-01$ & $7.6 \mathrm{E}+00$ & $5.20 \mathrm{E}-01$ & -1.2 \\
\hline $\mathrm{Mn}$ & $1.40 \mathrm{E}+00$ & $1.1 \mathrm{E}+01$ & $1.46 \mathrm{E}+00$ & -4.5 \\
\hline $\mathrm{Na}$ & $\mathrm{NA}$ & $\mathrm{NA}$ & $8.52 \mathrm{E}+00$ & $\mathrm{NA}$ \\
\hline $\mathrm{Ni}$ & $7.91 \mathrm{E}-01$ & $8.3 \mathrm{E}+00$ & $8.27 \mathrm{E}-01$ & -4.4 \\
\hline $\mathrm{Si}$ & $2.23 \mathrm{E}+01$ & $3.2 \mathrm{E}+00$ & $2.24 \mathrm{E}+01$ & -0.4 \\
\hline $\mathrm{Ti}$ & $7.02 \mathrm{E}-01$ & $1.1 \mathrm{E}+01$ & $6.90 \mathrm{E}-01$ & 1.7 \\
\hline $\mathrm{Zr}$ & NA & $\mathrm{NA}$ & $9.60 \mathrm{E}-02$ & $\mathrm{NA}$ \\
\hline
\end{tabular}

*All averages are based upon three replicate dissolutions and ICP-AES determinations except for the PF results which are based upon two replicates. NA $=$ Not applicable. 
Table 3-6. Continuation of elemental concentrations of ARG standard from ICP-AES analysis of Aqua Regia, DWPF Cold Chem method and Sodium Peroxide/Hydroxide Fusion digestions performed concurrently with SB7a SRAT Receipt Sample. Values are presented on a weight percent (Wt\%) total solids basis.

\begin{tabular}{|c|c|c|c|c|}
\hline \multirow{2}{*}{ Element } & Average & \%RSD & Known Value & $\begin{array}{c}\text { \%Difference } \\
\text { Measured } \text { vs } \\
\text { Known Value) }\end{array}$ \\
\hline $\mathrm{Al}$ & & & & -5.6 \\
\hline $\mathrm{B}$ & $2.36 \mathrm{E}+00$ & $7.3 \mathrm{E}-01$ & $2.50 \mathrm{E}+00$ & NA \\
\hline $\mathrm{Ca}$ & $\mathrm{NA}$ & $\mathrm{NA}$ & $2.69 \mathrm{E}+00$ & 3.3 \\
\hline $\mathrm{Cr}$ & $1.05 \mathrm{E}+00$ & $5.5 \mathrm{E}-01$ & $1.02 \mathrm{E}+00$ & -0.2 \\
\hline $\mathrm{Cu}$ & $6.39 \mathrm{E}-02$ & $1.9 \mathrm{E}+00$ & $6.40 \mathrm{E}-02$ & NA \\
\hline $\mathrm{Fe}$ & $<6.48 \mathrm{E}-03$ & $\mathrm{NA}$ & $3.00 \mathrm{E}-03$ & -4.2 \\
\hline $\mathrm{K}$ & $9.38 \mathrm{E}+00$ & $3.4 \mathrm{E}-01$ & $9.79 \mathrm{E}+00$ & 0.3 \\
\hline $\mathrm{Li}$ & $2.27 \mathrm{E}+00$ & $1.8 \mathrm{E}+00$ & $2.26 \mathrm{E}+00$ & -0.9 \\
\hline $\mathrm{Mg}$ & $1.48 \mathrm{E}+00$ & $3.9 \mathrm{E}-01$ & $1.49 \mathrm{E}+00$ & -3.1 \\
\hline $\mathrm{Mn}$ & $5.04 \mathrm{E}-01$ & $5.2 \mathrm{E}-01$ & $5.20 \mathrm{E}-01$ & -4.1 \\
\hline $\mathrm{Na}$ & $1.40 \mathrm{E}+00$ & $1.5 \mathrm{E}-06$ & $1.46 \mathrm{E}+00$ & 1.2 \\
\hline $\mathrm{Ni}$ & $8.62 \mathrm{E}+00$ & $5.3 \mathrm{E}-01$ & $8.52 \mathrm{E}+00$ & -11.7 \\
\hline $\mathrm{Si}$ & $7.30 \mathrm{E}-01$ & $3.4 \mathrm{E}-01$ & $8.27 \mathrm{E}-01$ & $\mathrm{NA}$ \\
\hline $\mathrm{Zr}$ & $\mathrm{NA}$ & $\mathrm{NA}$ & $2.24 \mathrm{E}+01$ & -2.4 \\
\hline
\end{tabular}

*All averages are based upon three replicate dissolutions and ICP-AES determinations NA $=$ Not applicable. $<\mathrm{MDL}=$ less than minimum detection limit. 
Table 3-7. Elemental concentrations of ARG standard from ICP-AES analysis of Aqua Regia, DWPF Cold Chem method and Sodium Peroxide/Hydroxide Fusion digestions performed concurrently with SB7a SRAT Product sample. Values are presented on a weight percent $(\mathrm{Wt} \%)$ total solids basis.

\begin{tabular}{|c|c|c|c|c|}
\hline \multicolumn{5}{|c|}{ Aqua Regia* } \\
\hline Element & Average & $\%$ RSD & Standard Value & $\begin{array}{l}\text { \%Difference } \\
\text { (Measured } v s \\
\text { Standard Value) }\end{array}$ \\
\hline $\mathrm{Al}$ & $2.46 \mathrm{E}+00$ & $4.7 \mathrm{E}-01$ & $2.50 \mathrm{E}+00$ & -1.5 \\
\hline $\mathrm{B}$ & $2.62 \mathrm{E}+00$ & $8.8 \mathrm{E}-01$ & $2.69 \mathrm{E}+00$ & -2.5 \\
\hline $\mathrm{Ca}$ & $9.93 \mathrm{E}-01$ & $1.2 \mathrm{E}-01$ & $1.02 \mathrm{E}+00$ & -2.7 \\
\hline $\mathrm{Cr}$ & $6.43 \mathrm{E}-02$ & $1.6 \mathrm{E}+00$ & $6.40 \mathrm{E}-02$ & 0.4 \\
\hline $\mathrm{Cu}$ & $2.31 \mathrm{E}-03$ & $6.6 \mathrm{E}+00$ & $3.00 \mathrm{E}-03$ & -22.9 \\
\hline $\mathrm{Fe}$ & $9.80 \mathrm{E}+00$ & $1.8 \mathrm{E}-01$ & $9.79 \mathrm{E}+00$ & 0.1 \\
\hline $\mathrm{K}$ & $2.25 \mathrm{E}+00$ & $2.6 \mathrm{E}-01$ & $2.26 \mathrm{E}+00$ & -0.6 \\
\hline $\mathrm{Li}$ & $1.46 \mathrm{E}+00$ & $0.0 \mathrm{E}+00$ & $1.49 \mathrm{E}+00$ & -2.0 \\
\hline $\mathrm{Mg}$ & $5.02 \mathrm{E}-01$ & $4.1 \mathrm{E}-01$ & $5.20 \mathrm{E}-01$ & -3.5 \\
\hline $\mathrm{Mn}$ & $1.41 \mathrm{E}+00$ & $4.1 \mathrm{E}-01$ & $1.46 \mathrm{E}+00$ & -3.7 \\
\hline $\mathrm{Na}$ & $8.58 \mathrm{E}+00$ & $4.2 \mathrm{E}-01$ & $8.52 \mathrm{E}+00$ & 0.7 \\
\hline $\mathrm{Ni}$ & $8.48 \mathrm{E}-01$ & $2.5 \mathrm{E}-01$ & $8.27 \mathrm{E}-01$ & 2.6 \\
\hline $\mathrm{Si}$ & NA & NA & $2.24 \mathrm{E}+01$ & NA \\
\hline $\mathrm{Ti}$ & $5.93 \mathrm{E}-01$ & $1.5 \mathrm{E}+00$ & $6.90 \mathrm{E}-01$ & -14.0 \\
\hline $\mathrm{Zr}$ & $1.09 \mathrm{E}-02$ & $9.2 \mathrm{E}-01$ & $9.60 \mathrm{E}-02$ & -88.6 \\
\hline \multicolumn{5}{|c|}{ Sodium Peroxide/Hydroxide Fusion * } \\
\hline Element & Average & \%RSD & Known Value & $\begin{array}{c}\text { \%Difference } \\
\text { (Measured } v s \\
\text { Known Value) }\end{array}$ \\
\hline $\mathrm{Al}$ & $2.46 \mathrm{E}+00$ & $3.3 \mathrm{E}+00$ & $2.50 \mathrm{E}+00$ & -1.5 \\
\hline $\mathrm{B}$ & $2.41 \mathrm{E}+00$ & $2.7 \mathrm{E}+00$ & $2.69 \mathrm{E}+00$ & -10.3 \\
\hline $\mathrm{Ca}$ & $1.17 \mathrm{E}+00$ & $4.2 \mathrm{E}+00$ & $1.02 \mathrm{E}+00$ & 15.0 \\
\hline $\mathrm{Cr}$ & $6.60 \mathrm{E}-02$ & $4.0 \mathrm{E}+00$ & $6.40 \mathrm{E}-02$ & 3.2 \\
\hline $\mathrm{Cu}$ & $<1.17 \mathrm{E}-02$ & NA & $3.00 \mathrm{E}-03$ & NA \\
\hline $\mathrm{Fe}$ & $9.36 \mathrm{E}+00$ & $3.1 \mathrm{E}+00$ & $9.79 \mathrm{E}+00$ & -4.4 \\
\hline $\mathrm{K}$ & $2.30 \mathrm{E}+00$ & $4.1 \mathrm{E}+00$ & $2.26 \mathrm{E}+00$ & 1.8 \\
\hline $\mathrm{Li}$ & $1.47 \mathrm{E}+00$ & $2.7 \mathrm{E}+00$ & $1.49 \mathrm{E}+00$ & -1.3 \\
\hline $\mathrm{Mg}$ & 5.01E-01 & $3.0 \mathrm{E}+00$ & $5.20 \mathrm{E}-01$ & -3.7 \\
\hline $\mathrm{Mn}$ & $1.35 \mathrm{E}+00$ & $2.6 \mathrm{E}+00$ & $1.46 \mathrm{E}+00$ & -7.3 \\
\hline $\mathrm{Na}$ & NA & NA & $8.52 \mathrm{E}+00$ & NA \\
\hline $\mathrm{Ni}$ & 8.01E-01 & $4.1 \mathrm{E}+00$ & $8.27 \mathrm{E}-01$ & -3.1 \\
\hline $\mathrm{Si}$ & $2.16 \mathrm{E}+01$ & $1.6 \mathrm{E}+00$ & $2.24 \mathrm{E}+01$ & -3.7 \\
\hline $\mathrm{Ti}$ & $6.64 \mathrm{E}-01$ & $2.2 \mathrm{E}+00$ & $6.90 \mathrm{E}-01$ & -3.7 \\
\hline $\mathrm{Zr}$ & $2.46 \mathrm{E}+00$ & $3.3 \mathrm{E}+00$ & $9.60 \mathrm{E}-02$ & NA \\
\hline
\end{tabular}

*All averages are based upon three replicate dissolutions and ICP-AES determinations NA = Not applicable. 
Table 3-8. Continuation of elemental concentrations of ARG standard from ICP-AES analysis of Aqua Regia, DWPF Cold Chem method and Sodium Peroxide/Hydroxide Fusion digestions performed concurrently with SB7a SRAT Product sample. Values are presented on a weight percent $(\mathrm{Wt} \%)$ total solids basis.

\begin{tabular}{|c|c|c|c|c|}
\hline \multicolumn{5}{|c|}{ DWPF Cold Chem Method* } \\
\hline Element & Average & $\%$ RSD & Known Value & $\begin{array}{c}\text { \%Difference } \\
\text { (Measured } v s \\
\text { Known Value) }\end{array}$ \\
\hline $\mathrm{Al}$ & $2.45 \mathrm{E}+00$ & $3.6 \mathrm{E}+00$ & $2.50 \mathrm{E}+00$ & -2.0 \\
\hline B & NA & $\mathrm{NA}$ & $2.69 \mathrm{E}+00$ & NA \\
\hline $\mathrm{Ca}$ & $1.24 \mathrm{E}+00$ & $1.3 \mathrm{E}+01$ & $1.02 \mathrm{E}+00$ & 21.2 \\
\hline $\mathrm{Cr}$ & $6.45 \mathrm{E}-02$ & $6.3 \mathrm{E}-01$ & $6.40 \mathrm{E}-02$ & 0.8 \\
\hline $\mathrm{Cu}$ & $<6.23 \mathrm{E}-03$ & NA & $3.00 \mathrm{E}-03$ & NA \\
\hline $\mathrm{Fe}$ & $9.59 \mathrm{E}+00$ & $1.6 \mathrm{E}-01$ & $9.79 \mathrm{E}+00$ & -2.0 \\
\hline $\mathrm{K}$ & $2.26 \mathrm{E}+00$ & $1.3 \mathrm{E}+00$ & $2.26 \mathrm{E}+00$ & 0.1 \\
\hline $\mathrm{Li}$ & $1.49 \mathrm{E}+00$ & $6.7 \mathrm{E}-01$ & $1.49 \mathrm{E}+00$ & 0.0 \\
\hline $\mathrm{Mg}$ & $6.66 \mathrm{E}-01$ & $2.0 \mathrm{E}+01$ & $5.20 \mathrm{E}-01$ & 28.1 \\
\hline $\mathrm{Mn}$ & $1.43 \mathrm{E}+00$ & $0.0 \mathrm{E}+00$ & $1.46 \mathrm{E}+00$ & -2.1 \\
\hline $\mathrm{Na}$ & $8.72 \mathrm{E}+00$ & $2.3 \mathrm{E}-01$ & $8.52 \mathrm{E}+00$ & 2.3 \\
\hline $\mathrm{Ni}$ & $7.49 \mathrm{E}-01$ & $4.3 \mathrm{E}-01$ & $8.27 \mathrm{E}-01$ & -9.5 \\
\hline $\mathrm{Si}$ & NA & NA & $2.24 \mathrm{E}+01$ & $\mathrm{NA}$ \\
\hline $\mathrm{Ti}$ & $6.84 \mathrm{E}-01$ & $2.2 \mathrm{E}-01$ & $6.90 \mathrm{E}-01$ & -0.9 \\
\hline $\mathrm{Zr}$ & $9.67 \mathrm{E}-02$ & $5.1 \mathrm{E}-01$ & $9.60 \mathrm{E}-02$ & 0.8 \\
\hline
\end{tabular}

*All averages are based upon three replicate dissolutions and ICP-AES determinations NA $=$ Not applicable. $<\mathrm{MDL}=$ less than minimum detection limit.

Good recoveries were observed for most elements of significant weight percent in the ARG standards. There are a few anomalies but based upon the \%RSDs some of these elements were near the ICP-AES detection limit. Upon review of the SRAT Receipt, Product and ARG data it is evident that not all of the digestion issues seen with the radioactive sample are mirrored with the ARG standard. For instance, the Fe in the ARG appears to dissolve well in each digestion method as well as Al. The SRAT Receipt and SRAT product have $\sim 4 \mathrm{wt} \%$ more Fe than the ARG standard and the one and one-half hour time frame allotted for the digestion does not appear to be sufficient for dissolving all of the Fe. SB7a also contains some HM waste and the different phases of aluminum species present SRAT in the sludge slurry (boehmite and gibbsite among others) have varying solubility in the acid matrices. The Ni concentration measured in CC digestions of the ARG standards are consistently lower than the known concentration and the $\mathrm{CC}$ measured Ni concentrations are also lower than the PF and AR digestions of the SRAT Receipt/SRAT Product. Ni recovery in the ARG standards could be improved with the addition of $\mathrm{HCl}$ and Fe dissolution in the SRAT Receipt/SRAT Product could be improved with the addition of $\mathrm{HCl}$ but this is not an option for the DWPF. 


\subsection{CONCLUSIONS}

The results presented in this report document potential problems with the DWPF CC method and the accuracy of this digestion for certain elements contained in SB7a. Al, Fe, Ni, Mn and Th should be determined with an alternate digestion method such as the PF method or in some cases in conjunction with the $\mathrm{CC}$ method, which may be more suitable for $\mathrm{Ni}$ and $\mathrm{Mn}$. A statistical difference for other elements was seen as well but that does not mean that the DWPF should seek an alternate method for all elements having a statistical difference between digestion methods especially when the relative percent difference between the digestions is small. It is beyond the scope of this report to determine how accurate the data needs to be to stay within the glass processing parameters for SB7a. 
SRNL-STI-2011-00158, REVISION 0

This page intentionally left blank 


\section{SRNL-STI-2011-00158, REVISION 0}

\subsection{RECOMMENDATIONS}

The following recommendations are based upon results in this report:

- A statistically significant difference in the means (at the 5\% significance level) was observed for $\mathrm{Al}, \mathrm{Cr}, \mathrm{Cu}, \mathrm{Fe}, \mathrm{K}, \mathrm{Mn}, \mathrm{Ni}$, Ti, and Th for SB7a for the SRAT Receipt or SRAT Product samples or both. The relative difference of $10 \%$ or greater for $\mathrm{Fe}$ and $\mathrm{Ni}$ in the $\mathrm{CC}$ digestions versus the $\mathrm{AR}$ and PF digestions may be a potential issue and therefore needs to be evaluated by the DWPF for its impact. Although $\mathrm{K}$ is a minor element, large relative differences are noted in this report between the different digestions and the DWPF should also monitor the $\mathrm{K}$ concentration. $\mathrm{Al}, \mathrm{Fe}$, $\mathrm{Ni}$ and Th should be analyzed by the peroxide fusion method for SB7a. Mn can be measured using either the $\mathrm{CC}$ of PF method but monitored closely and the highest Mn concentration between the two digestions should be used.

- A dissolution study should be performed on the SB7a WAPS sample by SRNL which consists of the final composition of the sludge (the SB7a Blend) to determine if the $\mathrm{Fe}, \mathrm{Mn}$, and $\mathrm{Ni}$ concentrations are consistently low in the $\mathrm{CC}$ digestions versus the $\mathrm{AR}$ and $\mathrm{PF}$ methods for $\mathrm{SB} 7 \mathrm{a}$ given the blending that will occur with SB7a.

- The DWPF CC method was originally developed to be used for SME analyses. Given continuous visual observations of solids in the CC digestions both at SRNL and DWPF, potential issues with accurate $\mathrm{Al}$ measurements when processing HM waste, and the results in this report, SRNL recommends that the DWPF consider a different digestion scheme that relieves some of these issues.

- The results of this study need to be assessed against the glass processing control algorithms of the DWPF to determine the potential impact of any statistical difference of the means between elements. Specifically, the DWPF lab should investigate if comparisons between the elemental concentrations of the SME product (adjusted for frit addition) obtained by the mixed acid and peroxide fusion digestion and the SRAT Receipt and SRAT Product elemental concentrations obtained via the DWPF CC method provide insight into the adequacy of the CC method for analysis of the SRAT Product. It is beyond the scope of this report to determine how accurate the data needs to be to stay within the glass processing parameters for SB7a. If a consistent difference in elemental concentrations is revealed, another type of digestion (i.e. sodium peroxide/hydroxide fusion) should be used to determine the concentration of the element in question. Particular emphasis should be placed on monitoring $\mathrm{Al}, \mathrm{Fe}, \mathrm{K}, \mathrm{Mn}, \mathrm{Ni}$ and $\mathrm{Th}$ concentrations in SB7a. 
SRNL-STI-2011-00158, REVISION 0

This page intentionally left blank 


\subsection{REFERENCES}

1. C.J. Coleman, "Alkali Fusion Dissolutions of Sludge and Glass for Elemental and Anion Analysis", ADS Procedure ADS-2502, Rev. 6.

2. C.J. Coleman, "Aqua Regia Dissolution of Sludge for Elemental Analysis", ADS Procedure ADS-2226, Rev. 7.

3. JMP Statistical Discovery Software v 7.0.2; SAS Institute Inc., Cary, NC, 2008.

4. C.J. Coleman, F.M. Pennebaker, B.H. Burch and D.R. Click, "Evaluation of the DWPF Cold Chem Dissolution Method with DWPF Sludge Batch 3 Simulant", WSRC-TR-0200496, Rev. 0. See also D.R. Click, "Evaluation of the DWPF Cold Chem Dissolution Method with Tank 7 and Tank 51 Radioactive Sludges", WSRC-TR-2003-00580. D.R. Click, C.J. Coleman, K.E. Zeigler and T.B. Edwards, "Sludge Batch Four (4) Defense Waste Processing Facility (DWPF) Process Analytical Method Verification", WSRCSTI-2006-00025 Rev. 0. D. R. Click, T. B. Edwards, and M. A. Jones. "Verification of the Defense Waste Processing Facility's (DWPF) process digestion method for the Sludge Batch 6 qualification sample", WSRC-STI-2010-00259 Rev. 0. 
SRNL-STI-2011-00158, REVISION 0

This page intentionally left blank 


\subsection{ACKNOWLEDGEMENTS}

The authors would like to acknowledge Jane Howard, Monica Jenkins and Rita Sullivan. 
SRNL-STI-2011-00158, REVISION 0

This page intentionally left blank 
SRNL-STI-2011-00158, REVISION 0

\subsection{APPENDIX A. SUPPORTING INFORMATION}


g士

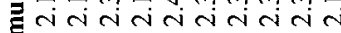
恶

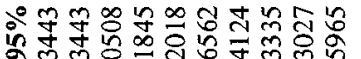

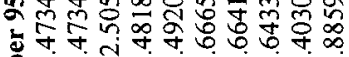

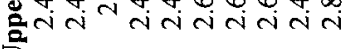

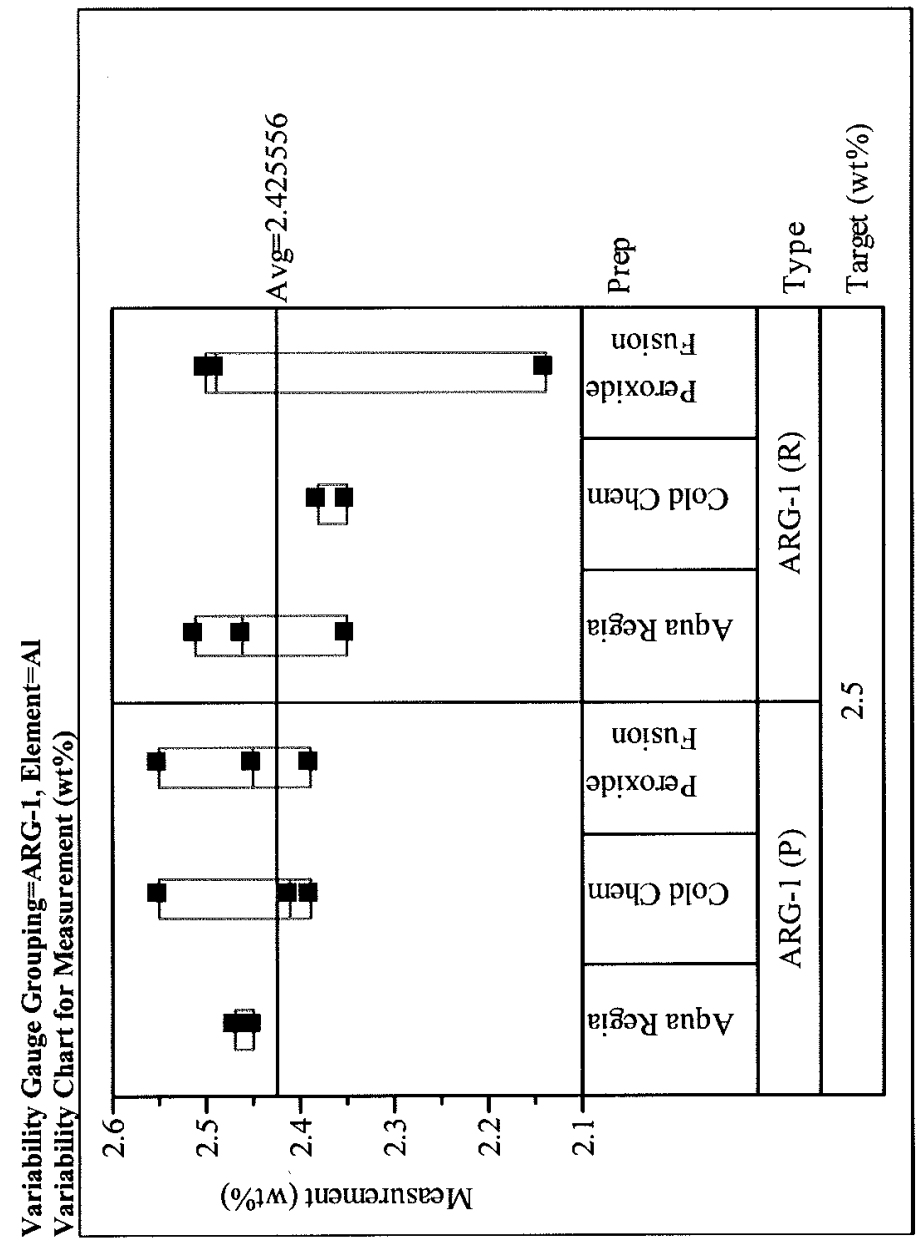

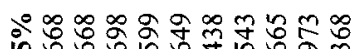

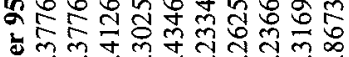
वरतaranan-

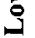

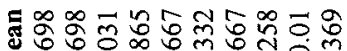

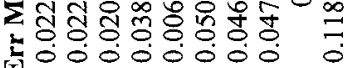
至

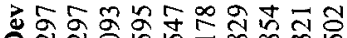

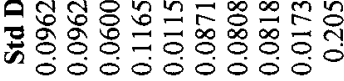

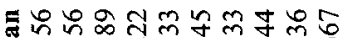

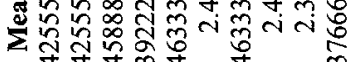

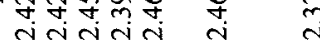
写

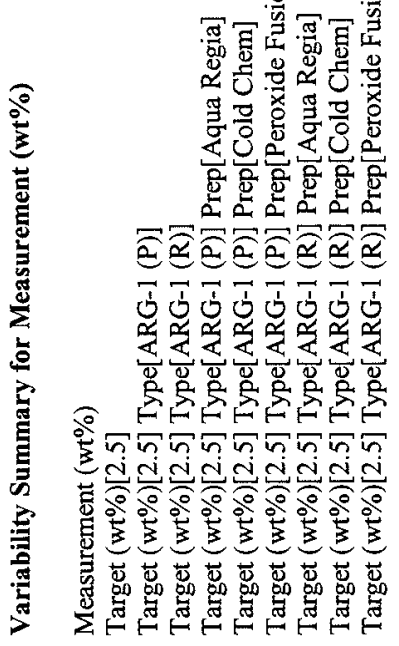



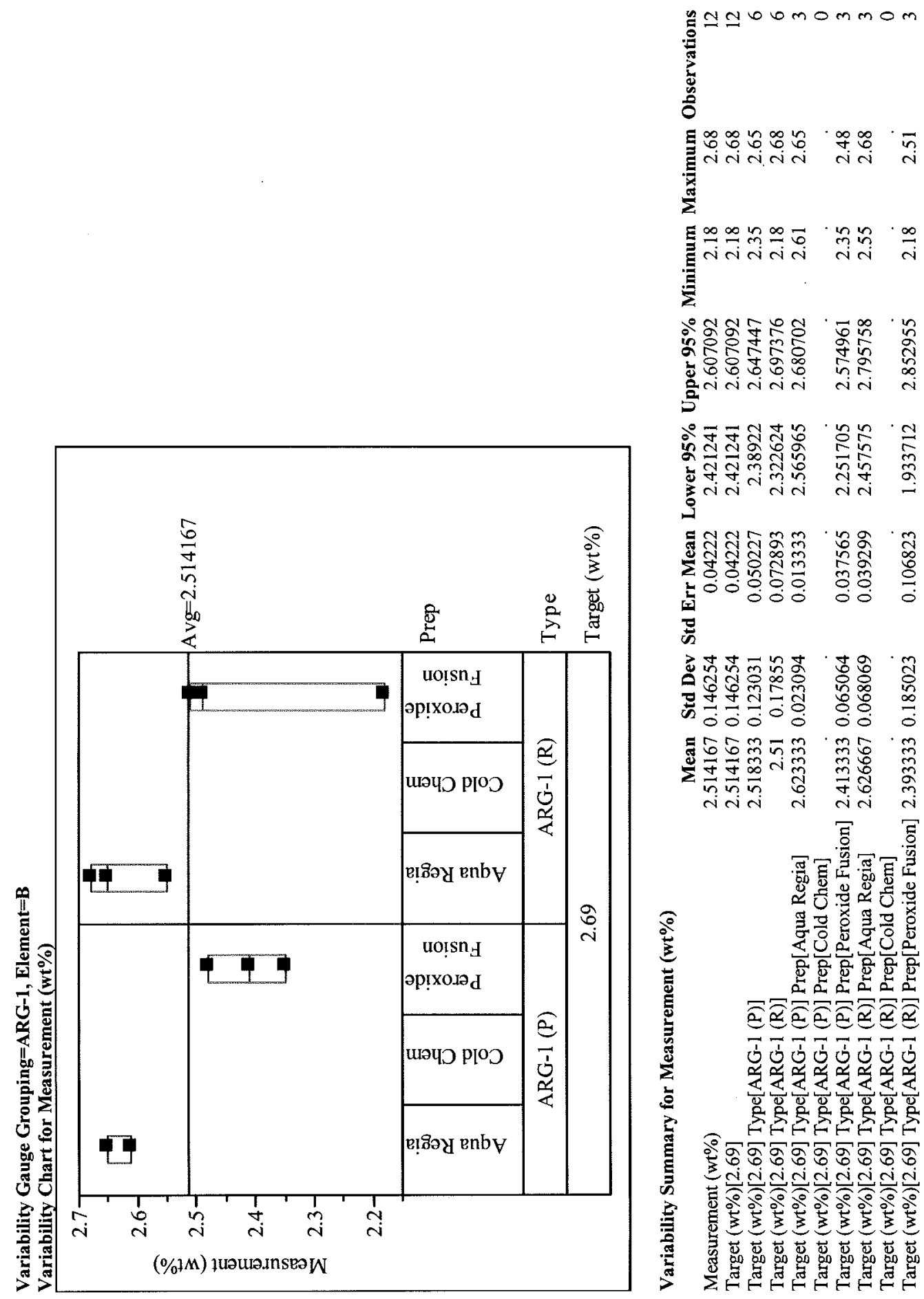

m

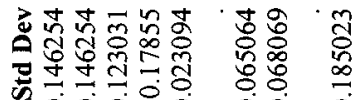
का

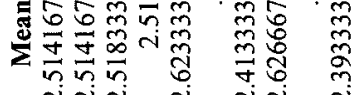
तलंत त लंत

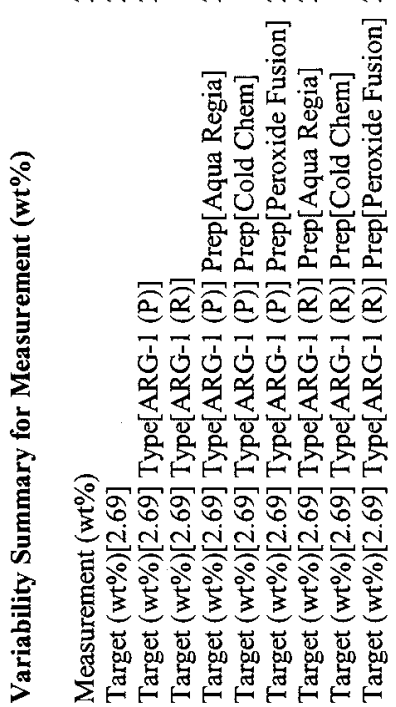




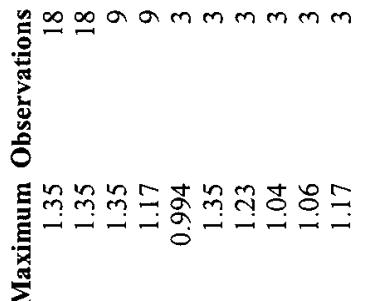

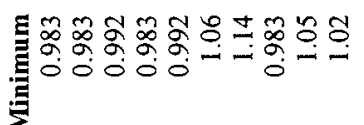

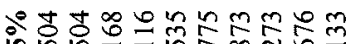

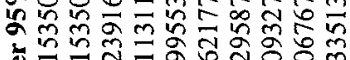
๘气 5

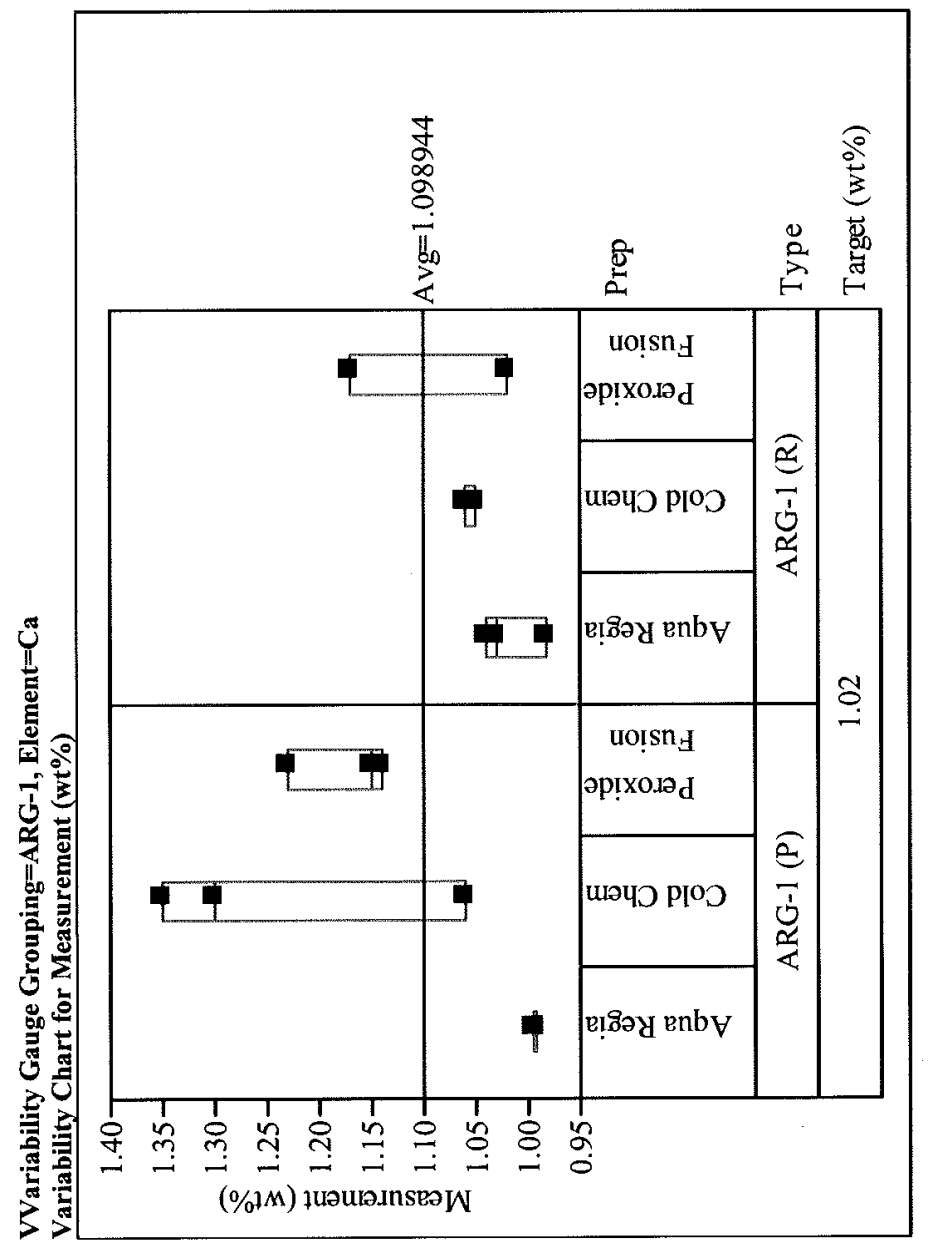

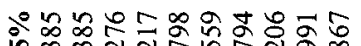

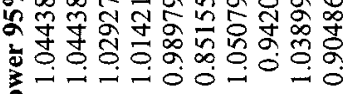

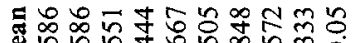

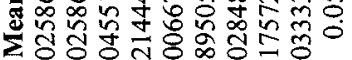
to 要

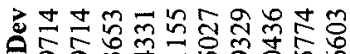

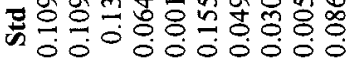
击击

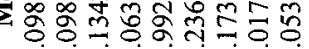

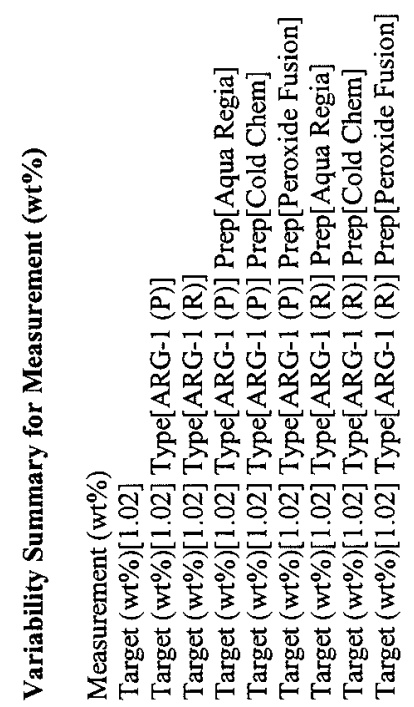



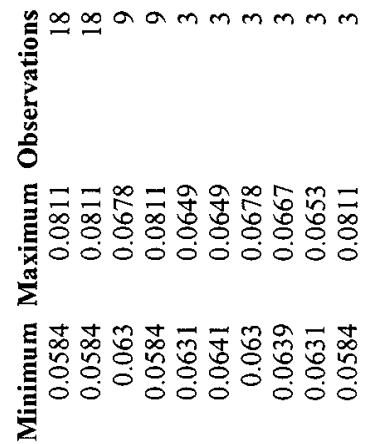

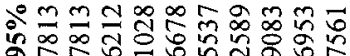



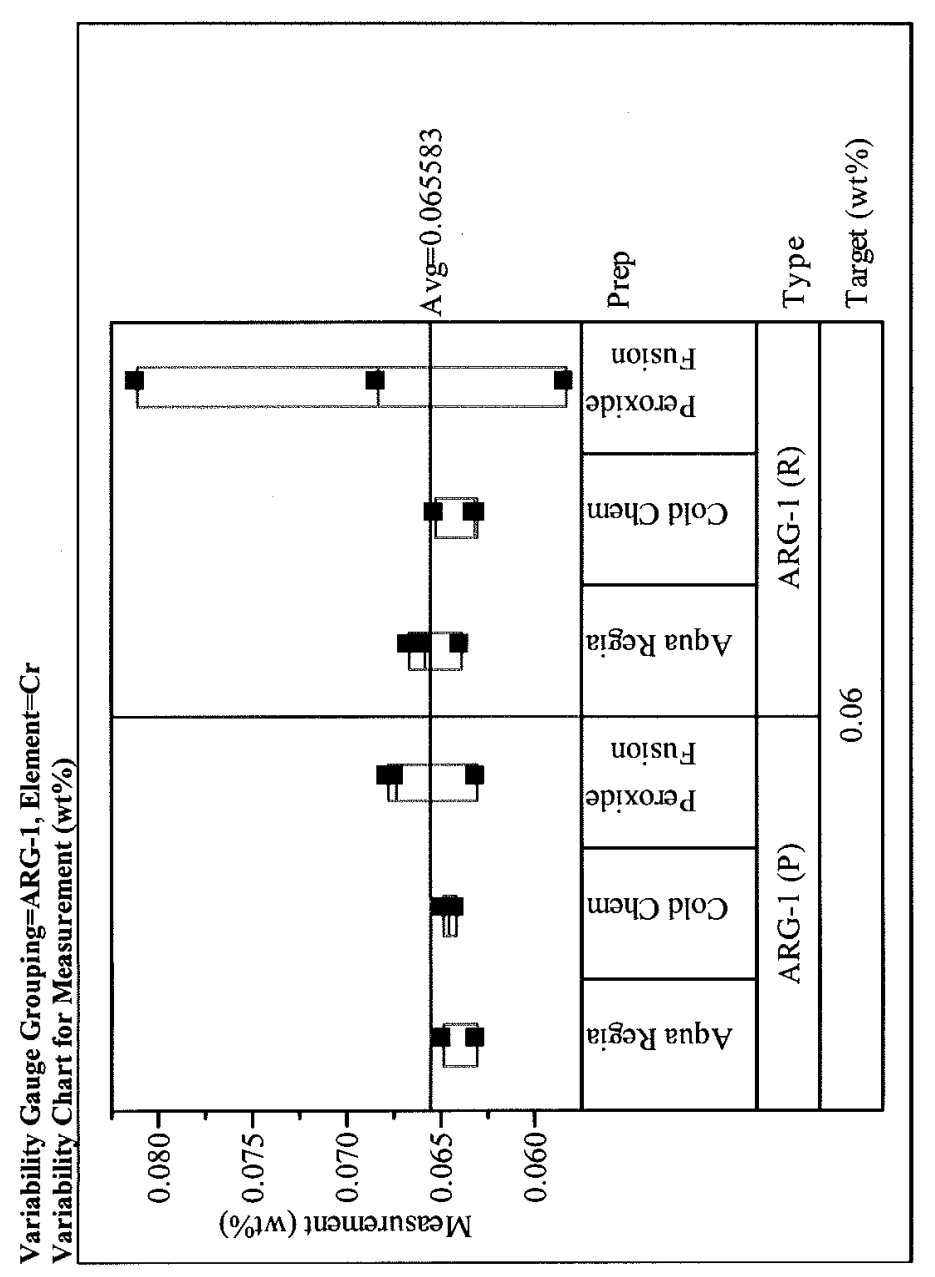

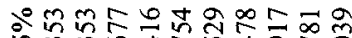
\% 䆑0000000000

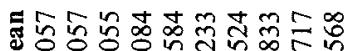

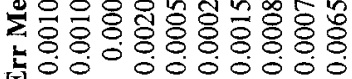
要

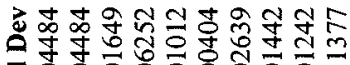

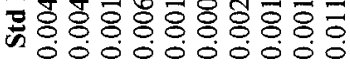

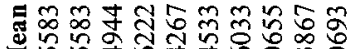

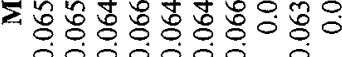

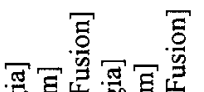
50 它它

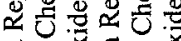

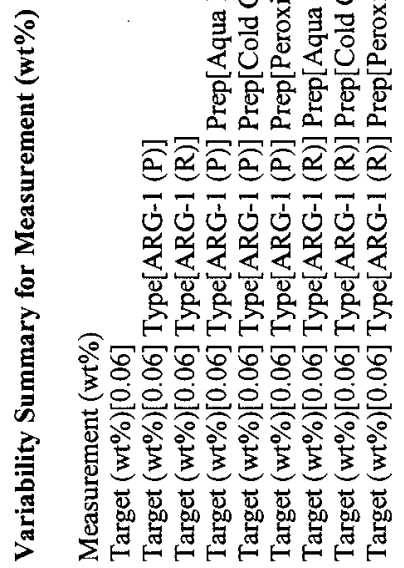


ชิ 高出

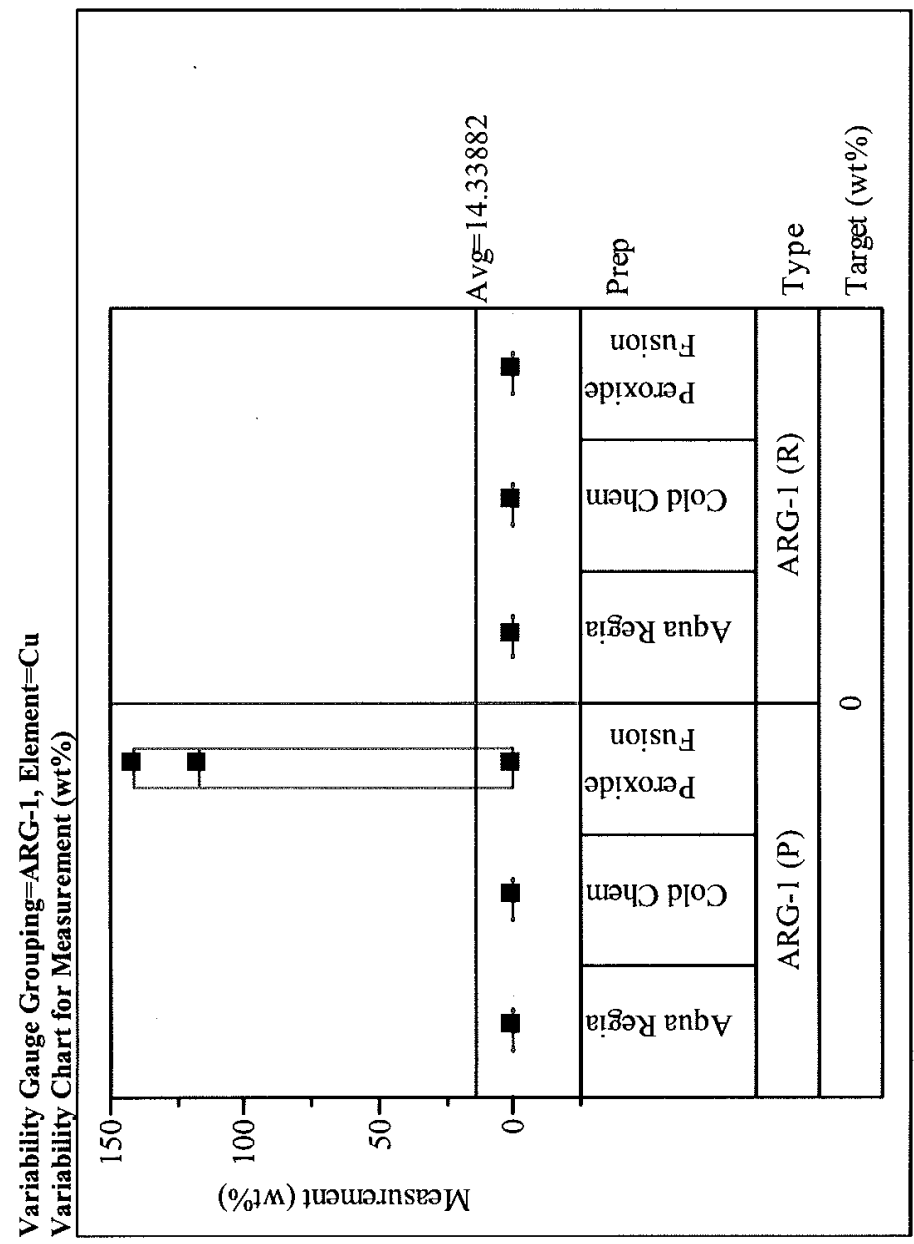

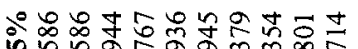

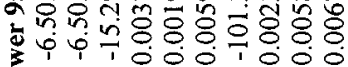
I

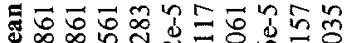

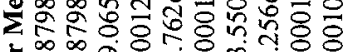

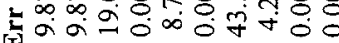
要

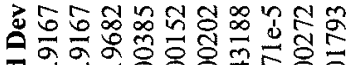

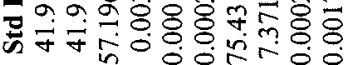

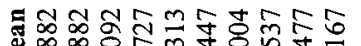

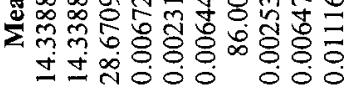

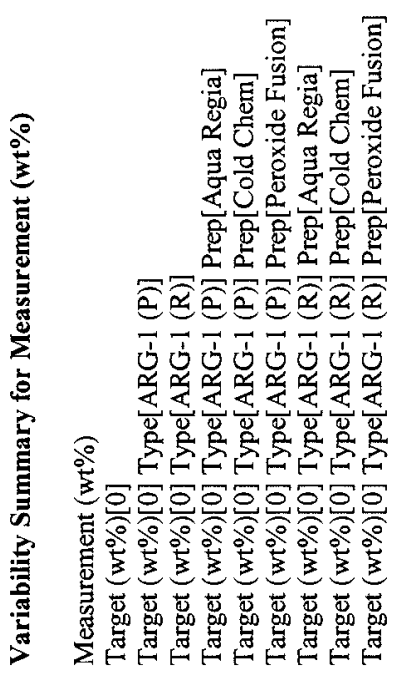




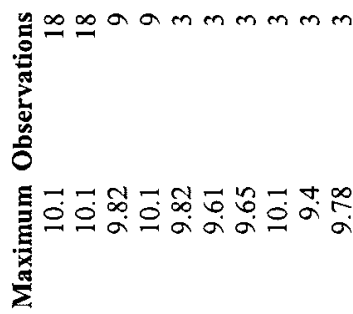

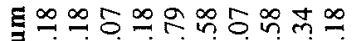

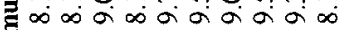
竞

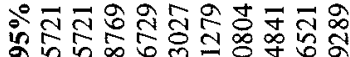

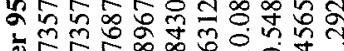

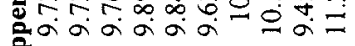
5

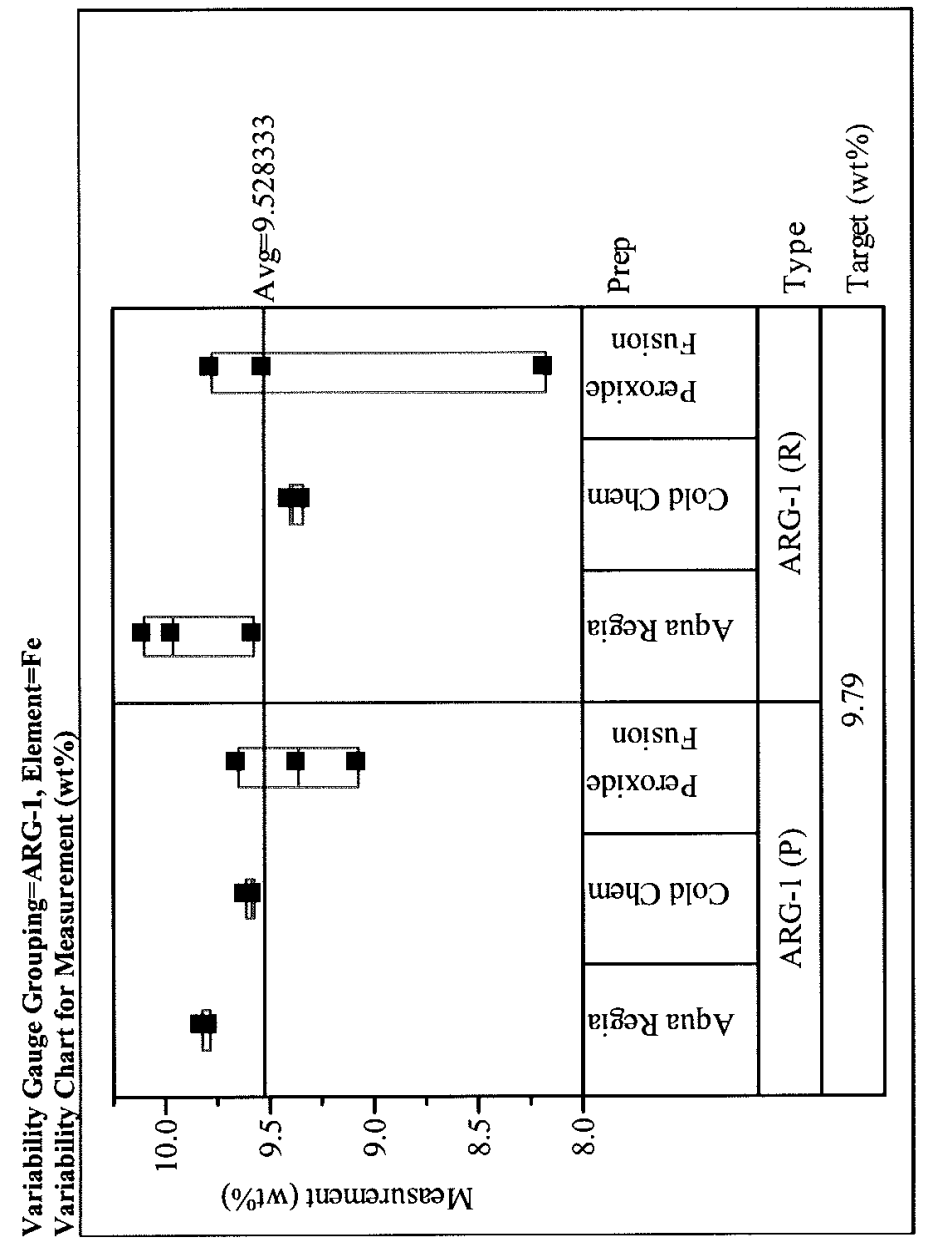

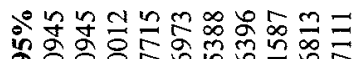

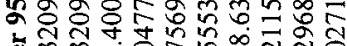

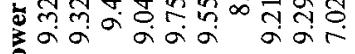
空

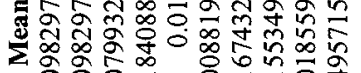

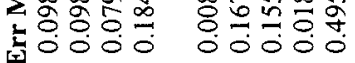
क ว

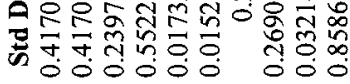

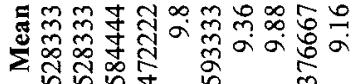

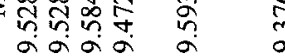

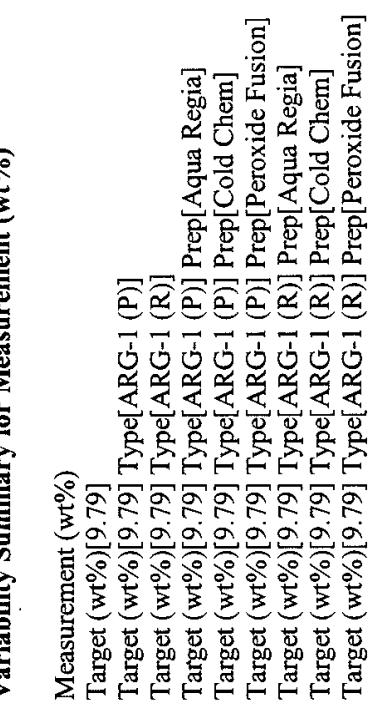


O

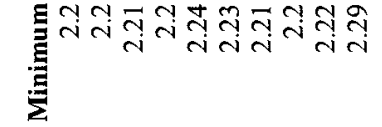

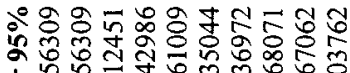

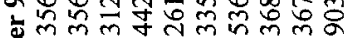

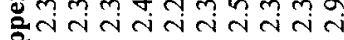
5

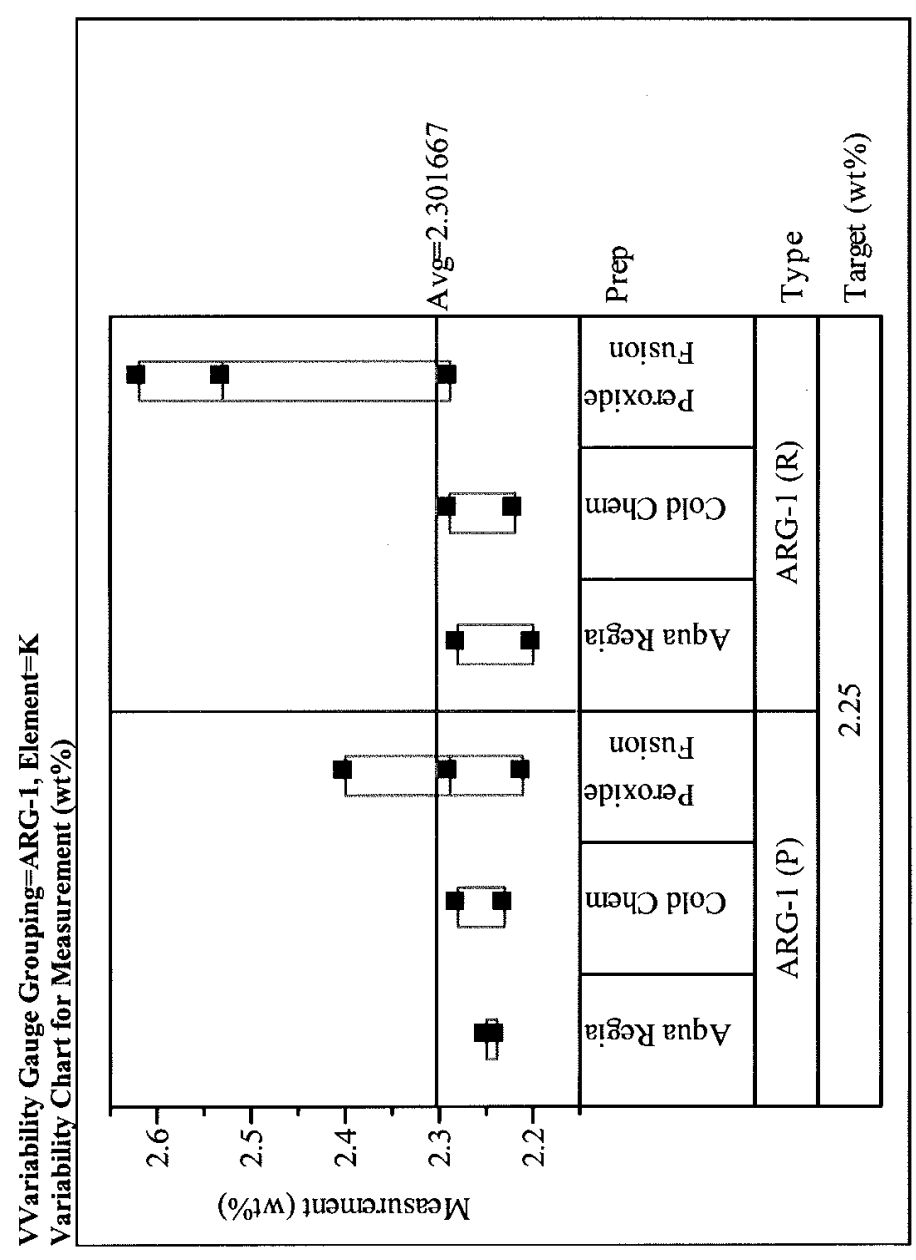

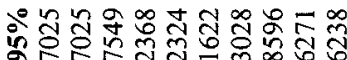

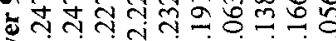

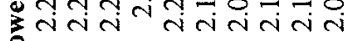

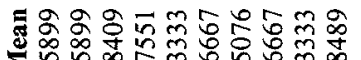
정셩ㅎㅇㅇㅇㅇㅇㅇㅇㅇㅇㅇ

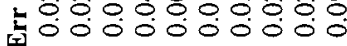
in

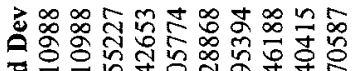

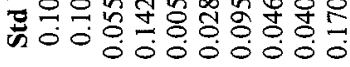

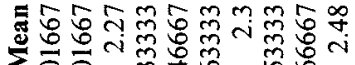

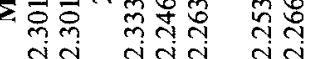
官 官

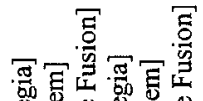

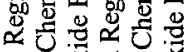

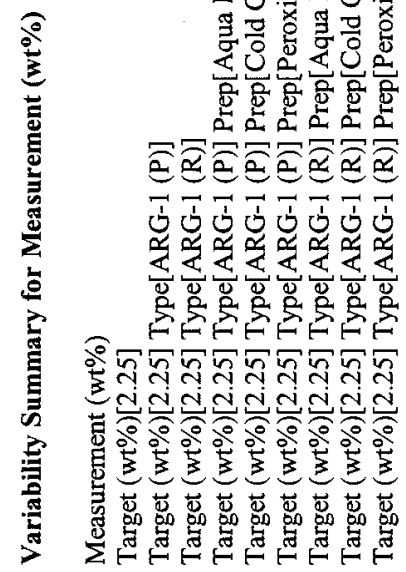


空

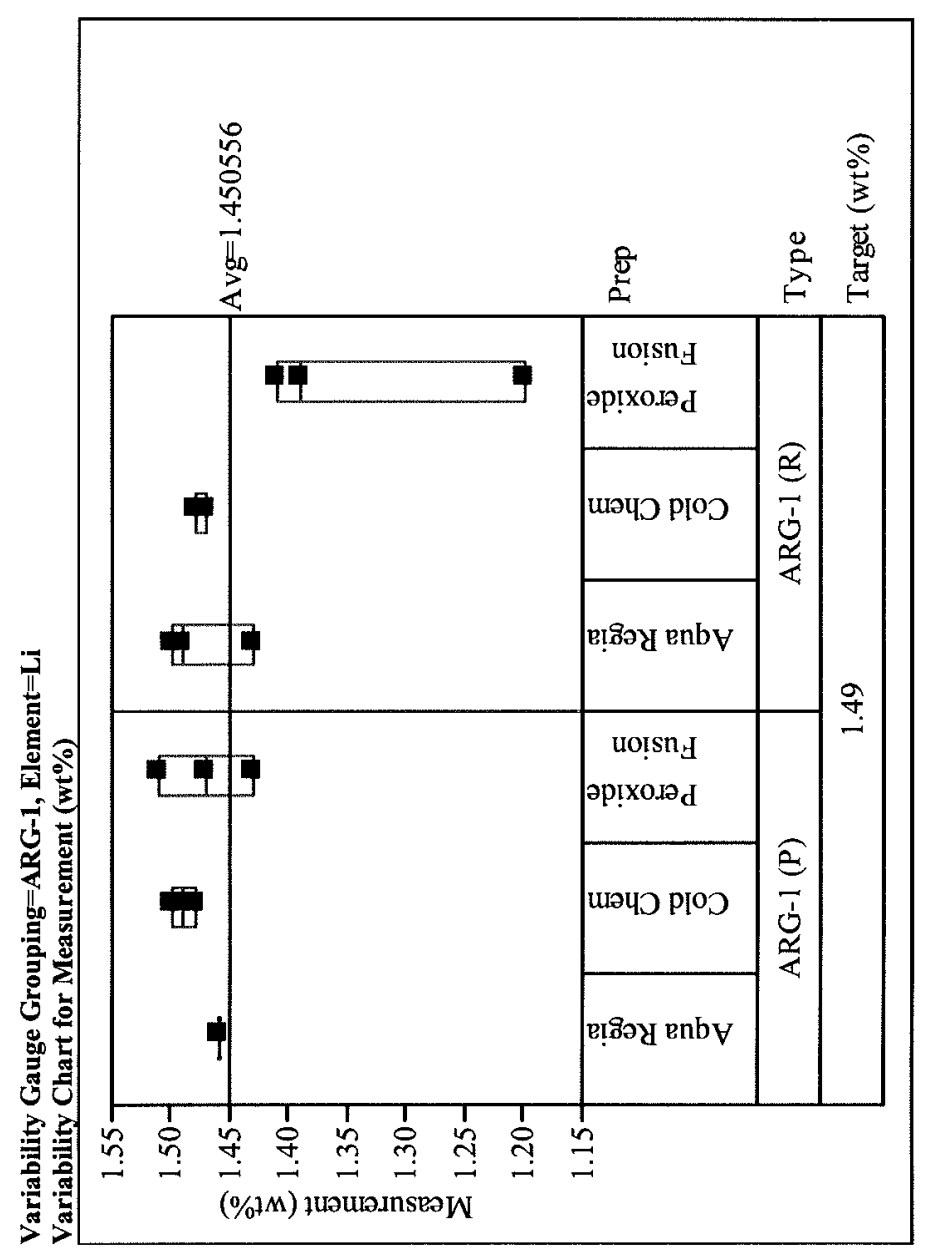

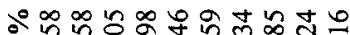

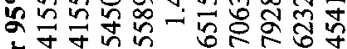

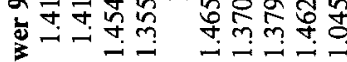
है

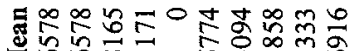

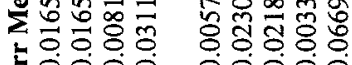

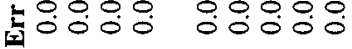
紊

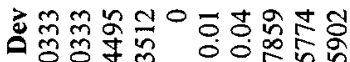

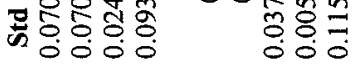

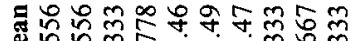

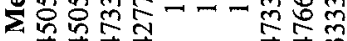
寸守守打

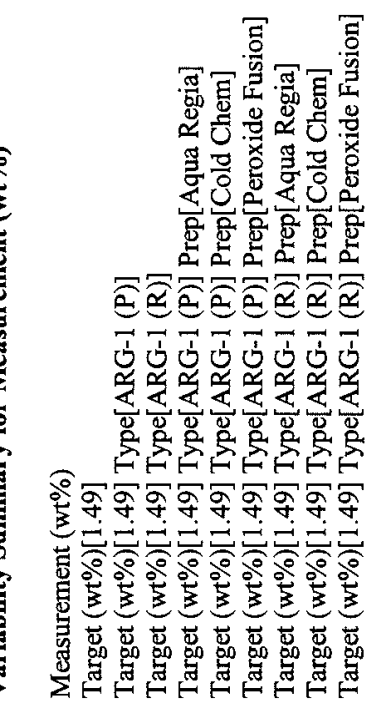



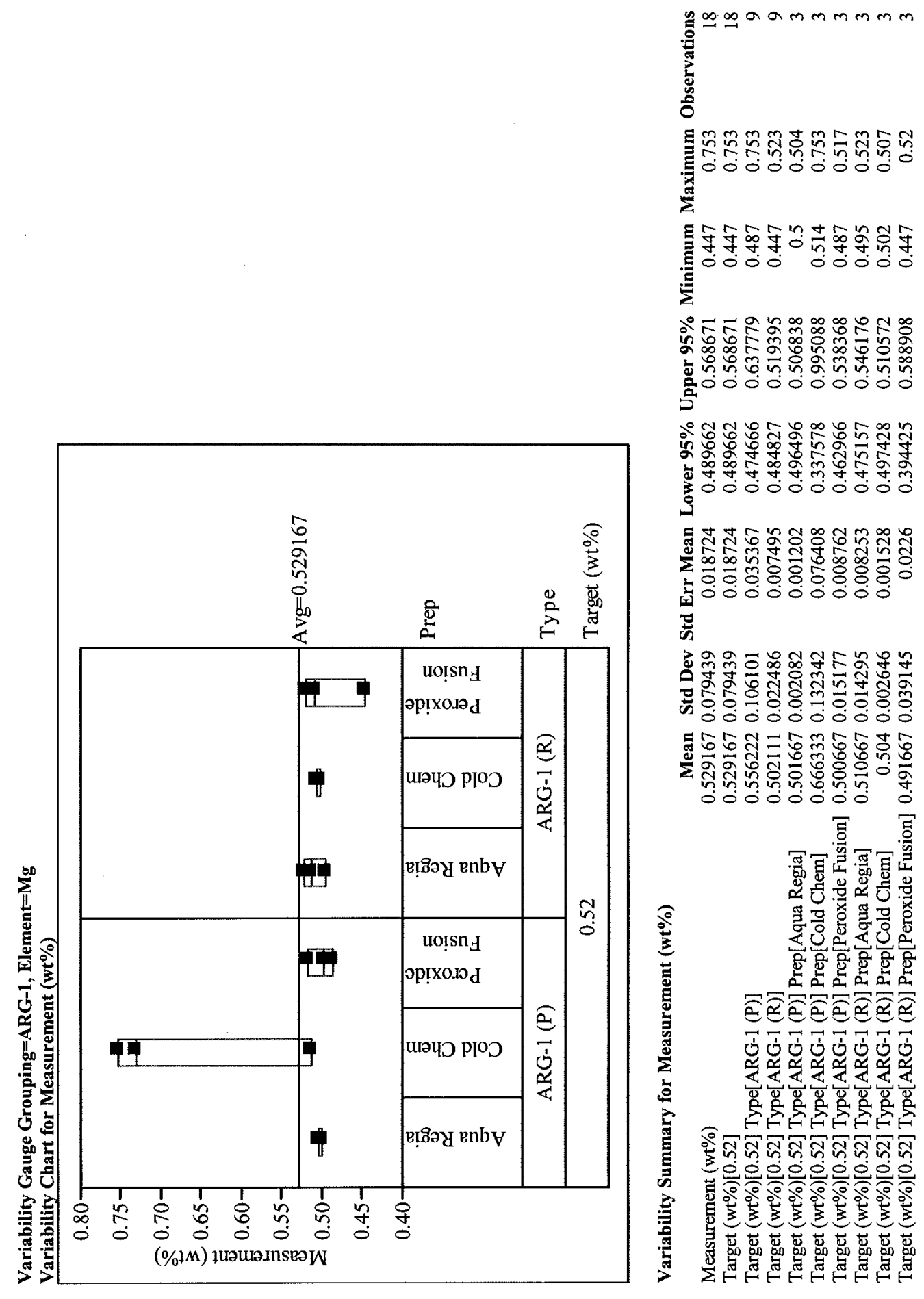

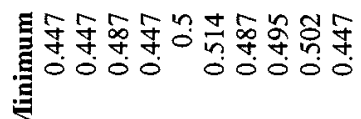

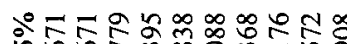

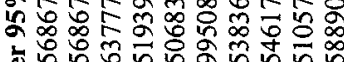

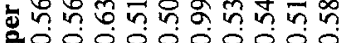
$\stackrel{5}{b}$

융ํㅇํํㅇํㅇํำ

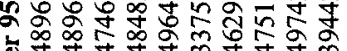

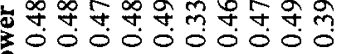
s

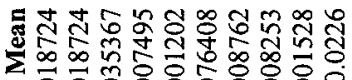

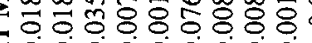

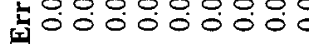
혼

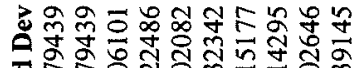

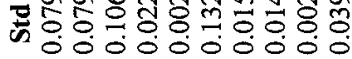

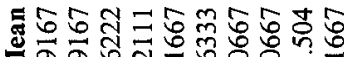

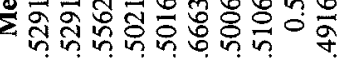
00000000

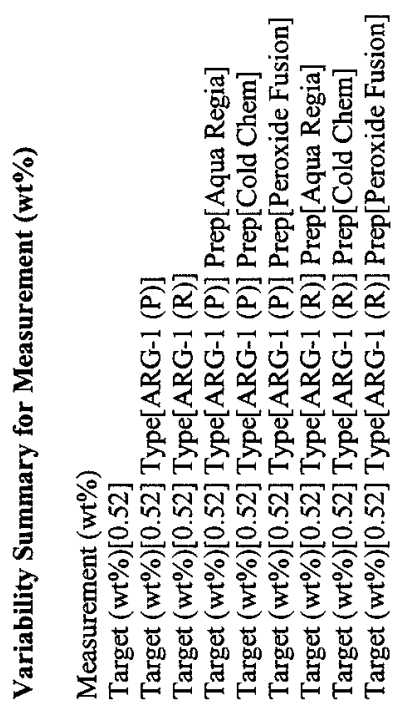



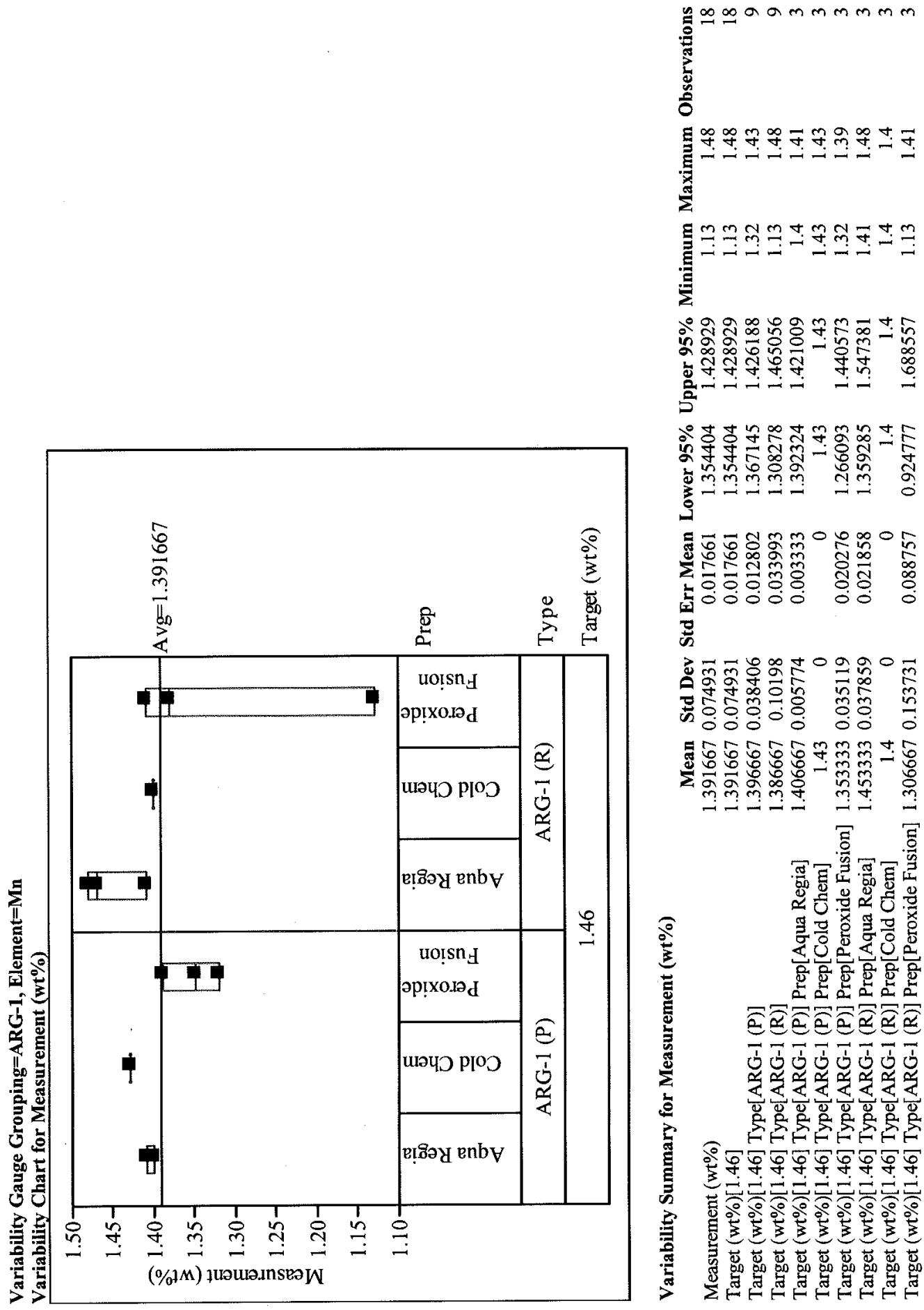

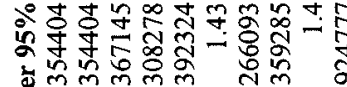

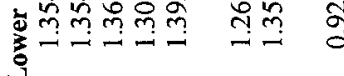

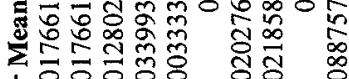

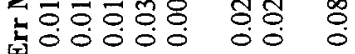

焉

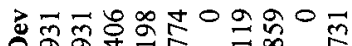

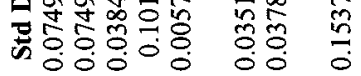

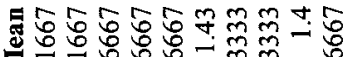

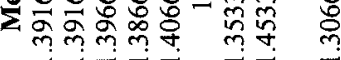

- -1 -

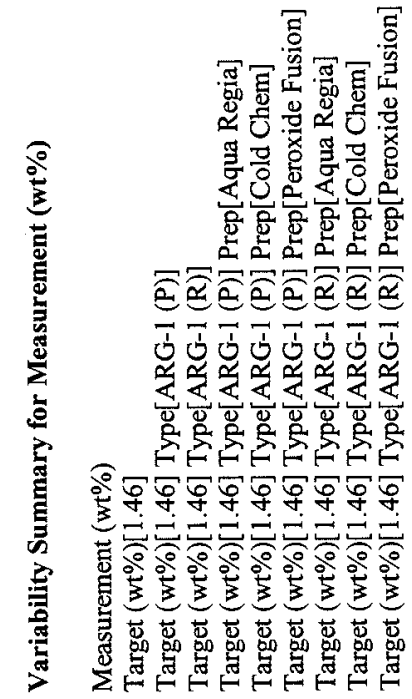




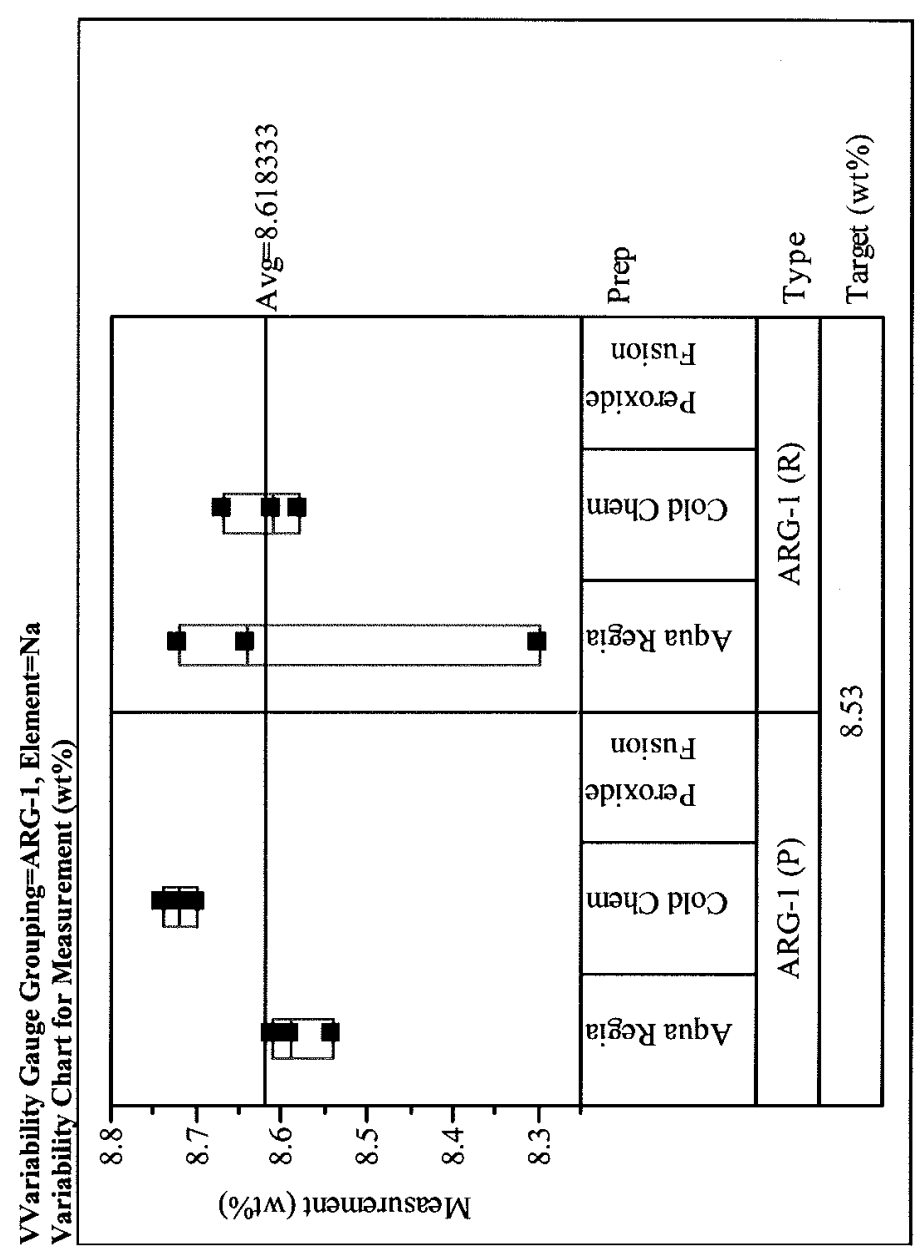

ô.
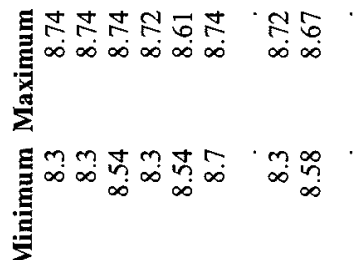

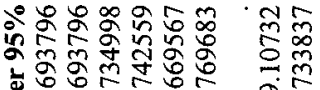

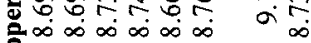
20

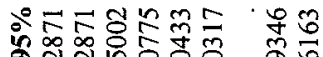

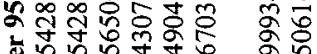

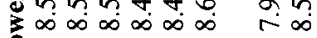
更

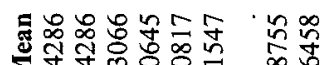

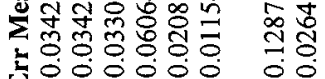
蛋

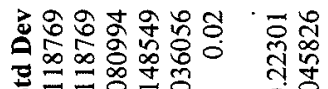
की 태튜

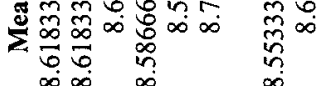

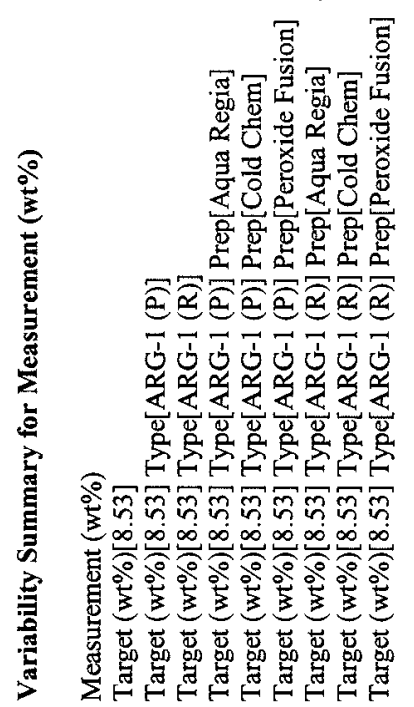




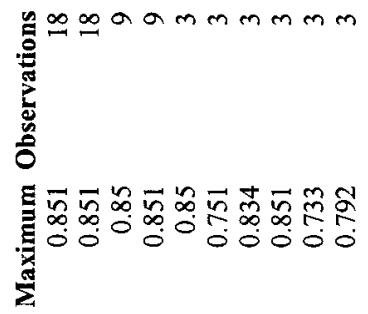

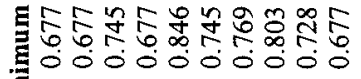
塄

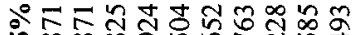

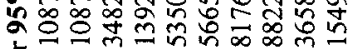

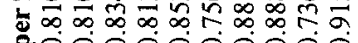
$\stackrel{2}{\circ}$

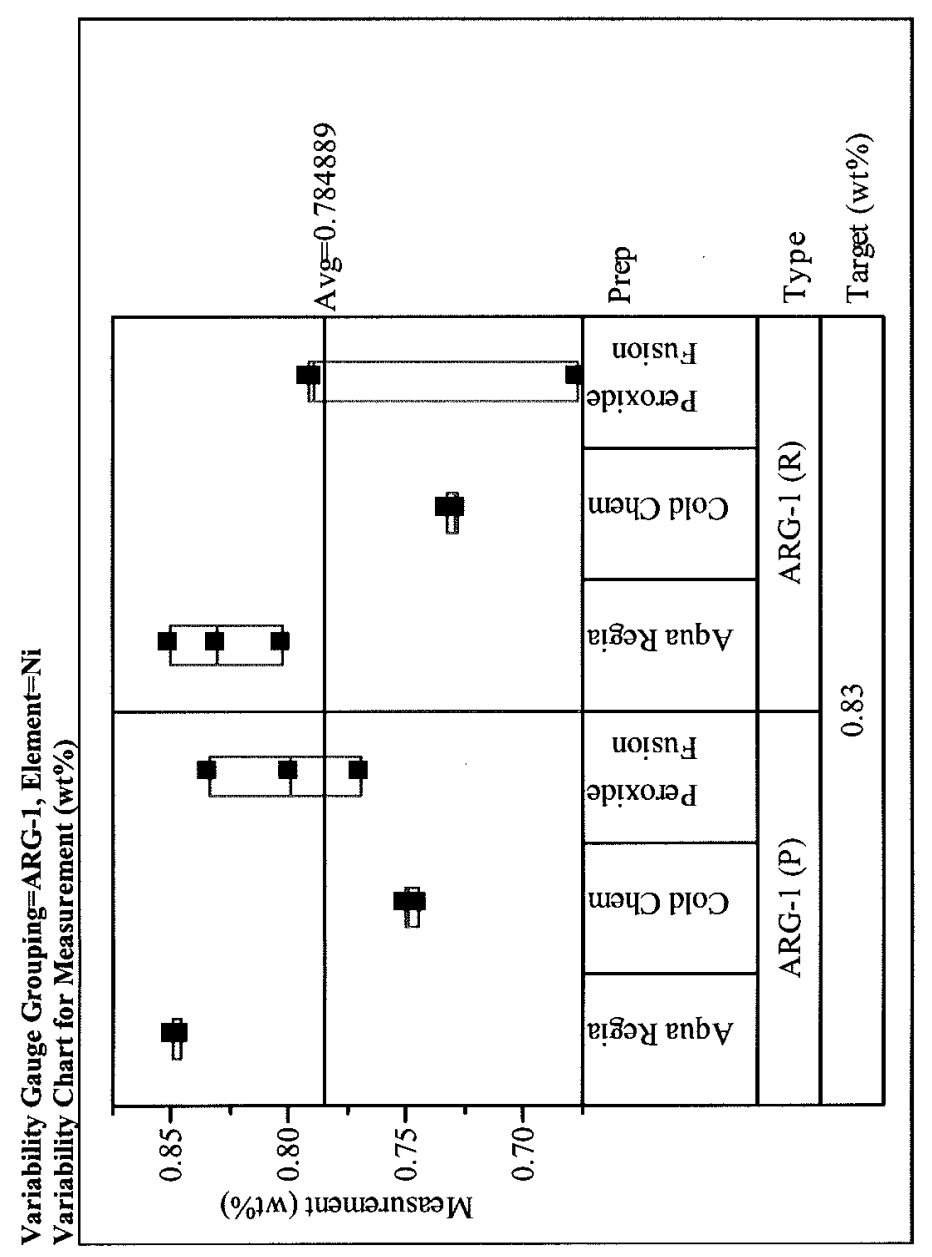

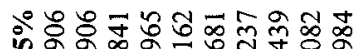

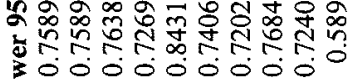
0000000000

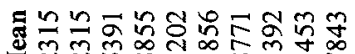
춘 긴 5000000000. 离

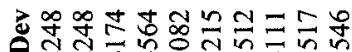

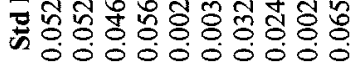
हु के

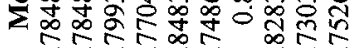
000000 00

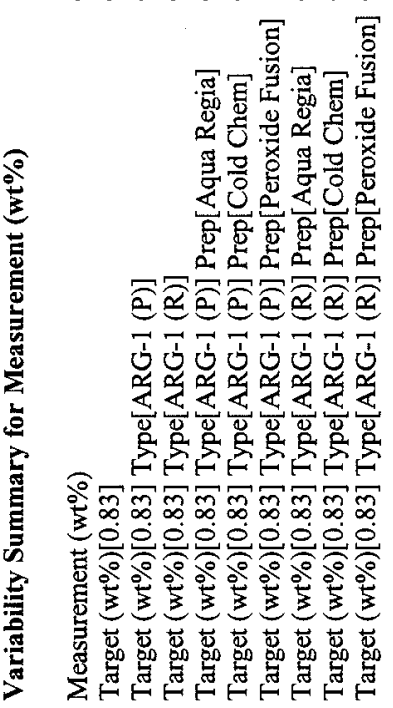


送

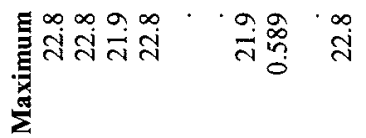

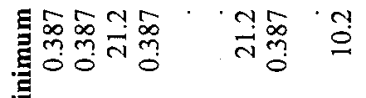
恶

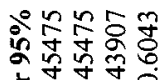
ํํㄹ तें

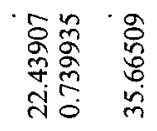

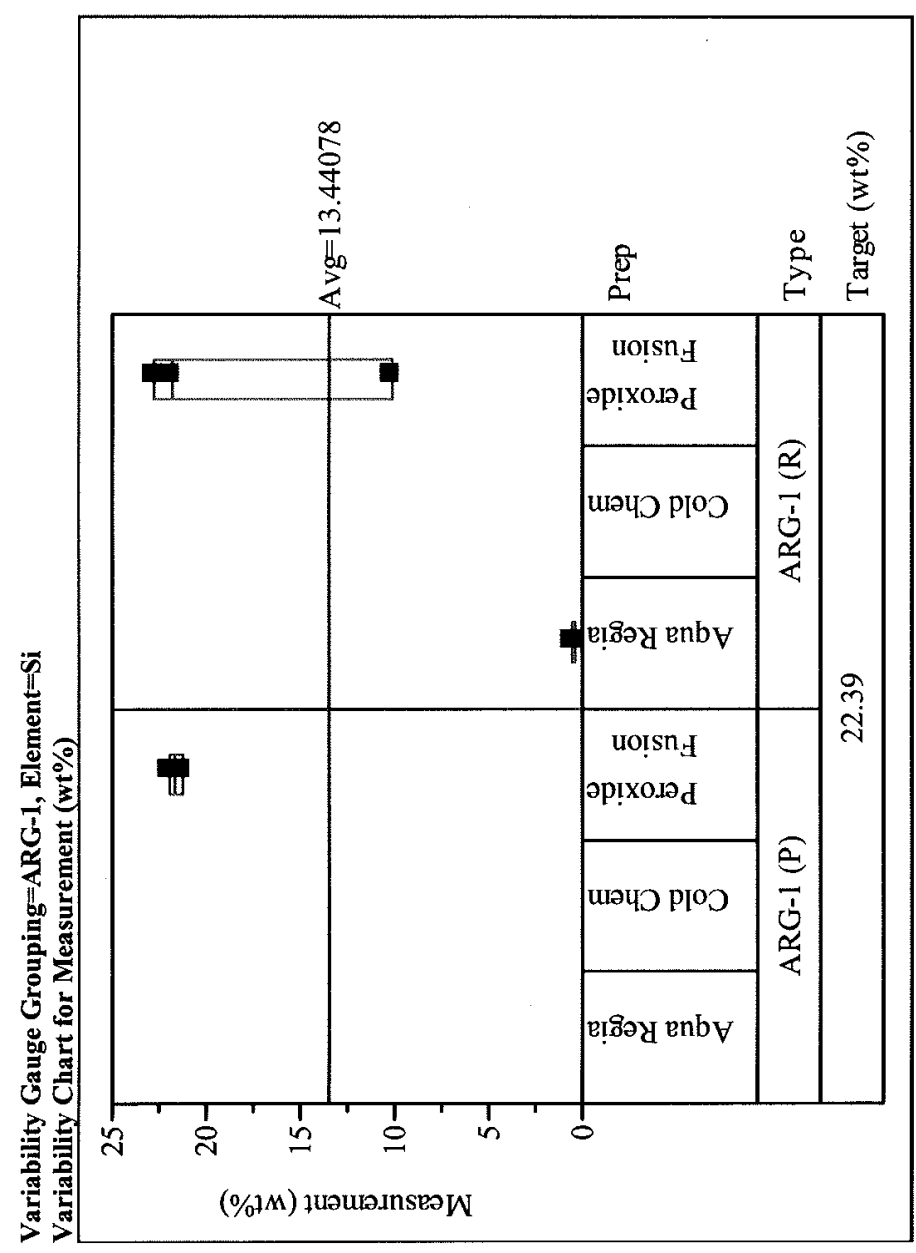

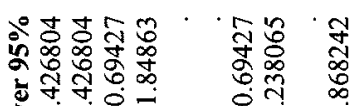

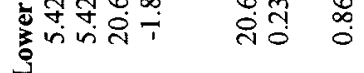

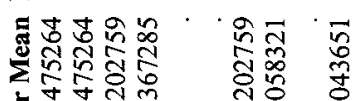

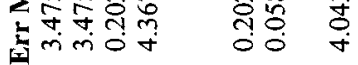
के

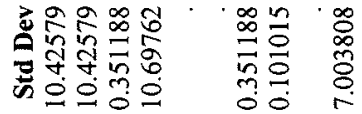

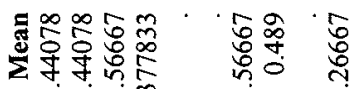
लंख்

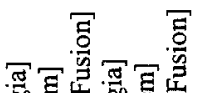

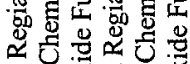

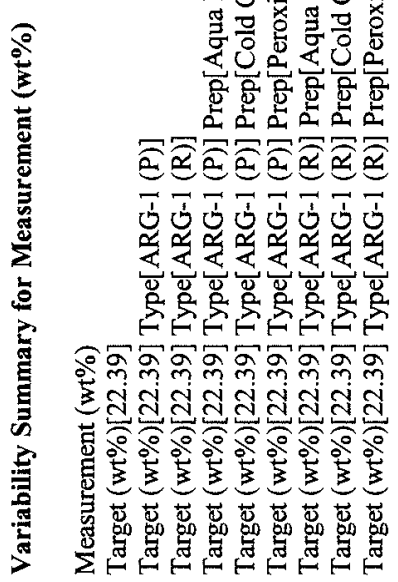




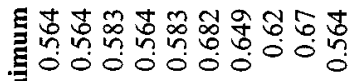
竞

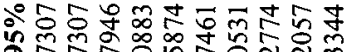

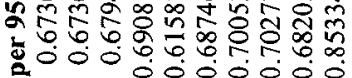
总 000000000

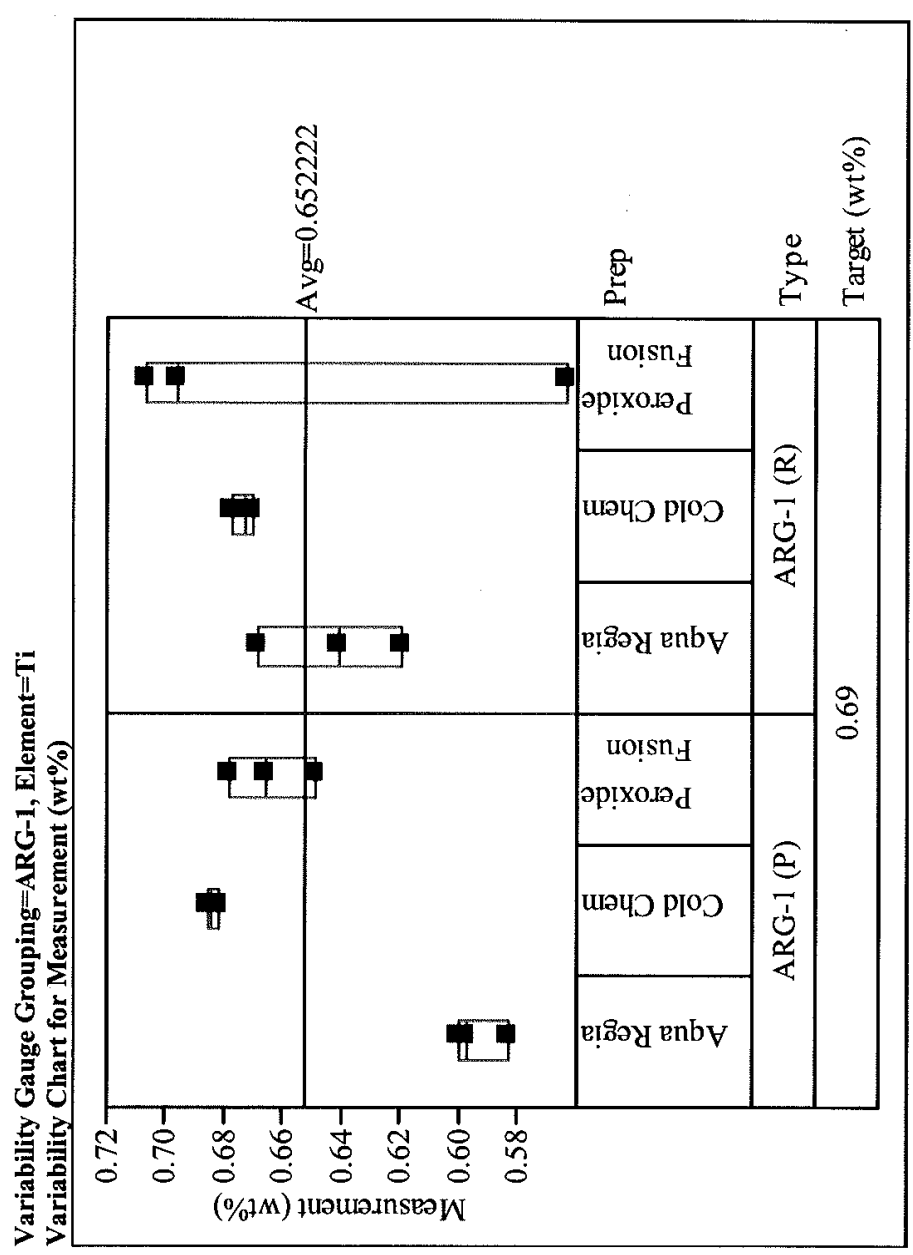

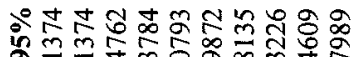
ผ

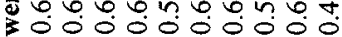
ह0000000000 ฐ =0.0000.00\% is

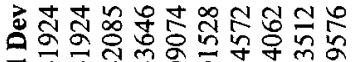
ॠ

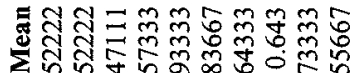

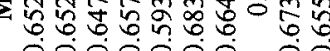

官

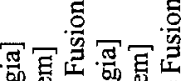

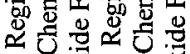

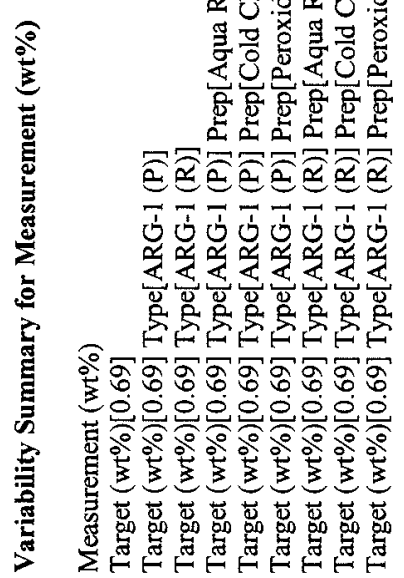



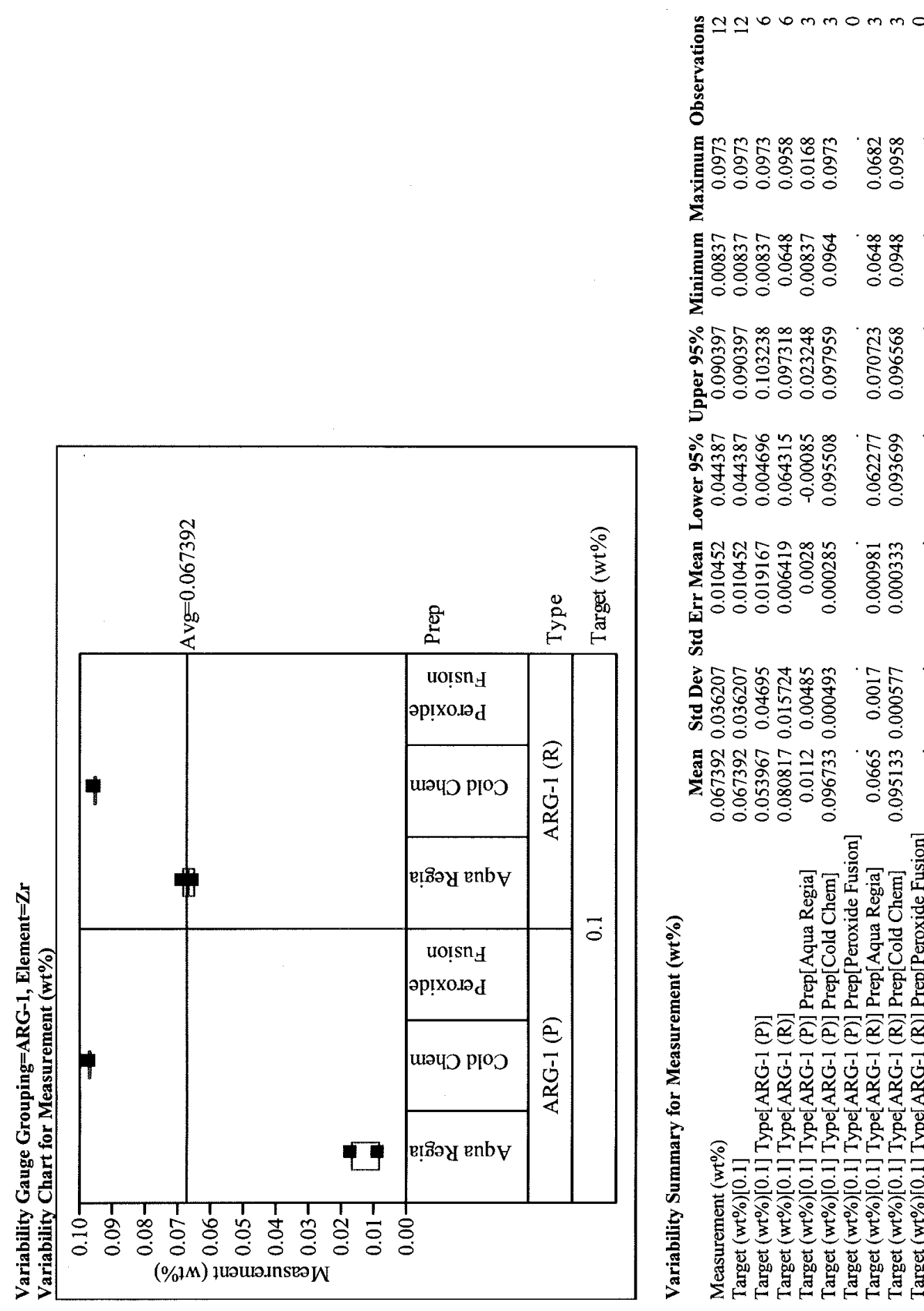

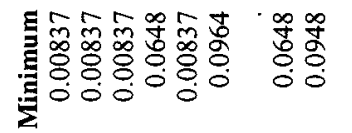

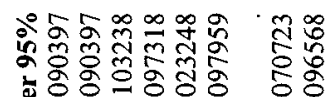

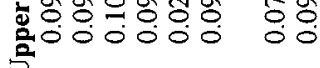

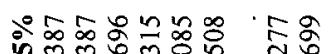

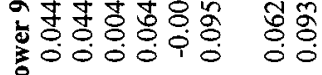

要

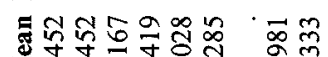

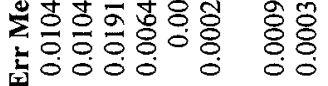

空

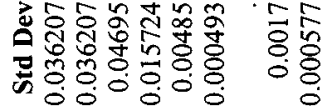

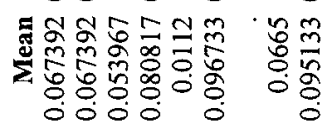

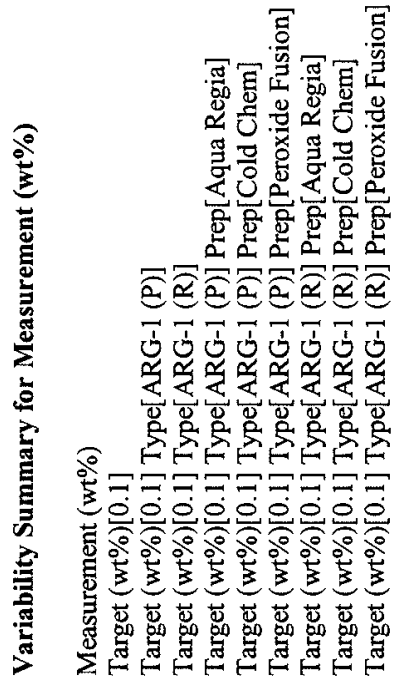


Variability Gauge Grouping $=$ SRAT, Element $=\mathbf{A l}$ Variability Chart for Measurement (wt\%)

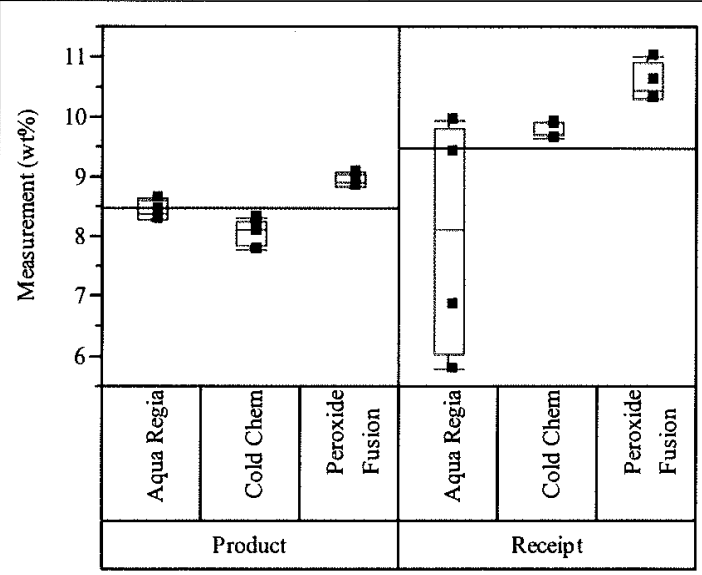

Prep within Type

Variability Summary for Measurement (wt \%)

Measurement (wt\%)

Type[Product]

Type[Receipt

Type[Product] Prep[Aqua Regia]

Type[Product] Prep[Cold Chem]

Type[Product] Prep[Peroxide Fusion]

Type[Receipt] Prep[Aqua Regia]

Type[Receipt] Prep[Cold Chem]

$\begin{array}{rrrr}\text { Mean } & \text { Std Dev } & \text { Std Err Mean } & \text { Lower 95\% } \\ 8.958333 & 1.219325 & 0.248894 & 8.443458 \\ 8.463333 & 0.399871 & 0.115433 & 8.209267 \\ 9.453333 & 1.55376 & 0.448532 & 8.466121 \\ 8.415 & 0.167631 & 0.083815 & 8.148262 \\ 8.0575 & 0.222017 & 0.111009 & 7.704221 \\ 8.9175 & 0.105633 & 0.052817 & 8.749414 \\ 7.9775 & 2.006861 & 1.003431 & 4.784136 \\ 9.8325 & 0.122848 & 0.061424 & 9.637021 \\ 10.55 & 0.331662 & 0.165831 & 10.02225\end{array}$

Upper 95\% Minimum Maximum Observations $9.473209 \quad 5.76$ 8.717399 10.44055 8.681738 8.681738
8.410779 8.410779

11.07775

$\begin{array}{rrr}\text { imum } & \text { Maximum } & \text { Observations } \\ 5.76 & 11 & 24 \\ 7.76 & 9.07 & 12 \\ 5.76 & 11 & 12 \\ 8.26 & 8.64 & 4 \\ 7.76 & 8.29 & 4 \\ 8.83 & 9.07 & 4 \\ 5.76 & 9.92 & 4 \\ 9.65 & 9.91 & 4 \\ 10.3 & 11 & 4\end{array}$

Variability Gauge Grouping=SRAT, Element=B

Variability Chart for Measurement (wt $\%$ )

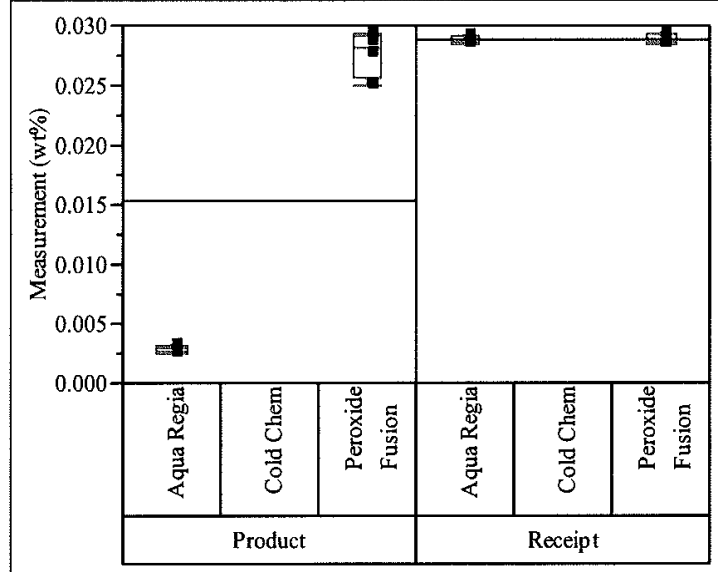

Prep within Type

Variability Summary for Measurement (wt \%)

$\begin{array}{lrrrrrrrr} & \text { Mean } & \text { Std Dev } & \text { Std Err Mean } & \text { Lower 95\% } & \text { Upper 95\% } & \text { Minimum } & \text { Maximum } & \text { Observations } \\ \text { Measurement (wt\%) } & 0.022046 & 0.011473 & 0.002868 & 0.015932 & 0.028159 & 0.00249 & 0.0294 & 16 \\ \text { Type[Product] } & 0.015266 & 0.013299 & 0.004702 & 0.004148 & 0.026385 & 0.00249 & 0.0294 & 8 \\ \text { Type[Receipt] } & 0.028825 & 0.000345 & 0.000122 & 0.028536 & 0.029114 & 0.0285 & 0.0294 & 8 \\ \text { Type[Product] Prep[Aqua Regia] } & 0.002883 & 0.000281 & 0.00014 & 0.002436 & 0.003329 & 0.00249 & 0.00309 & 4 \\ \begin{array}{l}\text { Type[Product] Prep[Cold Chem] } \\ \text { Type[Product] Prep[Peroxide Fusion] }\end{array} & 0.02765 & 0.00191 \dot{4} & 0.000957 & 0.024604 & 0.030696 & 0.025 & 0.0294 & 0 \\ \begin{array}{l}\text { Type[Receipt] Prep[Aqua Regia] } \\ \text { Type[Receipt] Prep[Cold Chem] }\end{array} & 0.0288 & 0.000294 & 0.000147 & 0.028332 & 0.029268 & 0.0285 & 0.0292 & 4 \\ \text { Type[Receipt] Prep[Peroxide Fusion] } & 0.02885 & 0.000436 & 0.000218 & 0.028156 & 0.029544 & 0.0285 & 0.0294 & 4 \\ & & & & & & & & 4\end{array}$


Variability Gauge Grouping $=$ SRAT, Element $=\mathbf{C a}$ Variability Chart for Measurement (wt\%)

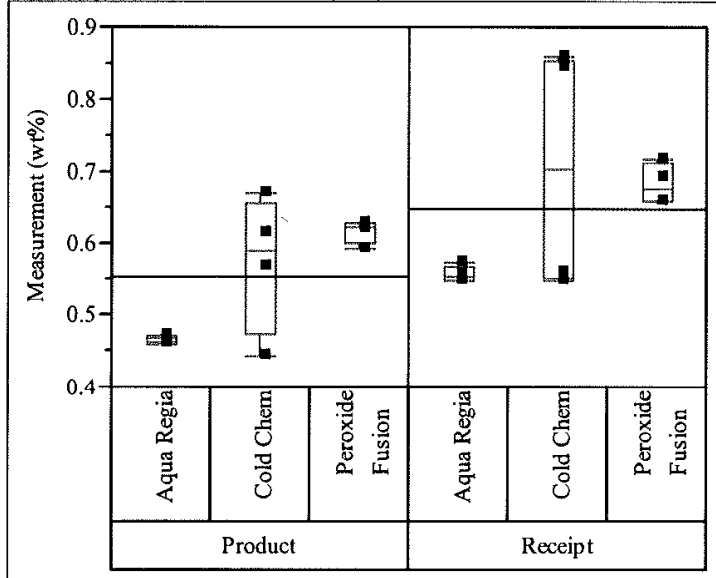

Prep within Type
Variability Summary for Measurement (wt\%)

Measurement (wt\%)

Type[Product]

Type[Receipt]

Type[Product] Prep[Aqua Regia

Type[Product] Prep[Cold Chem]

Type[Product] Prep[Peroxide Fusion]

Type[Receipt] Prep[Aqua Regia]

Type[Receipt] Prep[Cold Chem]

Type[Receipt] Prep[Peroxide Fusion] $\begin{array}{rr}\text { Mean } & \text { Std De } \\ 0.599208 & 0.10908\end{array}$

$0.551583 \quad 0.08406$

0.6468330 .113419

$0.4655 \quad 0.005686$ 0.572750 .097575

0.61650 .016093

0.556250 .01090

$0.70225 \quad 0.1718$

0.6820 .028601

$\begin{array}{rrr}\text { Std Err Mean } & \text { Lower 95\% } & \text { Upper 95\% } \\ 0.022266 & 0.553148 & 0.645269 \\ 0.024266 & 0.498174 & 0.604993 \\ 0.032741 & 0.574771 & 0.718896 \\ 0.002843 & 0.456452 & 0.474548 \\ 0.048788 & 0.417486 & 0.728014 \\ 0.008047 & 0.590892 & 0.642108 \\ 0.005452 & 0.538898 & 0.573602 \\ 0.085945 & 0.428734 & 0.975766 \\ 0.0143 & 0.63649 & 0.72751\end{array}$

\begin{tabular}{rrrr} 
Minimum & Maximum & Observations \\
\hline & 0.441 & 0.857 & 24 \\
3 & 0.441 & 0.67 & 12 \\
6 & 0.548 & 0.857 & 12 \\
8 & 0.457 & 0.469 & 4 \\
4 & 0.441 & 0.67 & 4 \\
8 & 0.593 & 0.629 & 4 \\
2 & 0.548 & 0.572 & 4 \\
1 & 0.548 & 0.857 & 4 \\
1 & 0.659 & 0.718 & 4
\end{tabular}

Variability Gauge Grouping $=\mathrm{SRAT}$, Element $=\mathrm{Cr}$ Variability Chart for Measurement (wt \%)

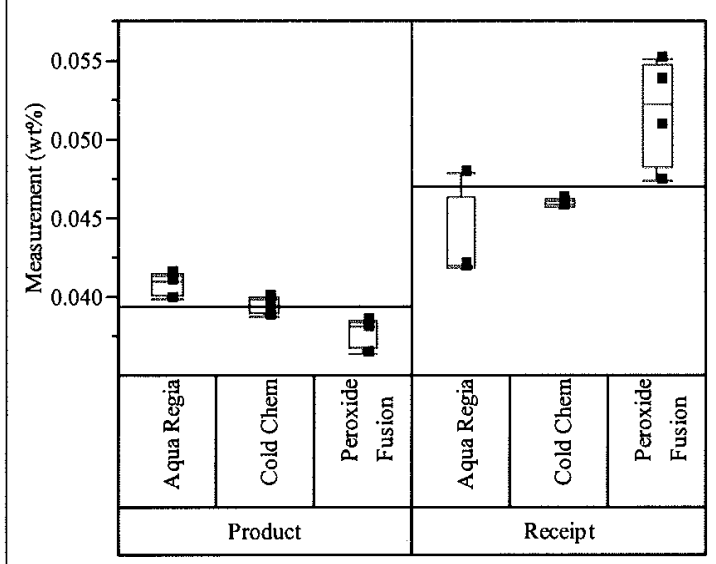

Prep within Type

Variability Summary for Measurement (wt\%)

$\begin{array}{lrrrrrrrr} & \text { Mean } & \text { Std Dev } & \text { Std Err Mean } & \text { Lower 95\% } & \text { Upper 95\% } & \text { Minimum } & \text { Maximum } & \text { Observations } \\ \text { Measurement (wt\%) } & 0.043188 & 0.005053 & 0.001031 & 0.041054 & 0.045321 & 0.0364 & 0.0551 & 24 \\ \text { Type[Product] } & 0.039342 & 0.001467 & 0.000423 & 0.03841 & 0.040274 & 0.0364 & 0.0415 & 12 \\ \text { Type[Receipt] } & 0.047033 & 0.004355 & 0.001257 & 0.044266 & 0.049801 & 0.0419 & 0.0551 & 12 \\ \text { Type[Product] Prep[Aqua Regia] } & 0.04085 & 0.000676 & 0.000338 & 0.039775 & 0.041925 & 0.0399 & 0.0415 & 4 \\ \text { Type[Product] Prep[Cold Chem] } & 0.0394 & 0.00049 & 0.000245 & 0.03862 & 0.04018 & 0.0388 & 0.04 & 4 \\ \text { Type[Product] Prep[Peroxide Fusion] } & 0.037775 & 0.000939 & 0.00047 & 0.03628 & 0.03927 & 0.0364 & 0.0385 & 4 \\ \text { Type[Receipt] Prep[Aqua Regia] } & 0.043425 & 0.002984 & 0.001492 & 0.038677 & 0.048173 & 0.0419 & 0.0479 & 4 \\ \text { Type[Receipt] Prep[Cold Chem] } & 0.0459 & 0.000216 & 0.000108 & 0.045556 & 0.046244 & 0.0457 & 0.0462 & 4 \\ \text { Type[Receipt] Prep[Peroxide Fusion] } & 0.051775 & 0.003399 & 0.0017 & 0.046366 & 0.057184 & 0.0474 & 0.0551 & 4\end{array}$


Variability Gauge Grouping $=$ SRAT, Element $=\mathrm{Cu}$

Variability Chart for Measurement ( $w t \%)$

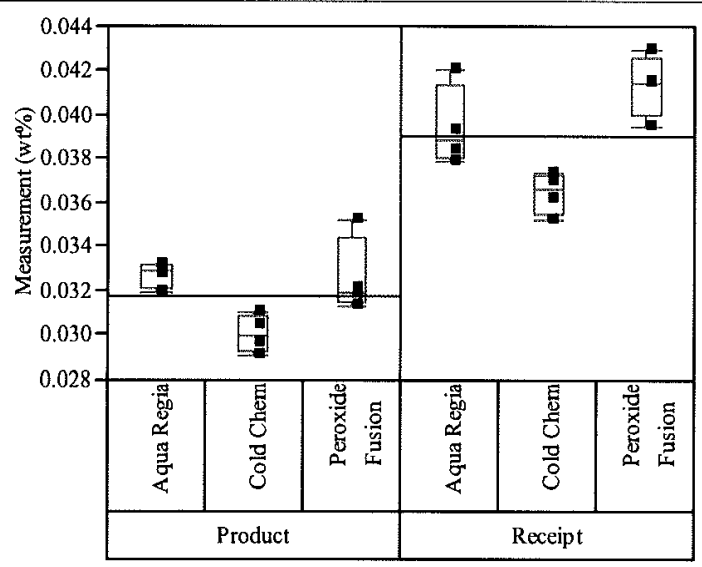

Prep within Type

Variability Summary for Measurement (wt\%)

$\begin{array}{lrrrrrrrr} & \text { Mean } & \text { Std Dev } & \text { Std Err Mean } & \text { Lower 95\% } & \text { Upper 95\% } & \text { Minimum } & \text { Maximum } & \text { Observations } \\ \text { Measurement (wt\%) } & 0.035413 & 0.004251 & 0.000868 & 0.033617 & 0.037208 & 0.0291 & 0.0429 & 24 \\ \text { Type[Product] } & 0.031775 & 0.001674 & 0.000483 & 0.030711 & 0.032839 & 0.0291 & 0.0352 & 12 \\ \text { Type[Receipt] } & 0.03905 & 0.002473 & 0.000714 & 0.037479 & 0.040621 & 0.0352 & 0.0429 & 12 \\ \text { Type[Product] Prep[Aqua Regia] } & 0.0327 & 0.000572 & 0.000286 & 0.031791 & 0.033609 & 0.0319 & 0.0332 & 4 \\ \text { Type[Product] Prep[Cold Chem] } & 0.030025 & 0.000842 & 0.000421 & 0.028685 & 0.031365 & 0.0291 & 0.031 & 4 \\ \text { Type[Product] Prep[Peroxide Fusion] } & 0.0326 & 0.001764 & 0.000882 & 0.029792 & 0.035408 & 0.0313 & 0.0352 & 4 \\ \text { Type[Receipt] Prep[Aqua Regia] } & 0.0394 & 0.001828 & 0.000914 & 0.036492 & 0.042308 & 0.0379 & 0.042 & 4 \\ \text { Type[Receipt] Prep[Cold Chem] } & 0.036425 & 0.000939 & 0.00047 & 0.03493 & 0.03792 & 0.0352 & 0.0373 & 4 \\ \text { Type[Receipt] Prep[Peroxide Fusion] } & 0.041325 & 0.001396 & 0.000698 & 0.039103 & 0.043547 & 0.0395 & 0.0429 & 4\end{array}$

Variability Gauge Grouping=SRAT, Element=Fe

Variability Chart for Measurement (wt \%)

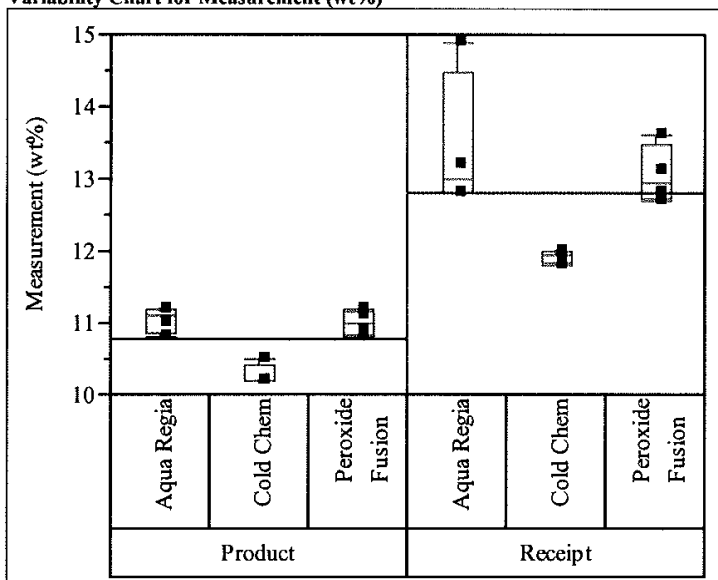

Prep within Type

Variability Summary for Measurement (wt $\%$ )

Measurement ( $w$ t\%)

Type[Product]

Type[Receipt]

Type[Product] Prep[Aqua Regia]

Type[Product] Prep[Cold Chem]

Type[Product] Prep[Peroxide Fusion]

Type[Receipt] Prep[Aqua Regia]

Type[Receipt] Prep[Cold Chem]

Type[Receipt] Prep[Peroxide Fusion]

$\begin{array}{rr}\text { Mean } & \text { Std Dev St } \\ 11.7875 & 1.229815 \\ 10.775 & 0.402549 \\ 12.8 & 0.873863 \\ 11.05 & 0.191485 \\ 10.275 & 0.15 \\ 11 & 0.182574 \\ 13.425 & 1.001249 \\ 11.925 & 0.095743 \\ 13.05 & 0.404145\end{array}$

0.251035
0.116206

$\begin{array}{lll}0.251035 & 11.26819 & 12.30681 \\ 0.116206 & 10.51923 & 11.03077\end{array}$

$\begin{array}{lll}0.116206 & 10.51923 & 11.03077\end{array}$

$\begin{array}{lll}0.252262 & 12.24477 & 13.35523\end{array}$

$0.0745-11.3547$
-0.07568

$\begin{array}{lll}0.075 & 10.03632 & 10.51368\end{array}$

$\begin{array}{lll}0.091287 & 10.70948 & 11.29052\end{array}$

$\begin{array}{lll}0.500625 & 11.83179 & 15.0182\end{array}$

$\begin{array}{lll}0.047871 & 11.77265 & 12.07735\end{array}$

$0.202073 \quad 12.40691 \quad 13.69309$

$\begin{array}{rrr} & & \text { Maximum } \\ 10.2 & 14.9 & 24 \\ 10.2 & 11.2 & 12 \\ 11.8 & 14.9 & 12 \\ 10.8 & 11.2 & 4 \\ 10.2 & 10.5 & 4 \\ 10.8 & 11.2 & 4 \\ 12.8 & 14.9 & 4 \\ 11.8 & 12 & 4 \\ 12.7 & 13.6 & 4\end{array}$


Variability Gauge Grouping=SRAT, Element=K Variability Chart for Measurement (wt \%)

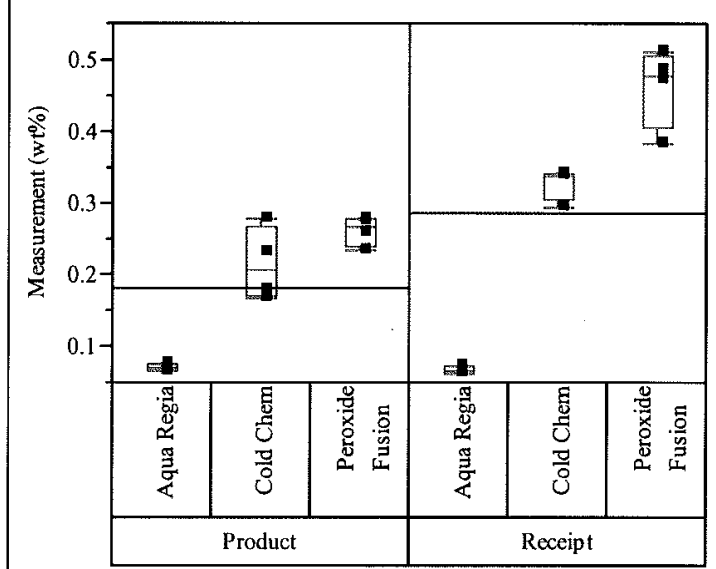

Prep within Type

Variability Summary for Measurement (wt\%)

Measurement (wt\%)

Type[Product]

Type[Receipt]

$\begin{array}{rrr}0.181425 & 0.08942 \\ 0.286408 & 0.174521\end{array}$

Type[Product] Prep[Aqua Regia] $\quad 0.070025 \quad 0.003912$

Type[Product] Prep[Cold Chem] $\quad 0.2135 \quad 0.050633$

Type[Product] Prep[Peroxide Fusion] 0.260750 .02075

Type[Receipt] Prep[Aqua Regia] $\quad 0.0672250 .00358$

Type[Receipt] Prep[Cold Chem] $\quad 0.3290 .022701$

Type[Receipt] Prep[Peroxide Fusion]

$0.463 \quad 0.055642$

Variability Gauge Grouping=SRAT, Element=Li

Variability Chart for Measurement (wt \%)

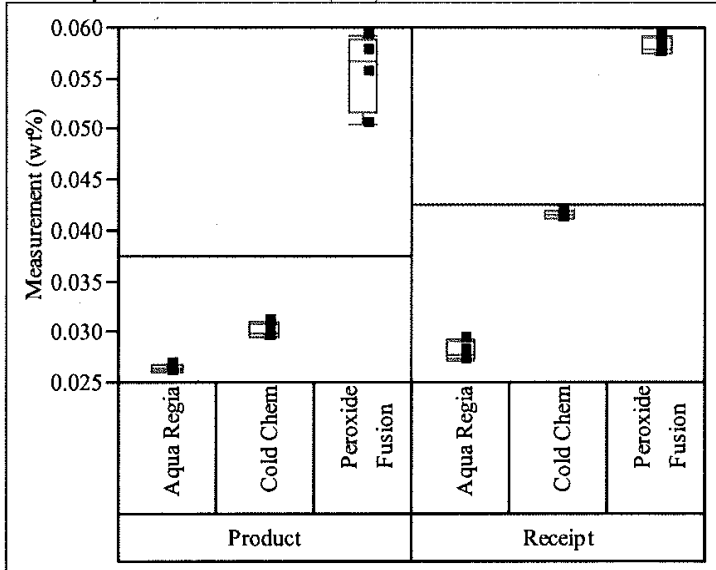

Prep within Type

Variability Summary for Measurement (wt $\%$ )

Measurement ( $w t \%)$

Type[Product]

Type[Receipt]

Type[Product] Prep[Aqua Regia] $\quad 0.0264 \quad 0.000337$

Type[Product] Prep[Cold Chem] $\quad 0.03005 \quad 0.000666$

Type[Product] Prep[Peroxide Fusion] $0.05575 \quad 0.003875$

Type[Receipt] Prep[Aqua Regia] $\quad 0.028 \quad 0.000949$

Type[Receipt] Prep[Cold Chem]

0.0280 .00094

$\begin{array}{llll}\text { Type[Receipt] Prep[Cold Chem] } & 0.041525 & 0.000443 \\ \text { Type[Receipt] Prep[Peroxide Fusion] } & 0.058175 & 0.000862\end{array}$

\begin{tabular}{rrrrrrr} 
& Std Err Mean & Lower 95\% & Upper 95\% & Minimum & Maximum & Observations \\
\hline & 0.002721 & 0.034354 & 0.045612 & 0.026 & 0.0593 & 24 \\
\hline & 0.003983 & 0.028634 & 0.046166 & 0.026 & 0.0593 & 12 \\
& 0.003727 & 0.034365 & 0.050769 & 0.0272 & 0.0593 & 12 \\
& 0.000168 & 0.025864 & 0.026936 & 0.026 & 0.0268 & 4 \\
6 & 0.000333 & 0.028991 & 0.031109 & 0.0295 & 0.031 & 4 \\
& 0.001938 & 0.049584 & 0.061916 & 0.0504 & 0.0593 & 4 \\
& 0.000474 & 0.02649 & 0.02951 & 0.0272 & 0.0293 & 4 \\
3 & 0.000221 & 0.040821 & 0.042229 & 0.0411 & 0.042 & 4 \\
& 0.000431 & 0.056804 & 0.059546 & 0.0575 & 0.0593 & 4
\end{tabular}


Variability Gauge Grouping=SRAT, Element=Mg

Variability Chart for Measurement (wt \%)

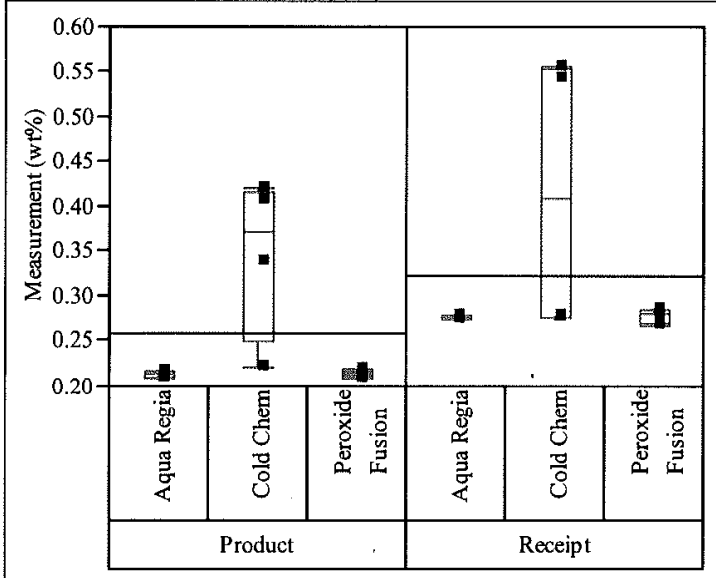

Prep within Type

Variability Summary for Measurement (wt \%)

Measurement (wt \%)

Type[Product]

$\begin{array}{lll}0.257417 & 0.080749\end{array}$

$\begin{array}{lll}0.322083 & 0.106135\end{array}$

$\begin{array}{llll}0.213 & 0.002828\end{array}$

Fusion] $0.21375 \quad 0.002986$

$\begin{array}{lrl}\text { Type[Receipt] Prep[Aqua Regia] } & 0.276 & 0.001633\end{array}$

Type[Receipt] Prep[Cold Chem] $\quad 0.412750 .157432$

Type[Receipt] Prep[Peroxide Fusion] $\quad 0.2775 \quad 0.008583$

$\begin{array}{rr}\text { Etd Err Mean } & \text { Lower 95\% } \\ 0.019997 & 0.248384 \\ 0.02331 & 0.206111 \\ 0.030639 & 0.254648 \\ 0.001414 & 0.208499 \\ 0.045754 & 0.199891 \\ 0.001493 & 0.208998 \\ 0.000816 & 0.273402 \\ 0.078716 & 0.16224 \\ 0.004291 & 0.263843\end{array}$

\begin{tabular}{rrrrr} 
Upper 95\% & Minimum & Maximum & Observations \\
\hline & 0.331116 & 0.209 & 0.556 & 24 \\
1 & 0.308722 & 0.209 & 0.419 & 12 \\
8 & 0.389518 & 0.267 & 0.556 & 12 \\
9 & 0.217501 & 0.209 & 0.215 & 4 \\
1 & 0.491109 & 0.219 & 0.419 & 4 \\
8 & 0.218502 & 0.21 & 0.217 & 4 \\
2 & 0.278598 & 0.274 & 0.278 & 4 \\
4 & 0.66326 & 0.276 & 0.556 & 4 \\
3 & 0.291157 & 0.267 & 0.285 & 4
\end{tabular}

Variability Gauge Grouping $=$ SRAT, Element $=M$

Variability Chart for Measurement (wt \%)

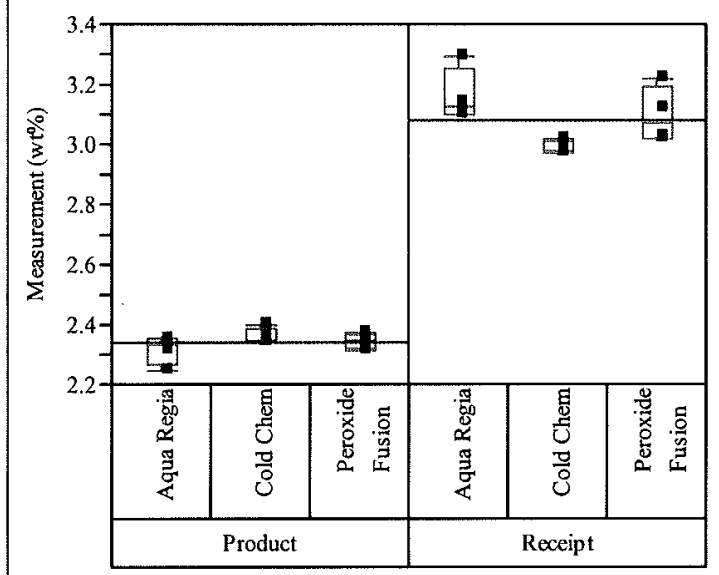

Prep within Type

Variability Summary for Measurement (wt \%)

Measurement (wt\%)

Type[Product]

Type[Receipt]

Type[Product] Prep[Cold Regia]

Type[Product] Prep[Peroxide Fusion]

Type[Produ Prep[Peroxide Fusion

Type[Receipt] Prep[Aqua Regia]

Type[Receipt] Prep[Cold Chem]
Type[Receipt] Prep[Peroxide Fusion]

$\begin{array}{rrrrr}\text { Mean } & \text { Std Dev Std Err Mean } & \text { Lower 95\% } & \text { Upper 95\% } \\ 2.710417 & 0.386461 & 0.078886 & 2.547229 & 2.873605 \\ 2.339167 & 0.03704 & 0.010693 & 2.315633 & 2.362701 \\ 3.081667 & 0.10098 & 0.02915 & 3.017507 & 3.145826 \\ 2.315 & 0.047258 & 0.023629 & 2.239802 & 2.390198 \\ 2.36 & 0.028284 & 0.014142 & 2.314993 & 2.405007 \\ 2.3425 & 0.025 & 0.0125 & 2.302719 & 2.382281 \\ 3.16 & 0.088318 & 0.044159 & 3.019467 & 3.300533 \\ 2.9875 & 0.023629 & 0.011815 & 2.949901 & 3.025099 \\ 3.0975 & 0.093229 & 0.046615 & 2.949152 & 3.245848\end{array}$

$\begin{array}{rrr}\text { Minimum } & \text { Maximum } & \text { Observations } \\ 2.25 & 3.29 & 24 \\ 2.25 & 2.4 & 12 \\ 2.97 & 3.29 & 12 \\ 2.25 & 2.35 & 4 \\ 2.34 & 2.4 & 4 \\ 2.31 & 2.37 & 4 \\ 3.1 & 3.29 & 4 \\ 2.97 & 3.02 & 4 \\ 3.02 & 3.22 & 4\end{array}$


Variability Gauge Grouping=SRAT, Element=Na

Variability Chart for Measurement (wt\%)

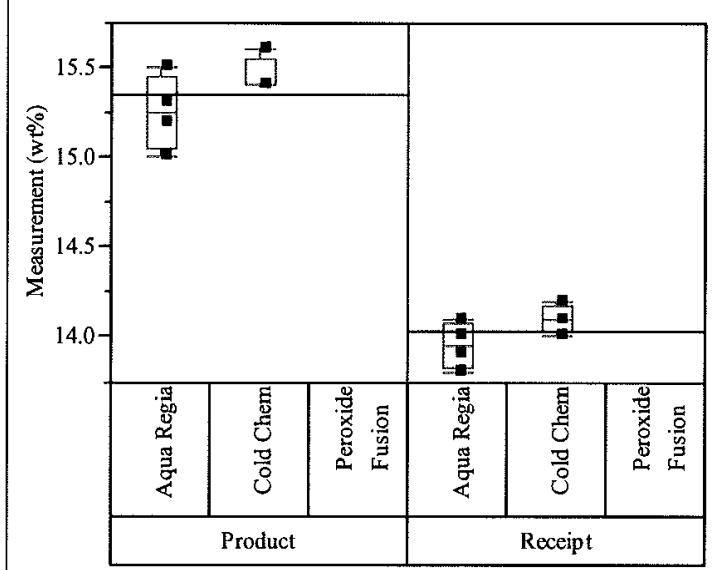

Prep within Type

Variability Summary for Measurement (wt \%)

Measurement (wt\%)

Type[Product]

Type[Receipt]

Type[Product] Prep[Aqua Regia] Type[Product] Prep[Cold Chem]

Type[Product] Prep[Peroxide Fusion]

Type[Receipt] Prep[Aqua Regia]

Type[Receipt] Prep[Cold Chem]

Type[Receipt] Prep[Peroxide Fusion]

Mean Std Dev 14.68750 .701308

$15.35 \quad 0.185164$ $\begin{array}{lll}14.025 & 0.128174\end{array}$

$\begin{array}{lll}15.25 & 0.208167\end{array}$

15.45

0.1

$13.95^{\circ} 0.129099^{\circ}$

14.10 .08165

$$
\begin{array}{rr}
\text { Err Mean } & \text { Lower 95\% } \\
0.175327 & 14.3138 \\
0.065465 & 15.1952 \\
0.045316 & 13.91784 \\
0.104083 & 14.91876 \\
0.05 & 15.29088 \\
\hline . & \\
0.06455 & 13.74457 \\
0.040825 & 13.97008
\end{array}
$$

$\begin{array}{rrrrr}\text { ower 95\% } & \text { Upper 95\% } & \text { Minimum } & \text { Maximum } & \text { Observations } \\ 14.3138 & 15.0612 & 13.8 & 15.6 & 16 \\ 15.1952 & 15.5048 & 15 & 15.6 & 8 \\ 13.91784 & 14.13216 & 13.8 & 14.2 & 8 \\ 14.91876 & 15.58124 & 15 & 15.5 & 4 \\ 15.29088 & 15.60912 & 15.4 & 15.6 & 4 \\ & . & . & & 0 \\ 13.74457 & 14.15543 & 13.8 & 14.1 & 4 \\ 13.97008 & 14.22992 & 14 & 14.2 & 4 \\ . & . & . & . & 0\end{array}$

Variability Gauge Grouping=SRAT, Element $=\mathbf{N}$

Variability Chart for Measurement (wt $\%$ )

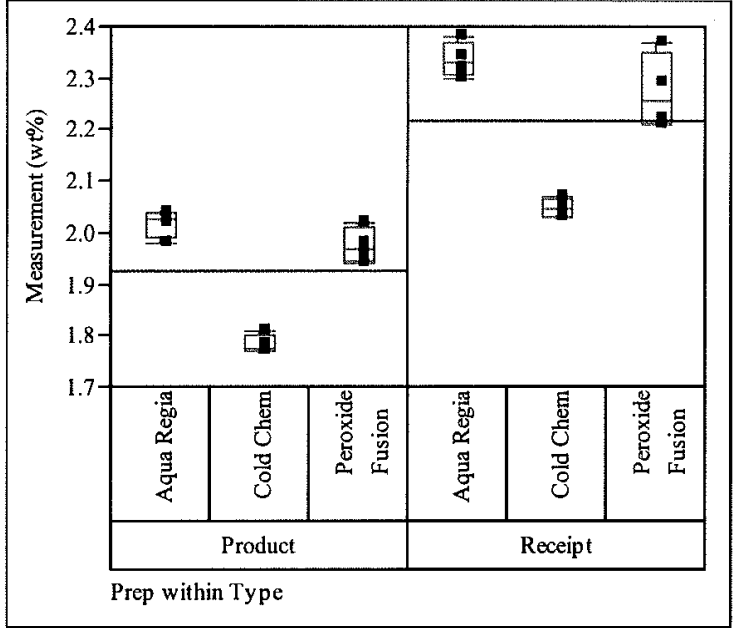

Variability Summary for Measurement (wt \%)

Measurement ( $w \%$

Type[Product]

Type[Product] Prep[Aqua Regia] $\quad \begin{array}{rrr}2.0175 & 0.0263\end{array}$

Type[Product] Prem[Cold Chem] 1.78250 .01893

Type[Product] Prep[Peroxide Fusion] $\quad 1.975 \quad 0.034157$

$2335 \quad 0.034157$

$\begin{array}{llll}\text { Type[Receipt] Prep[Cold Chem] } \quad 2.0475 & 0.017078\end{array}$

Type[Receipt] Prep[Peroxide Fusion] $\quad 2.27250 .074106$

Mean Std De

Err Mean

$0.03929 \quad 1.990389$

$0.031635 \quad 1.855372$

$0.03929 \quad 2.13185$

$0.01315 \quad 1.97565$

$0.009465 \quad 1.752379$

$0.017078 \quad 1.920649$

$\begin{array}{lll}0.008539 & 2.020325 & 2.074675\end{array}$

$\begin{array}{lll}0.037053 & 2.154581 & 2.390419\end{array}$

pper 95\% Minimum Maximum Observations 2.152945

$\begin{array}{rrr}1.77 & \text { Maximum } & \text { Observations } \\ 1.77 & 2.38 & 24 \\ 2.03 & 2.38 & 12 \\ 1.98 & 2.04 & 12 \\ 1.77 & 1.81 & 4 \\ 1.94 & 2.02 & 4 \\ 2.3 & 2.38 & 4 \\ 2.03 & 2.07 & 4 \\ 2.21 & 2.37 & 4\end{array}$


Variability Gauge Grouping $=$ SRAT, Element $=$ Si Variability Chart for Measurement (wt $\%$ )

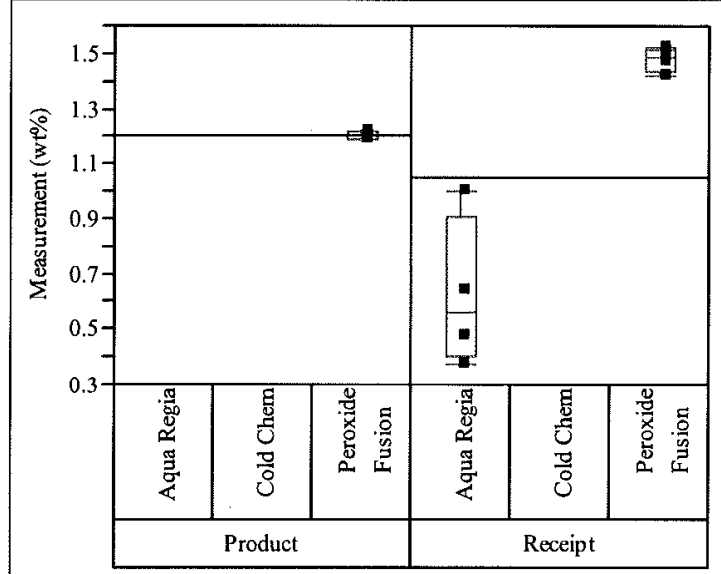

Prep within Type

Variability Summary for Measurement (wt $\%$ )

Measurement (wt\%)

Type[Product]

Type[Receipt]

Type[Product] Prep[Aqua Regia]

Type[Product] Prep[Cold Chem]

Type[Product] Prep[Peroxide Fusion]

Type[Receipt] Prep[Aqua Regia]

Type[Receipt] Prep[Cold Chem] $\begin{array}{rr}\text { Mean Std Dev } \\ 1.10125 & 0.40050\end{array}$

$\begin{array}{lll}1.205 & 0.01732\end{array}$

$1.049375 \quad 0.49265$

\section{$\begin{array}{rr}0.115615 & 0.846784 \\ 0.00866 & 1.17439\end{array}$ \\ 0.174178}

1.177439
0.63751

Upper 95\% Minimum Maximum Observations $\begin{array}{ll}1.355716 & 0.372\end{array}$

1.232561

1.46124

1.19
0.372

$0.00866 \quad 1.177439$

$1.232561 \quad 1.19$

$0.137514 \quad 0.183618$

1.058882

1.19
0.372

$0.021747^{\circ} \quad 1.408292^{\circ}$

1.546708

1.42

\begin{tabular}{rr}
1.52 & 12 \\
1.22 & 4 \\
1.52 & 8 \\
. & 0 \\
1.22 & 0 \\
1 & 4 \\
1 & 4 \\
1.52 & 0 \\
\hline
\end{tabular}

Variability Gauge Grouping=SRAT, Element $=T h$ Variability Chart for Measurement (wt \%)

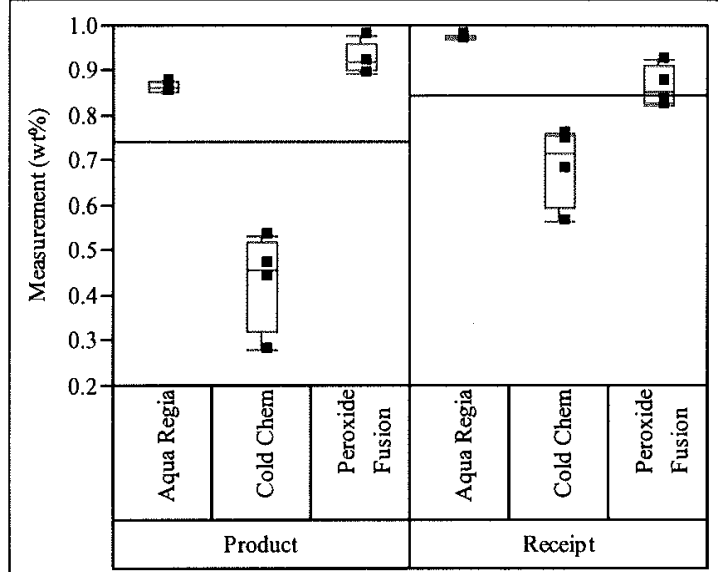

Prep within Type

Variability Summary for Measurement (wt \%)

Measurement (wt\%)

Type[Product]

$\begin{array}{lll}0.039919 & 0.709047 & 0.874203\end{array}$

$\begin{array}{lll}0.068578 & 0.589811 & 0.891689\end{array}$

$\begin{array}{llll}0.23756 & 0.038603 & 0.757535 & 0.927465\end{array}$

$\begin{array}{lll}0.005006 & 0.847818 & 0.879682\end{array}$

Type[Product] Prep[Aqua Regia] $\quad 0.863750 .01001$

Type[Product] Prepl

Type[Product] Prep[Peroxide Fusion]

0.259508

0.603492

0.982274

0.981907
0.830915

0.967093

$0.044672 \quad 0.54658$

0.938595

$\begin{array}{rrr}0.28 & 0.979 & 24 \\ 0.28 & 0.976 & 12 \\ 0.565 & 0.979 & 12 \\ 0.852 & 0.876 & 4 \\ 0.28 & 0.533 & 4 \\ 0.894 & 0.976 & 4 \\ 0.97 & 0.979 & 4 \\ 0.565 & 0.76 & 4 \\ 0.822 & 0.926 & 4\end{array}$


Variability Gauge Grouping $=$ SRAT, Element $=\mathrm{Ti}$ Variability Chart for Measurement (wt \%)

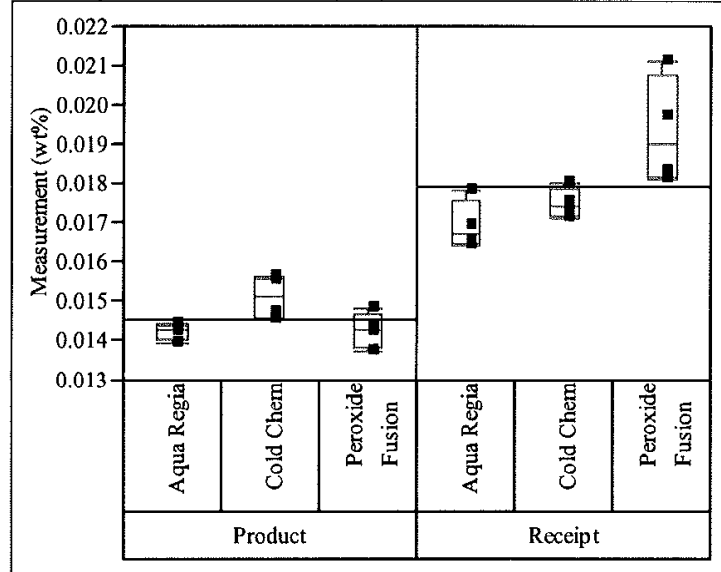

Prep within Type

Variability Summary for Measurement (wt \%)

$\begin{array}{lrrrrrrrr} & \text { Mean } & \text { Std Dev } & \text { Std Err Mean } & \text { Lower 95\% } & \text { Upper 95\% } & \text { Minimum } & \text { Maximum } & \text { Observations } \\ \text { Measurement (wt\%) } & 0.0162 & 0.002004 & 0.000409 & 0.015354 & 0.017046 & 0.0137 & 0.0211 & 24 \\ \text { Type[Product] } & 0.014508 & 0.000573 & 0.000165 & 0.014144 & 0.014872 & 0.0137 & 0.0156 & 12 \\ \text { Type[Receipt] } & 0.017892 & 0.001351 & 0.00039 & 0.017033 & 0.01875 & 0.0164 & 0.0211 & 12 \\ \text { Type[Product] Prep[Aqua Regia] } & 0.0142 & 0.000216 & 0.000108 & 0.013856 & 0.014544 & 0.0139 & 0.0144 & 4 \\ \text { Type[Product] Prep[Cold Chem] } & 0.015075 & 0.000556 & 0.000278 & 0.01419 & 0.01596 & 0.0145 & 0.0156 & 4 \\ \text { Type[Product] Prep[Peroxide Fusion] } & 0.01425 & 0.000451 & 0.000225 & 0.013532 & 0.014968 & 0.0137 & 0.0148 & 4 \\ \text { Type[Receipt] Prep[Aqua Regia] } & 0.0169 & 0.000638 & 0.000319 & 0.015885 & 0.017915 & 0.0164 & 0.0178 & 4 \\ \text { Type[Receipt] Prep[Cold Chem] } & 0.017475 & 0.000386 & 0.000193 & 0.01686 & 0.01809 & 0.0171 & 0.018 & 4 \\ \text { Type[Receipt] Prep[Peroxide Fusion] } & 0.0193 & 0.001395 & 0.000698 & 0.01708 & 0.02152 & 0.0181 & 0.0211 & 4\end{array}$

Variability Gauge Grouping $=$ SRAT, Element $=U$

Variability Chart for Measurement (wt \%)

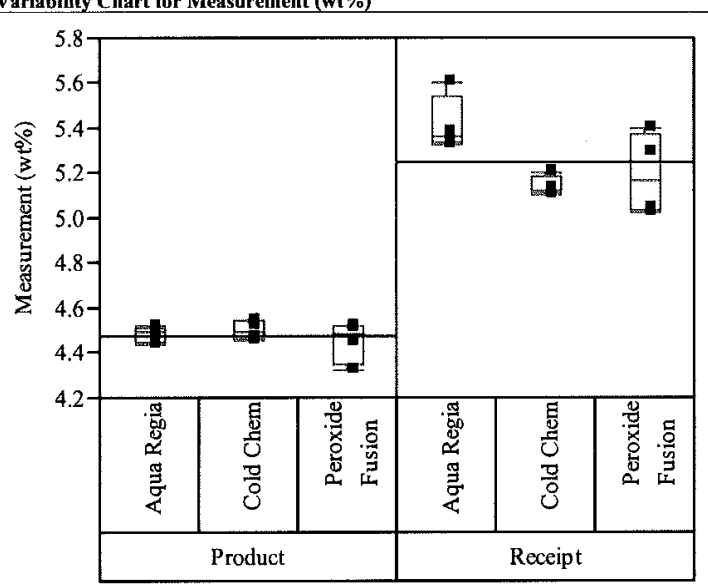

Prep within Type

Variability Summary for Measurement (wt \%)

\begin{tabular}{|c|c|c|c|c|c|c|c|c|}
\hline & Mean & Std Dev & Std Err Mean & Lower $95 \%$ & Upper $95 \%$ & Minimum & Maximum & Observations \\
\hline Measurement ( $\mathrm{wt}^{\mathrm{O}} \%$ ) & 4.86375 & 0.412583 & 0.084218 & 4.689532 & 5.037968 & 4.32 & 5.6 & 24 \\
\hline Type[Product] & 4.479167 & 0.060069 & 0.017341 & 4.441 & 4.517333 & 4.32 & 4.55 & 12 \\
\hline Type[Receipt] & 5.248333 & 0.172091 & 0.049678 & 5.138992 & 5.357674 & 5.03 & 5.6 & 12 \\
\hline Type[Product] Prep[Aqua Regia] & 4.4875 & 0.034034 & 0.017017 & 4.433344 & 4.541656 & 4.44 & 4.52 & 4 \\
\hline Type[Product] Prep[Cold Chem] & 4.5 & 0.042426 & 0.021213 & 4.43249 & 5751 & 4.46 & 4.55 & 4 \\
\hline Type[Product] Prep[Peroxide Fusion] & 4.45 & 0.092014 & 0.046007 & 4.303584 & 4.596416 & 4.32 & 4.52 & 4 \\
\hline Type[Receipt] Prep[Aqua Regia] & 5.415 & 0.125033 & 0.062517 & 5.216044 & 5.613956 & 5.33 & 5.6 & \\
\hline [ype[Receipt] Prep[Cold Chem] & 5.14 & 0.040825 & 0.020412 & 5.075039 & 5.204961 & 5.11 & 5.2 & \\
\hline Type[Receipt] Prep[Peroxide Fusion] & 5.19 & 0.184572 & 0.092286 & 4.896305 & 5.483695 & 5.03 & 5.4 & 4 \\
\hline
\end{tabular}


SRNL-STI-2011-00158, REVISION 0

Variability Gauge Grouping $=$ SRAT, Element $=\mathbf{Z r}$ Variability Chart for Measurement (wt \%)

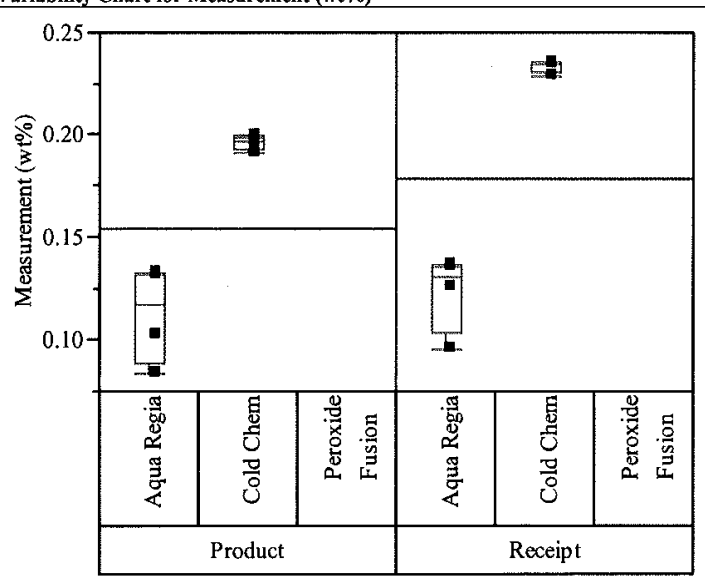

Prep within Type 
Variability Summary for Measurement (wt\%)

Measurement (wt\%)

Type[Product]

Type[Product] Prep[Cold Chem]

Type[Product] Prep[Peroxide Fusion]

Type[Receipt] Prep[Aqua Regia]

Type[Receipt] Prep[Cold Chem]
Type[Receipt] Prep[Peroxide Fusion

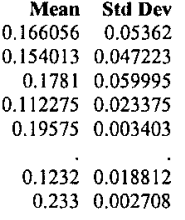

0.12320 .018812 $\begin{array}{lll}0.233 & 0.002708\end{array}$

$\begin{array}{rrrrrr}\text { Std Err Mean } & \text { Lower 95\% } & \text { Upper 95\% } & \text { Minimum } & \text { Maximum } & \text { Observations } \\ 0.013405 & 0.137484 & 0.194628 & 0.0841 & 0.235 & 16 \\ 0.016696 & 0.114533 & 0.193492 & 0.0841 & 0.199 & 8 \\ 0.021211 & 0.127943 & 0.228257 & 0.0958 & 0.235 & 8 \\ 0.011687 & 0.075081 & 0.149469 & 0.0841 & 0.132 & 4 \\ 0.001702 & 0.190334 & 0.201166 & 0.191 & 0.199 & 4 \\ 0.009406 & 0.093266 & 0.153134 & 0.0958 & 0.136 & . \\ 0.001354 & 0.228691 & 0.237309 & 0.229 & 0.235 & 4 \\ . & . & . & . & . & 0\end{array}$

Note that in the table of statistical comparisons for the SRAT Receipt samples (all of the data), the Al comparisons indicate that the AR results are statistically smaller than those from the CC and PF methods. Here are the averages by prep method for all of these data:

\begin{tabular}{|c|c|c|c|c|c|}
\hline Element & $\begin{array}{c}\text { N } \\
\text { Rows }\end{array}$ & $\begin{array}{c}\text { Aqua } \\
\text { Regia }\end{array}$ & $\begin{array}{c}\text { Cold } \\
\text { Chem }\end{array}$ & $\begin{array}{c}\text { Peroxide } \\
\text { Fusion }\end{array}$ & $\begin{array}{c}\text { Statistical } \\
\text { Comparisons }\end{array}$ \\
\hline Al & 4 & 7.9775 & 9.8325 & 10.5500 & AR, CC, PF \\
\hline
\end{tabular}

As seen in the figure below, there are two AR values for the SRAT Receipt samples that are lower than the other results. The summary statistics in the table below the figure indicate a large sample standard deviation for the AR results for $\mathrm{Al}$ for the SRAT Receipt samples.

\section{Variability Chart for Measurement (wt\%)}

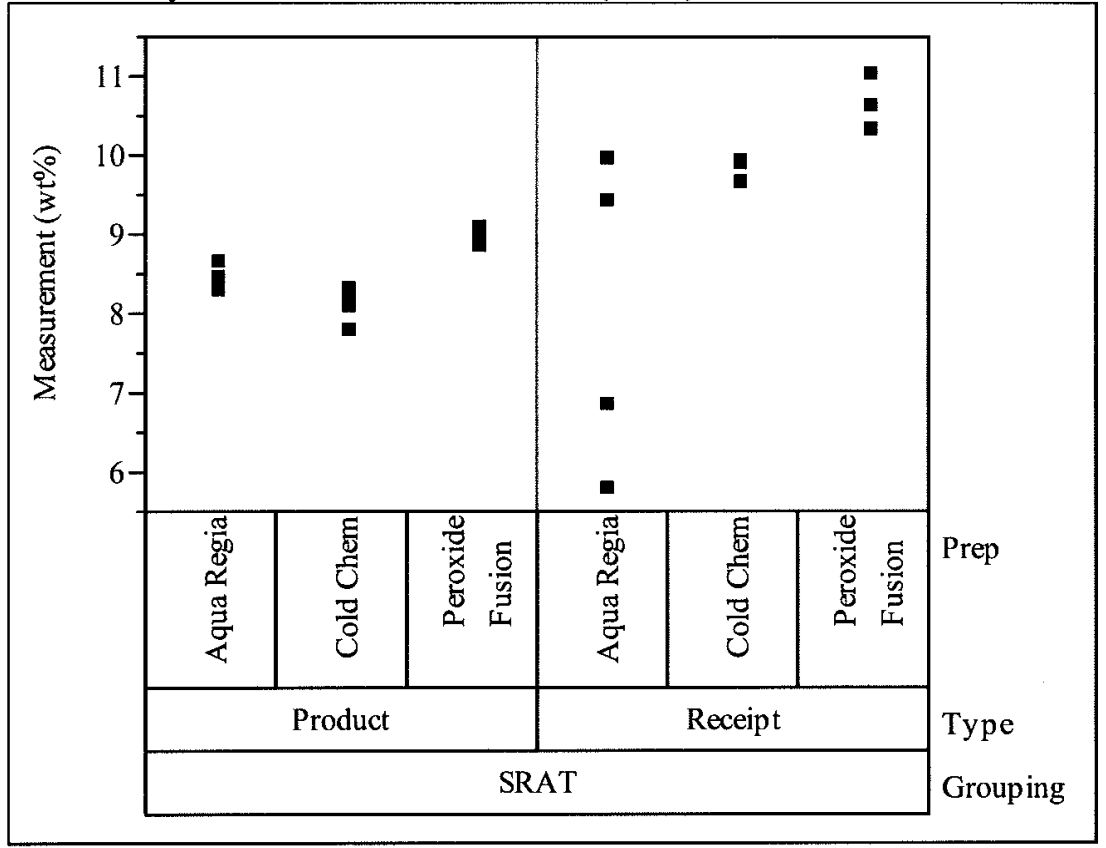

Variability Summary for Measurement (wt\%)

Measurement (wt\%)

Grouping[SRAT]

Grouping[SRAT] Type[Product]

Grouping[SRAT] Type[Receipt]

Grouping[SRAT] Type[Product] Prep[Aqua Regia]

Grouping[SRAT] Type[Product] Prep[Cold Chem]

Grouping[SRAT] Type[Product] Prep[Peroxide

$\begin{array}{rr}\text { Mean } & \text { Std Dev } \\ 8.958333 & 1.219325 \\ 8.958333 & 1.219325 \\ 8.463333 & 0.399871 \\ 9.453333 & 1.55376 \\ 8.415 & 0.167631 \\ 8.0575 & 0.222017 \\ 8.9175 & 0.105633\end{array}$

$\begin{array}{rr}\begin{array}{r}\text { Std Err } \\ \text { Mean }\end{array} & \begin{array}{r}\text { Lower } \\ \mathbf{9 5 \%}\end{array} \\ 0.248894 & 8.443458 \\ 0.248894 & 8.443458 \\ 0.115433 & 8.209267 \\ 0.448532 & 8.466121 \\ 0.083815 & 8.148262 \\ 0.111009 & 7.704221 \\ 0.052817 & 8.749414\end{array}$

8

$\begin{array}{rrrr}\begin{array}{r}\text { Upper } \\ \text { 95\% }\end{array} & \text { Minimum } & \text { Maximum } & \text { Observations } \\ 9.473209 & 5.76 & 11 & 24 \\ 9.473209 & 5.76 & 11 & 24 \\ 8.717399 & 7.76 & 9.07 & 12 \\ 10.44055 & 5.76 & 11 & 12 \\ 8.681738 & 8.26 & 8.64 & 4 \\ 8.410779 & 7.76 & 8.29 & 4 \\ 9.085586 & 8.83 & 9.07 & 4\end{array}$


SRNL-STI-2011-00158, REVISION 0

Fusion]

Grouping[SRAT] Type[Receipt] Prep[Aqua Regia]
Mean Std Dev

7.97752 .006861

9.83250 .122848

10.550 .331662

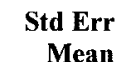

Mean

Grouping[SRAT] Type[Receipt] Prep[Cold Chem]

Grouping[SRAT] Type[Receipt] Prep[Peroxide

Fusion] $\begin{array}{ll}1.003431 & 4.784136 \\ 0.061424 & 9.637021 \\ 0.165831 & 10.02225\end{array}$
Lower

95\%
Upper Minimum Maximum Observations 95\%

11.17086
10.02798

11.07775
5.76
9.65
10.3
9.92
9.91

11

If the two low $\mathrm{Al}$ values are excluded from the analysis (as indicated in the figure below), the summary statistics for the $\mathrm{AR} \mathrm{Al}$ values are more in line with the values provided by the other preparation methods.

\section{Variability Gauge}

Variability Chart for Measurement (wt \%)

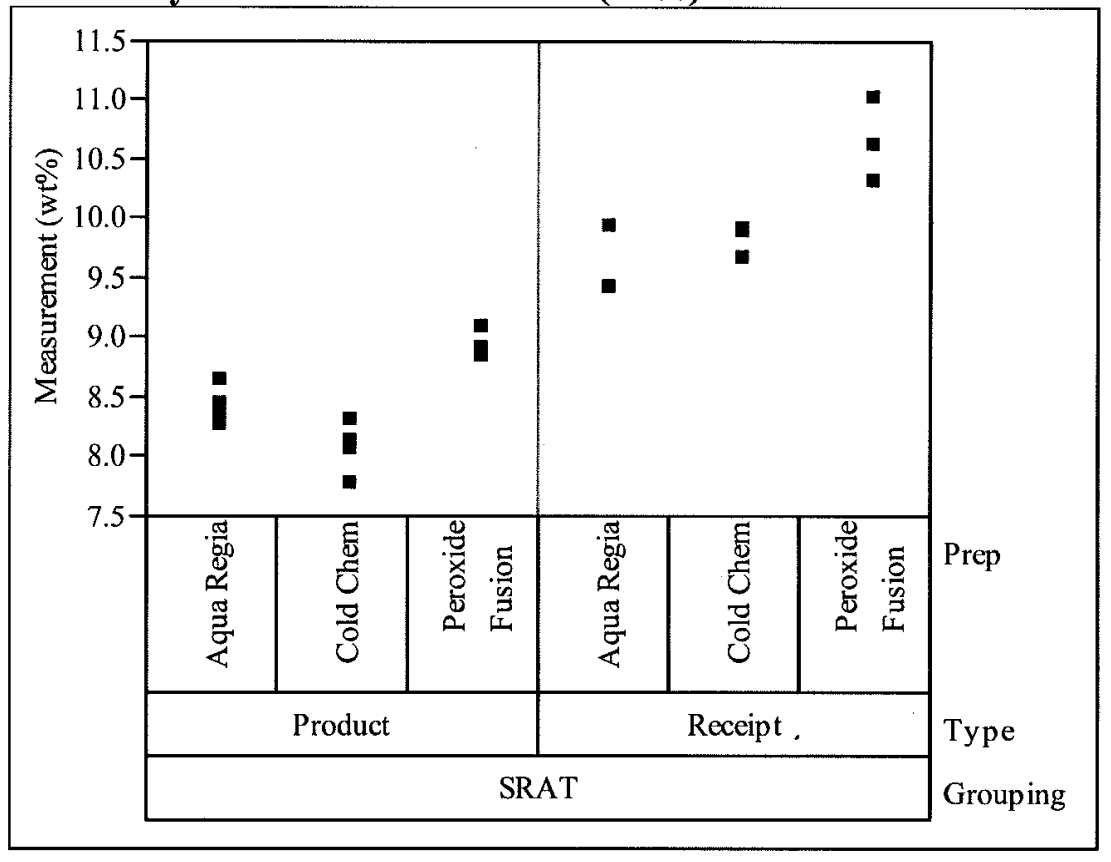

\section{Variability Summary for Measurement (wt\%)}

Measurement (wt\%)

Grouping[SRAT]

Grouping[SRAT] Type[Product]

Grouping[SRAT] Type[Receipt]

Grouping[SRAT] Type[Product] Prep[Aqua Regia] Grouping[SRAT] Type[Product] Prep[Cold Chem]

Grouping[SRAT] Type[Product] Prep[Peroxide

Fusion]

Grouping[SRAT] Type[Receipt] Prep[Aqua Regia] Grouping[SRAT] Type[Receipt] Prep[Cold Chem] Grouping[SRAT] Type[Receipt] Prep[Peroxide Fusion]
Mean Std Dev

9.2009090 .928362

9.2009090 .928362

$\begin{array}{lll}8.463333 & 0.399871\end{array}$

10.0860 .468809

$\begin{array}{lll}8.415 & 0.167631\end{array}$

$\begin{array}{lll}8.0575 & 0.222017\end{array}$

8.91750 .105633

$\begin{array}{lll}9.665 & 0.360624\end{array}$

9.83250 .122848

10.550 .331662

$\begin{array}{rr}\begin{array}{r}\text { Std Err } \\ \text { Mean }\end{array} & \begin{array}{r}\text { Lower } \\ \mathbf{9 5 \%}\end{array} \\ 0.197927 & 8.789296 \\ 0.197927 & 8.789296 \\ 0.115433 & 8.209267 \\ 0.148251 & 9.750634 \\ 0.083815 & 8.148262 \\ 0.111009 & 7.704221 \\ 0.052817 & 8.749414 \\ & \\ 0.255 & 6.424918 \\ 0.061424 & 9.637021 \\ 0.165831 & 10.02225\end{array}$

95\%

Upper Minimum Maximum Observations $95 \%$

9.612522

9.612522

8.717399

10.42137

8.681738

8.410779

9.085586

12.90508

10.02798

11.07775
7.76

7.76

7.76

9.41

8.26

7.76

8.83

9.41

9.65

10.3

11
11
9.07
11
8.64
8.29
9.07
9.92
9.91
11




\section{SRNL-STI-2011-00158, REVISION 0}

In addition, with the two low $\mathrm{Al}$ values excluded from the analysis provided below, the conclusion would be that the PF method yields statistically larger Al concentration measurements when compared against the AR and CC methods.

\section{Oneway Analysis of Measurement (wt\%) By Prep Grouping=SRAT, Type=Receipt, Element=Al}

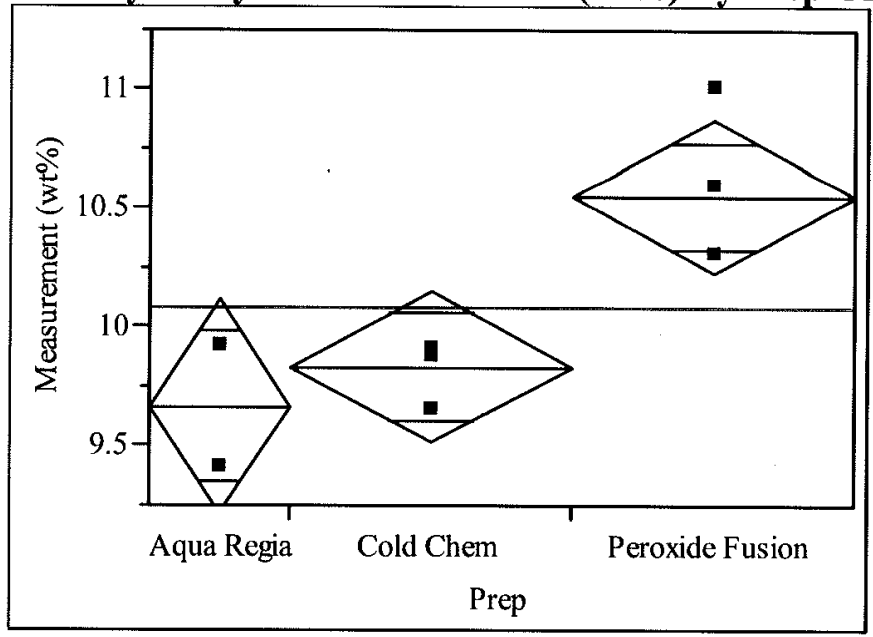

Excluded Rows 2

\section{Oneway Anova}

Summary of Fit

$\begin{array}{lr}\text { Rsquare } & 0.744532 \\ \text { Adj Rsquare } & 0.671542 \\ \text { Root Mean Square Error } & 0.268681 \\ \text { Mean of Response } & 10.086 \\ \text { Observations (or Sum Wgts) } & 10\end{array}$

Analysis of Variance

Source DF Sum of Squares Mean Square F Ratio Prob > F

$\begin{array}{llllll}\text { Prep } & 2 & 1.4727150 & 0.736358 & 10.2004 & 0.0084\end{array}$

$\begin{array}{llll}\text { Error } & 7 & 0.5053250 & 0.072189\end{array}$

C. Total $9 \quad 1.9780400$

Means for Oneway Anova

Level Number Mean Std Error Lower 95\% Upper 95\%

$\begin{array}{llllll}\text { Aqua Regia } & 2 & 9.6650 & 0.18999 & 9.216 & 10.114\end{array}$

$\begin{array}{llllll}\text { Cold Chem } & 4 & 9.8325 & 0.13434 & 9.515 & 10.150\end{array}$

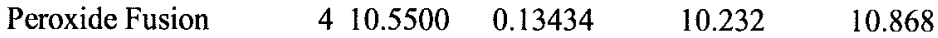

Std Error uses a pooled estimate of error variance

\section{Means Comparisons}

Comparisons for all pairs using Tukey-Kramer HSD

Level

\section{Mean}

Peroxide Fusion A 10.550000

Cold Chem $\quad$ B 9.832500

Aqua Regia $\quad$ B 9.665000

Levels not connected by same letter are significantly different. 
SRNL-STI-2011-00158, REVISION 0

Oneway Analysis of Measurement (wt $\%$ ) By Prep Grouping=SRAT, Type=Product, Element=Al

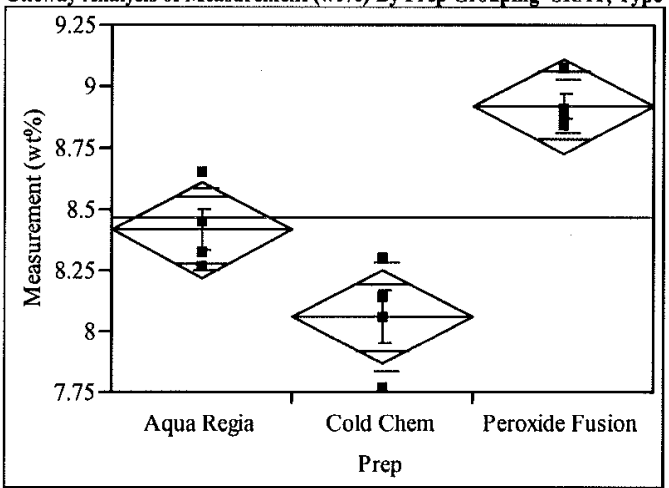

Oneway Anova

Summary of Fit

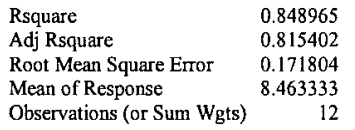

Observations (or Sum Wgts) 12

Analysis of Variance

Source DF Sum of Squares Mean Square F Ratio Prob > F

$\begin{array}{lllllll}\text { Prep } & 2 & 1.4932167 & 0.746608 & 25.2945 & 0.0002\end{array}$

$\begin{array}{llll}\text { Prep } & 2 & 1.4932167 & 0.746608 \\ \text { Eтог } & 9 & 0.2656500 & 0.029517\end{array}$

C. Total $\quad$ I1 1.7588667

$\begin{array}{lrrrrr}\begin{array}{l}\text { Means for Oneway Anova } \\ \text { Level }\end{array} & \text { Number } & \text { Mean } & \text { Std Error } & \text { Lower 95\% } & \text { Upper 95\% } \\ \text { Aqua Regia } & 4 & 8.41500 & 0.08590 & 8.2207 & 8.6093 \\ \text { Cold Chem } & 4 & 8.05750 & 0.08590 & 7.8632 & 8.2518 \\ \text { Peroxide Fusion } & 4 & 8.91750 & 0.08590 & 8.7232 & 9.1118\end{array}$

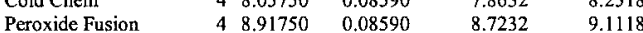

Std Error uses a pooled estimate of error variance

$\begin{array}{lrrrrrr}\text { Means and Std Deviations } & & & & & \\ \text { Level } & \text { Number } & \text { Mean } & \text { Std Dev } & \text { Std Err Mean } & \text { Lower 95\% } & \text { Upper 95\% } \\ \text { Aqua Regia } & 4 & 8.41500 & 0.167631 & 0.08382 & 8.1483 & 8.6817 \\ \text { Cold Chem } & 4 & 8.05750 & 0.222017 & 0.11101 & 7.7042 & 8.4108 \\ \text { Peroxide Fusion } & 4 & 8.91750 & 0.105633 & 0.05282 & 8.7494 & 9.0856\end{array}$

$48.91750 \quad 0.105633$

0.05282

Tests that the Variances are Equal

$\begin{array}{lrrrr}\text { Level } & \text { Count } & \text { Std Dev } & \text { MeanAbsDif to Mean } & \text { MeanAbsDif to Median } \\ \text { Aqua Regia } & 4 & 0.1676305 & 0.1250000 & 0.1250000 \\ \text { Cold Chem } & 4 & 0.2220173 & 0.1525000 & 0.1525000 \\ \text { Peroxide Fusion } & 4 & 0.1056330 & 0.0762500 & 0.0675000\end{array}$

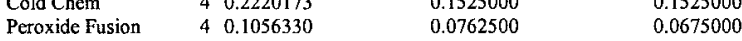

$\begin{array}{lrrrr}\text { Test } & \text { F Ratio } & \text { DFNum } & \text { DFDen } & \text { Prob > F } \\ \text { O'Brien[.5] } & 0.6676 & 2 & 9 & 0.5366 \\ \text { Brown-Forsythe } & 0.6435 & 2 & 9 & 0.5480 \\ \text { Levene } & 0.6180 & 2 & 9 & 0.5604 \\ \text { Bartlett } & 0.6652 & 2 & . & 0.5142\end{array}$

Warning: Small sample sizes. Use Caution.

Welch Anova testing Means Equal, allowing Std Devs Not Equal

F Ratio DFNum DFDen Prob $>$ F

$\begin{array}{rrrr}27.4824 & 2 & 5.4844 & 0.0014\end{array}$

Means Comparisons

Comparisons for all pairs using Tukey-Kramer HSD

$\mathbf{q}^{\star}$ Alpha

$\begin{array}{lrrr}\text { Abs(Dif)-LSD } & \text { Peroxide Fusion } & \text { Aqua Regia } & \text { Cold Chem } \\ \text { Peroxide Fusion } & -0.33918 & 0.16332 & 0.52082 \\ \text { Aqua Regia } & 0.16332 & -0.33918 & 0.01832 \\ \text { Cold Chem } & 0.52082 & 0.01832 & -0.33918\end{array}$

Positive values show pairs of means that are significantly different.

$\begin{array}{lrr}\text { Level } & & \text { Mean } \\ \text { Peroxide Fusion } & \text { A } & 8.9175000 \\ \text { Aqua Regia } & \text { B } & 8.4150000 \\ \text { Cold Chem } & \text { C } 8.0575000\end{array}$

Levels not connected by same letter are significantly different.
Oneway Analysis of Measurement (wt $\%$ ) By Prep Grouping=SRAT, Type=Product, Element=B

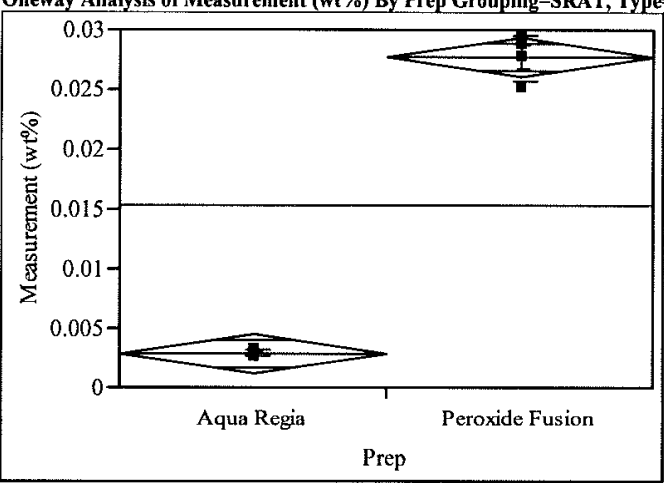

Missing Rows

4

Oneway Anova

Summary of Fit

Rsquare $\quad 0.990933$

Adj Rsquare $\quad 0.989421$

Root Mean Square Error $\quad 0.001368$

Mean of Response $\quad 0.015266$

Observations (or Sum Wgts) 8

Analysis of Variance

Source DF Sum of Squares Mean Square F Ratio Prob $>$ F

$\begin{array}{lllllll}\text { Prep } & 1 & 0.00122686 & 0.001227 & 655.7071 & <.0001\end{array}$

$\begin{array}{llll}\text { Enor } & 6 & 0.00001123 & 1.871 \mathrm{e}-6\end{array}$

Means for Oneway Anova

Level Number Mean Std Error Lower 95\% Upper 95\%

$\begin{array}{lrrrrr}\text { Aqua Regia } & 4 & 0.002883 & 0.00068 & 0.00121 & 0.00456\end{array}$

Cold Chem

Peroxide Fusion

$40.027650 \quad 0.00068 \quad 0.02598 \dot{8} \quad 0.02932$

Std Error uses a pooled estimate of error variance

Means and Std Deviation

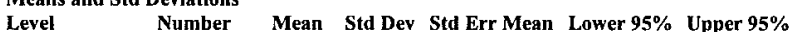

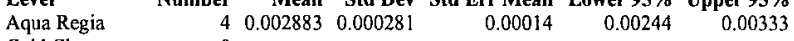

Cold Chem

Peroxide Fusion

$\begin{array}{llll}0 & 0.027650 & 0.001914\end{array}$

$0.00096 \quad 0.02460^{\circ} \quad 0.03070^{\circ}$

Tests that the Variances are Equal

$\begin{array}{lrrrr}\text { Level } & \text { Count } & \text { Std Dev } & \text { MeanAbsDif to Mean } & \text { MeanAbsDif to Median } \\ \text { Aqua Regia } & 4 & 0.0002806 & 0.0002025 & 0.0002025 \\ \text { Cold Chem } & 0 & & 0.0000000 & 0.0000000 \\ \text { Peroxide Fusion } & 4 & 0.0019140 & 0.0013500 & 0.0013500\end{array}$

Test F Ratio DFNum DFDen Prob $>$ F

$\begin{array}{lllll}\text { O'Brien[.5] } & 1.8927 & 1 & 6 & 0.2180 \\ & & 1 & 6 & 0.1138\end{array}$

$\begin{array}{lllll}\text { Brown-Forsythe } & 3.4228 & 1 & 6 & 0.1138 \\ & 4.1888 & 1 & 6 & 0.0866\end{array}$

Levene 4.1888

Warning: Small sample sizes. Use Caution.

Welch Anova testing Means Equal, allowing Std Devs Not Equal

F Ratio DFNum DFDen Prob $>$ F

$\begin{array}{llll}655.7071 & 1 & 3.1289 & <.0001\end{array}$ 
SRNL-STI-2011-00158, REVISION 0 
SRNL-STI-2011-00158, REVISION 0

Oneway Analysis of Measurement (wt $\%$ ) By Prep Grouping=SRAT, Type=Product, Element=Ca

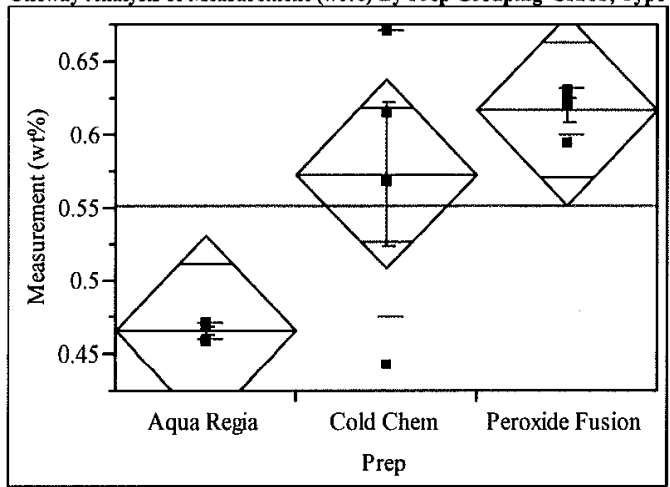

Oneway Anova

Summary of Fit

$\begin{array}{lr}\text { Rsquare } & 0.62128 \\ \text { Adj Rsquare } & 0.53712 \\ \text { Root Mean Square Error } & 0.05719 \\ \text { Mean of Response } & 0.551583 \\ \text { Observations (or Sum Wgts) } & 12 \\ & \\ \text { Analysis of Variance } & \end{array}$

Source DF Sum of Squares Mean Square F Ratio Prob $>$ F

$\begin{array}{llllll}\text { Prep } & 2 & 0.04829017 & 0.024145 & 7.3821 & 0.0127\end{array}$

$\begin{array}{lrrr}\text { Error } & 9 & 0.02943675 & 0.003271\end{array}$

C. Total $11 \quad 0.07772692$

$\begin{array}{lrrrrr}\begin{array}{l}\text { Means for Oneway Anova } \\ \text { Level }\end{array} & \text { Number } & \text { Mean } & \text { Std Error } & \text { Lower 95\% } & \text { Upper 95\% } \\ \text { Aqua Regia } & 4 & 0.465500 & 0.02860 & 0.40081 & 0.53019 \\ \text { Cold Chem } & 4 & 0.572750 & 0.02860 & 0.50806 & 0.63744 \\ \text { Peroxide Fusion } & 4 & 0.616500 & 0.02860 & 0.55181 & 0.68119\end{array}$

Std Error uses a pooled estimate of error variance

Means and Std Deviations

Level Number Mean Std Dev Std Err Mean Lower 95\% Upper 95\%

$\begin{array}{lllllll}\text { Aqua Regia } & 4 & 0.465500 & 0.005686 & 0.00284 & 0.45645 & 0.47455\end{array}$

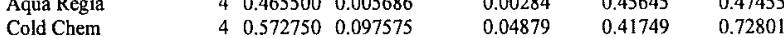

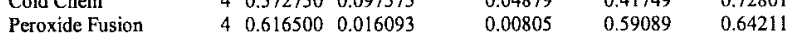

Tests that the Variances are Equal

\begin{tabular}{|c|c|c|c|c|c|}
\hline Level & Count & Std Dev & \multicolumn{2}{|c|}{ MeanAbsDif to Mean } & MeanAbsDif to Median \\
\hline Aqua Regia & 4 & 0.0056862 & & 0.0042500 & 0.0030000 \\
\hline Cold Chem & 4 & 0.0975752 & & 0.0692500 & 0.0692500 \\
\hline Peroxide Fusion & 4 & 0.0160935 & & 0.0117500 & 0.0100000 \\
\hline Test & F Ratio & DFNum & DFDen & Prob $>$ F & \\
\hline O'Brien[.5] & 2.0007 & 2 & 9 & 0.1910 & \\
\hline Brown-Forsythe & 4.2755 & 2 & 9 & 0.0495 & \\
\hline Levene & 4.7274 & 2. & 9 & 0.0395 & \\
\hline Bartlett & 7.9486 & 2 & & 0.0004 & \\
\hline
\end{tabular}

Warning: Small sample sizes. Use Caution.

Welch Anova testing Means Equal, allowing Std Devs Not Equal

$\begin{array}{rrrr}\text { F Ratio } & \text { DFNum } & \text { DFDen } & \text { Prob }>\text { F } \\ 137.6245 & 2 & 4.4498 & <0001\end{array}$

Means Comparisons

Comparisons for all pairs using Tukey-Kramer HSD

$\begin{array}{rr}\mathbf{q}^{\star} & \text { Alpha } \\ 2.79201 & 0.05\end{array}$

Abs(Dif)-LSD Peroxide Fusion Cold Chem Aqua Regia

Peroxide Fusion $\quad-0.11291 \quad-0.06916 \quad 0.03809$

\begin{tabular}{lrrr} 
Cold Chem & -0.06916 & -0.11291 & -0.00566 \\
\hline & 0.03809 & -0.00566 & -0.11291
\end{tabular}

Positive values show pairs of means that are significantly different.

Level Mean

Peroxide Fusion A 0.61650000

$\begin{array}{llll}\text { Cold Chem A } & 0.57275000\end{array}$

Aqua Regia $\quad$ B 0.46550000

Levels not connected by same letter are significantly different.

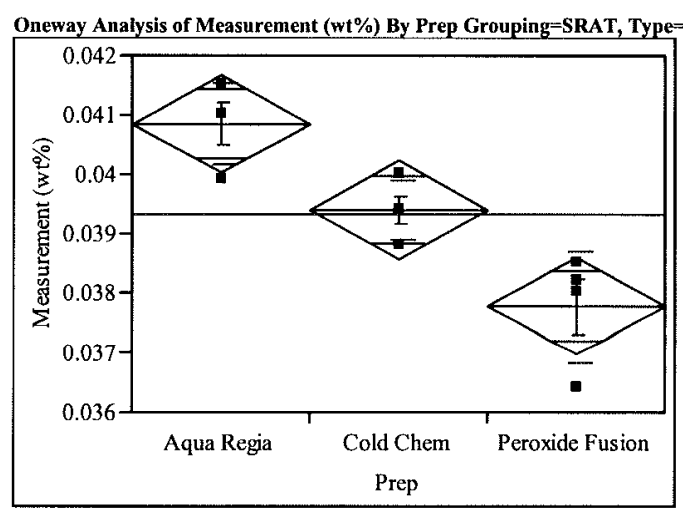

Oneway Anova

Summary of Fit

Rsquare

Adj Rsquare

$\begin{array}{lr}\text { Mean of Response } & 0.039342 \\ \text { Observations (or Sum Wgts) } & 12\end{array}$

Analysis of Variance

Source DF Sum of Squares Mean Square F Ratio Prob > F

$\begin{array}{lrrrrr}\text { Prep } & 2 & 0.00001893 & 9.4658 \mathrm{e}-6 & 17.9826 & 0.0007\end{array}$

$\begin{array}{llll}\text { Prep } & 2 & 0.00001893 & 9.4658 \mathrm{c}-6 \\ \text { Error } & 9 & 0.00000474 & 5.2639 \mathrm{e}-7\end{array}$

C. Total $11 \quad 0.00002367$

Means for Oneway Anov

Level Number Mean Std Error Lower 95\% Upper 95\%

$\begin{array}{llllll}\text { Aqua Regia } & 4 & 0.040850 & 0.00036 & 0.04003 & 0.04167\end{array}$

$\begin{array}{llllll}\text { Cold Chem } & 4 & 0.039400 & 0.00036 & 0.03858 & 0.04022\end{array}$

$\begin{array}{lllll}\text { Peroxide Fusion } \quad 4 & 0.037775 & 0.00036 & 0.03695 & 0.03860\end{array}$

Std Error uses a pooled estimate of error variance

Means and Std Deviations

Level Number Mean Std Dev Std Err Mean Lower 95\% Upper 95\%

$\begin{array}{lllllll}\text { Aqua Regia } & 4 & 0.040850 & 0.000676 & 0.00034 & 0.03977 & 0.04193\end{array}$

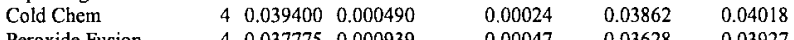

$\begin{array}{lllllll}\text { Peroxide Fusion } & 4 & 0.037775 & 0.000939 & 0.00047 & 0.03628 & 0.03927\end{array}$

Tests that the Variances are Equal

$\begin{array}{lrrrr}\text { Level } & \text { Count } & \text { Std Dev } & \text { MeanAbsDif to Mean } & \text { MeanAbsDif to Median } \\ \text { Aqua Regia } & 4 & 0.0006758 & 0.0004750 & 0.0004000 \\ \text { Cold Chem } & 4 & 0.0004899 & 0.0003000 & 0.0003000 \\ \text { Peroxide Fusion } & 4 & 0.0009394 & 0.0006875 & 0.0005750\end{array}$

$\begin{array}{lrrrr}\text { Test } & \text { F Ratio } & \text { DFNum } & \text { DFDen } & \text { Prob > F } \\ \text { O'Brien[.5] } & 0.4967 & 2 & 9 & 0.6243 \\ \text { Brown-Forsythe } & 0.2383 & 2 & 9 & 0.7928 \\ \text { Levene } & 0.8556 & 2 & 9 & 0.4569 \\ \text { Bartlett } & 0.5367 & 2 & . & 0.5847\end{array}$

Warning: Small sample sizes. Use Caution.

Welch Anova testing Means Equal, allowing Std Devs Not Equal

F Ratio DFNum DFDen Prob $>$ F

$\begin{array}{llll}13.1622 & 2 & 5.6422 & 0.0075\end{array}$

Means Comparisons

Comparisons for all pairs using Tukey-Kramer HSD

$\mathbf{q}^{*}$ Alpha

Abs(Dif)-LSD Aqua Regia Cold Chem Peroxide Fusion

$\begin{array}{lrrr}\text { Aqua Regia } & -0.00143 & 0.00002 & 0.00164\end{array}$

$\begin{array}{lrrr}\text { Cold Chem } & -0.00002 & -0.00143 & 0.00019\end{array}$

$\begin{array}{lll}\text { Peroxide Fusion } \quad 0.00164 & 0.00019 & -0.00143\end{array}$

Positive values show pairs of means that are significantly different.

$\begin{array}{lrrr}\text { Level } & & & \text { Mean } \\ \text { Aqua Regia } & \text { A } & 0.04085000 \\ \text { Cold Chem } & \text { B } & 0.03940000 \\ \text { Peroxide Fusion } & & \text { C } & 0.03777500\end{array}$ 
Levels not connected by same letter are significantly different.

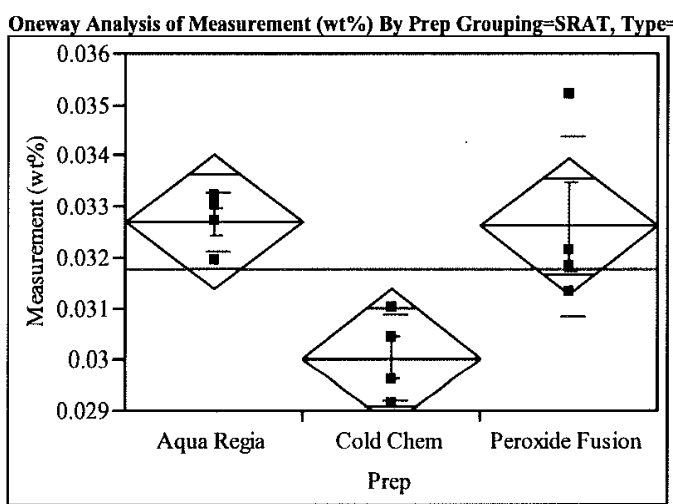

Oneway Anova

Summary of Fit

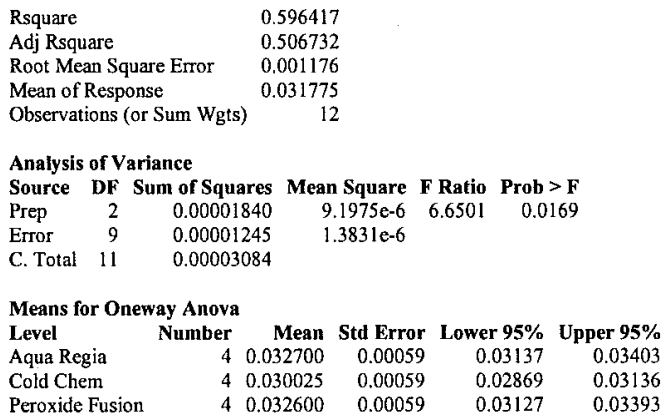

Peroxide Fusion $\quad 40.032600 \quad 0.0005$

Std Enror uses a pooled estimate of error variance

\begin{tabular}{|c|c|c|c|c|c|c|}
\hline \multicolumn{7}{|c|}{ Means and Std Deviations } \\
\hline Level & Number & Mean & Std Dev & Std Err Mean & Lower $95 \%$ & Upper $95 \%$ \\
\hline Aqua Regia & & 0.032700 & 0.000572 & 0.00029 & 0.03179 & 0.03361 \\
\hline Cold Chem & 4 & 0.030025 & 0.000842 & 0.00042 & 0.02868 & 0.03137 \\
\hline Peroxide Fusion & 4 & 0.032600 & 0.001764 & 0.00088 & 0.02979 & 0.03541 \\
\hline
\end{tabular}

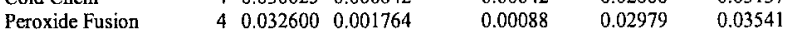

Tests that the Variances are Equal

$\begin{array}{lrrrrr}\text { Level } & \text { Count } & \text { Std Dev } & \text { MeanAbsDif to Mean } & \text { MeanAbsDif to Median } \\ \text { Aqua Regia } & 4 & 0.0005715 & & 0.0004000 & 0.0004000 \\ \text { Cold Chem } & 4 & 0.0008421 & & 0.0006750 & 0.0006750 \\ \text { Peroxide Fusion } & 4 & 0.0017645 & & 0.0013000 & 0.0010500 \\ & & & & & \\ \text { Test } & \text { F Ratio } & \text { DFNum } & \text { DFDen } & \text { Prob > F } & \\ \text { O'Brien[.5] } & 1.0557 & 2 & 9 & 0.3874 & \\ \text { Brown-Forsythe } & 0.5209 & 2 & 9 & 0.6109 & \\ \text { Levene } & 2.3744 & 2 & 9 & 0.1486 & \\ \text { Bartlett } & 1.6980 & 2 & . & 0.1831 & \end{array}$

Warning: Small sample sizes. Use Caution.

Welch Anova testing Means Equal, allowing Std Devs Not Equal

$$
\begin{array}{lrrr}
\text { F Ratio } & \text { DFNum } & \text { DFDen } & \text { Prob }>\text { F } \\
12.5765 & 2 & 5.3367 & 0.0096
\end{array}
$$

\section{Means Comparisons}

Comparisons for all pairs using Tukey-Kramer HSD$$
q^{\star} \text { Alpha }
$$

$2.79201 \quad 0.05$

$\begin{array}{lrrr}\text { Abs(Dif)-LSD } & \text { Aqua Regia } & \text { Peroxide Fusion } & \text { Cold Chem } \\ \text { Aqua Regia } & -0.00232 & -0.00222 & 0.00035 \\ \text { Peroxide Fusion } & -0.00222 & -0.00232 & 0.00025 \\ \text { Cold Chem } & 0.00035 & 0.00025 & -0.00232\end{array}$

Positive values show pairs of means that are significantly different.

$$
\begin{array}{lrr}
\text { Level } & & \text { Mean } \\
\text { Aqua Regia } & \text { A } & 0.03270000 \\
\text { Peroxide Fusion } & \text { A } & 0.03260000 \\
\text { Cold Chem } & \text { B } & 0.03002500
\end{array}
$$

Levels not connected by same letter are significantly different.

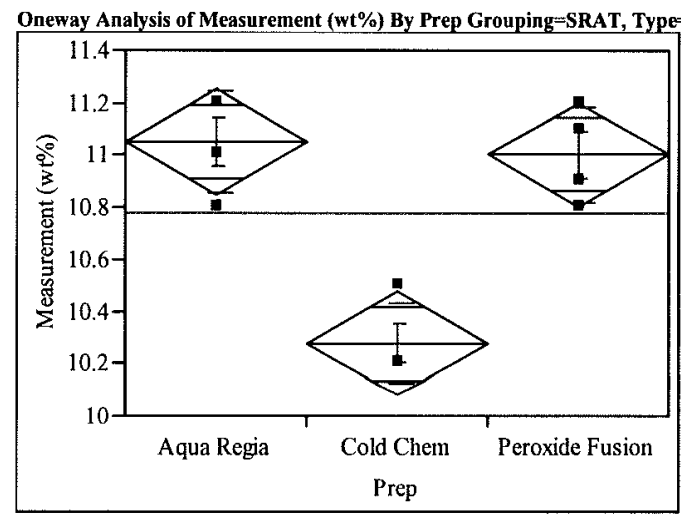

Oneway Anova

Summary of Fit

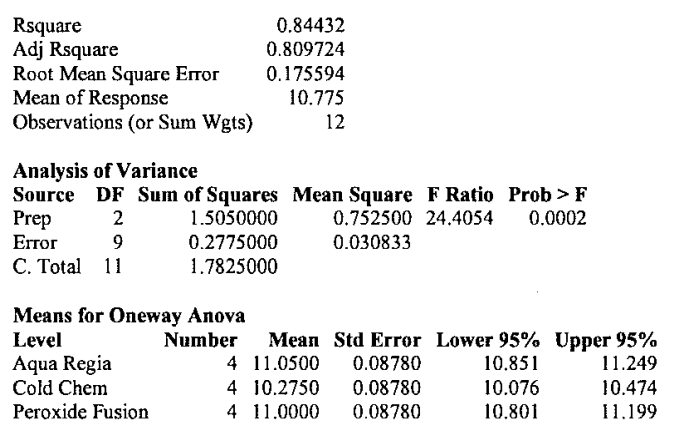

Std Error uses a pooled estimate of error variance

Means and Std Deviations

Level Number Mean Std Dev Std Err Mean Lower 95\% Upper 95\%

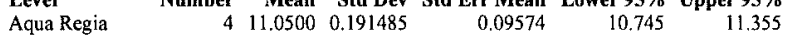

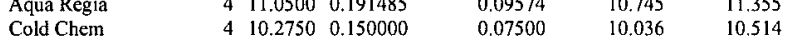

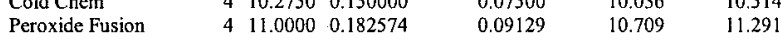

Tests that the Variances are Equal

$\begin{array}{lrrrr}\text { Level } & \text { Count } & \text { Std Dev } & \text { MeanAbsDif to Mean } & \text { MeanAbsDif to Median } \\ \text { Aqua Regia } & 4 & 0.1914854 & 0.1500000 & 0.1500000\end{array}$

$\begin{array}{lllll}\text { Aqua Regia } & 4 & 0.1914854 & 0.1500000 & 0.1500000 \\ \text { Cold Chem } & 4 & 0.1500000 & 0.1125000 & 0.0750000\end{array}$

$\begin{array}{lllll}\text { Cold Chem } & 4 & 0.1500000 & 0.1125000 & 0.0750000 \\ \text { Peroxide Fusion } & 4 & 0.1825742 & 0.1500000 & 0.1500000\end{array}$

Test F Ratio DFNum DFDen Prob $>$ F

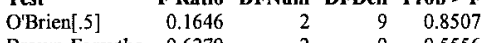

$\begin{array}{lllll}\text { Brown-Forsythe } & 0.6279 & 2 & 9 & 0.5556\end{array}$

$\begin{array}{lllll}\text { Levene } & 0.3600 & 2 & 9 & 0.7073 \\ & 0.0834 & 2 & & 0.9200\end{array}$

Warning: Small sample sizes. Use Caution.

Welch Anova testing Means Equal, allowing Std Devs Not Equal

F Ratio DFNum DFDen Prob $>$ F

$\begin{array}{lrrr}25.2903 & 2 & 5.9268 & 0.0013\end{array}$

Means Comparisons

Comparisons for all pairs using Tukey-Kramer HSD

$\mathbf{q}^{\star}$ Alpha

$2.79201 \quad 0.05$

$\begin{array}{lrrr}\text { Abs(Dif)-LSD } & \text { Aqua Regia } & \text { Peroxide Fusion } & \text { Cold Chem } \\ \text { Aqua Regia } & -0.34667 & -0.29667 & 0.42833\end{array}$

$\begin{array}{llll}\text { Aqua Regia } & -0.34667 & -0.29667 & 0.4283 \\ \text { Peroxide Fusion } & -0.29667 & -0.34667 & 0.3783\end{array}$

$\begin{array}{lrrr}\text { Cold Chem } & 0.42833 & 0.37833 & -0.34667\end{array}$

Positive values show pairs of means that are significantly different.

$\begin{array}{lrr}\text { Level } & & \text { Mean } \\ \text { Aqua Regia } & \text { A } & 11.050000 \\ \text { Peroxide Fusion } & \text { A } & 11.000000 \\ \text { Cold Chem } & \text { B } & 10.275000\end{array}$

Levels not connected by same letter are significantly different. 
SRNL-STI-2011-00158, REVISION 0

Oneway Analysis of Measurement (wt $\%$ ) By Prep Grouping=SRAT, Type=Product, Element=K

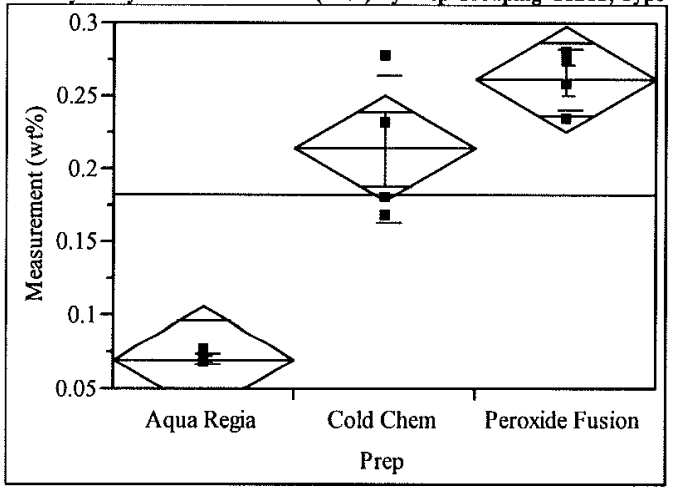

Oneway Anova

Summary of Fit

\begin{tabular}{lrrrrr} 
Rsquare & 0.897337 \\
Adj Rsquare & 0.874523 & \\
Root Mean Square Error & 0.031675 & \\
Mean of Response & 0.181425 & \\
Observations (or Sum Wgts) & 12 & & \\
\multicolumn{5}{l}{} \\
\multicolumn{5}{l}{ Analysis of Variance } \\
Source & DF & Sum of Squares & Mean Square & F Ratio & Prob > F \\
Prep & 2 & 0.07892489 & 0.039462 & 39.3328 & $<.0001$ \\
Error & 9 & 0.00902966 & 0.001003 & & \\
C. Total & 11 & 0.08795454 & & &
\end{tabular}

$\begin{array}{lrrrrr}\begin{array}{l}\text { Means for Oneway Anova } \\ \text { Level }\end{array} & \text { Number } & \text { Mean } & \text { Std Error } & \text { Lower 95\% } & \text { Upper 95\% } \\ \text { Aqua Regia } & 4 & 0.070025 & 0.01584 & 0.03420 & 0.10585 \\ \text { Cold Chem } & 4 & 0.213500 & 0.01584 & 0.17767 & 0.24933 \\ \text { Peroxide Fusion } & 4 & 0.260750 & 0.01584 & 0.22492 & 0.29658\end{array}$

Std Error uses a pooled estimate of error variance

$\begin{array}{lrrrrrr}\text { Means and Std Deviations } & & & & & \\ \text { Level } & \text { Number } & \text { Mean } & \text { Std Dev } & \text { Std Err Mean } & \text { Lower 95\% } & \text { Upper 95\% } \\ \text { Aqua Regia } & 4 & 0.070025 & 0.003912 & 0.00196 & 0.06380 & 0.07625 \\ \text { Cold Chem } & 4 & 0.213500 & 0.050633 & 0.02532 & 0.13293 & 0.29407 \\ \text { Peroxide Fusion } & 4 & 0.260750 & 0.020759 & 0.01038 & 0.22772 & 0.29378\end{array}$

Tests that the Variances are Equal

\begin{tabular}{lrrrrr} 
Level & Count & Std Dev & MeanAbsDif to Mean & MeanAbsDif to Median \\
Aqua Regia & 4 & 0.0039118 & & 0.0032750 & 0.0032750 \\
Cold Chem & 4 & 0.0506327 & & 0.0405000 & 0.0405000 \\
Peroxide Fusion & 4 & 0.0207585 & & 0.0157500 & 0.0157500 \\
& \multicolumn{7}{l}{} \\
Test & F Ratio & DFNum & DFDen & Prob > F & \\
O'Brien[.5] & 3.0380 & 2 & 9 & 0.0981 & \\
Brown-Forsythe & 7.1256 & 2 & 9 & 0.0140 & \\
Levene & 9.0152 & 2 & 9 & 0.0071 & \\
Bartlett & 5.3434 & 2 &. & 0.0048 &
\end{tabular}

Warning: Small sample sizes. Use Caution.

Welch Anova testing Means Equal, allowing Std Devs Not Equal

F Ratio DFNum DFDen Prob > F

$\begin{array}{llll}153.0566 & 2 & 4.1599 & 0.0001\end{array}$

Means Comparisons

Comparisons for all pairs using Tukey-Kramer HSD

$\begin{array}{rr}\mathbf{q}^{\star} & \text { Alpha } \\ 2.79201 & 0.05\end{array}$

Abs(Dif)-LSD Peroxide Fusion Cold Chem Aqua Regia

$\begin{array}{lrrr}\text { Peroxide Fusion } & -0.06253 & -0.01528 & 0.12819\end{array}$

$\begin{array}{lrrr}\text { Cold Chem } & -0.01528 & -0.06253 & 0.08094 \\ \text { Aqua Regia } & 0.12819 & 0.08094 & -0.06253\end{array}$

Positive values show pairs of means that are significantly different.

$\begin{array}{llr}\text { Level } & & \begin{array}{r}\text { Mean } \\ \text { Peroxide Fusion }\end{array} \\ \text { Cold Chem } & \text { A } & 0.26075000 \\ \text { Aqua Regia } & & 0.21350000 \\ & \text { B } & 0.07002500\end{array}$

Levels not connected by same letter are significantly different.

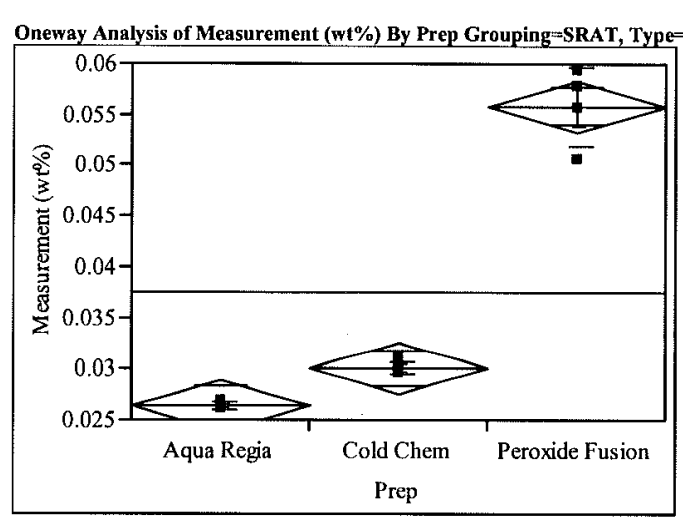

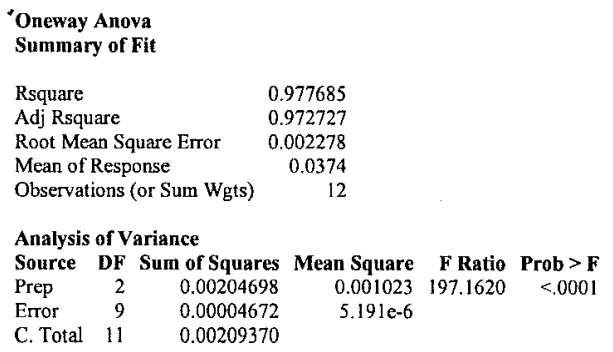

Means for Oneway Anova

Level Number Mean Std Error Lower 95\% Upper 95\%

$\begin{array}{lllllll}\text { Aqua Regia } & 4 & 0.026400 & 0.00114 & 0.02382 & 0.02898\end{array}$

$\begin{array}{llllll}\text { Cold Chem } & 4 & 0.030050 & 0.00114 & 0.02747 & 0.03263\end{array}$

$\begin{array}{llllll}\text { Peroxide Fusion } & 4 & 0.055750 & 0.00114 & 0.05317 & 0.05833\end{array}$

Std Enor uses a pooled estimate of error variance

Means and Std Deviations

Level Number Mean Std Dev Std Err Mean Lower 95\% Upper 95\%

$\begin{array}{lllllll}\text { Aqua Regia } & 4 & 0.026400 & 0.000337 & 0.00017 & 0.02586 & 0.02694\end{array}$

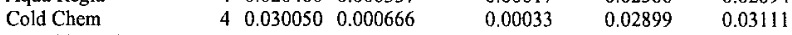

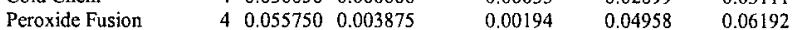

Tests that the Variances are Equal

$\begin{array}{lrrrr}\text { Level } & \text { Count } & \text { Std Dev } & \text { MeanAbsDif to Mean } & \text { MeanAbsDif to Median } \\ \text { Aqua Regia } & 4 & 0.0003367 & 0.0002500 & 0.0002500\end{array}$

\begin{tabular}{|c|c|}
\hline Cold Chem & 40.000665 \\
\hline
\end{tabular}

$\begin{array}{llll}\text { Peroxide Fusion } \quad 4 & 0.0038751 & 0.0027500 & 0.0027500\end{array}$

Test F Ratio DFNum DFDen Prob $>$ F

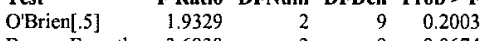

$\begin{array}{lllll}\text { Brown-Forsythe } & 3.6938 & 2 & 9 & 0.0674\end{array}$

$\begin{array}{lllll}\text { Levene } & 4.4953 & 2 & 9 & 0.0443\end{array}$

$\begin{array}{lllll}\text { Bartlett } & 6.8230 & 2 & 0.0011\end{array}$

Warning: Small sample sizes. Use Caution.

Welch Anova testing Means Equal, allowing Std Devs Not Equal

F Ratio DFNum DFDen Prob $>$ F

$\begin{array}{rrrr}137.1468 & 2 & 4.797 & <.0001\end{array}$

Means Comparisons

Comparisons for all pairs using Tukey-Kramer HSD

$\mathbf{q}^{\star}$ Alpha

Abs(Dif)-LSD Peroxide Fusion Cold Chem Aqua Regia

$\begin{array}{lrrr}\text { Peroxide Fusion } & -0.00450 & 0.02120 & 0.02485\end{array}$

\begin{tabular}{lrrr} 
Cold Chem & -0.00450 & 0.02120 & 0.02485 \\
\hline & 0.02120 & -0.00450 & -0.00085
\end{tabular}

$\begin{array}{llll}\text { Aqua Regia } & 0.02485 & -0.00085 & -0.00450\end{array}$

Positive values show pairs of means that are significantly different.

$\begin{array}{lr}\text { Level } & \text { Mean } \\ \text { Peroxide Fusion A } & 0.05575000\end{array}$

$\begin{array}{lll}\text { Peroxide Fusion } & \text { A } & 0.05575000 \\ \text { Cold Chem } & \text { B } & 0.03005000\end{array}$

$\begin{array}{ll}\text { Aqua Regia } & \text { B } 0.02640000\end{array}$ 
SRNL-STI-2011-00158, REVISION 0

Levels not connected by same letter are significantly different.

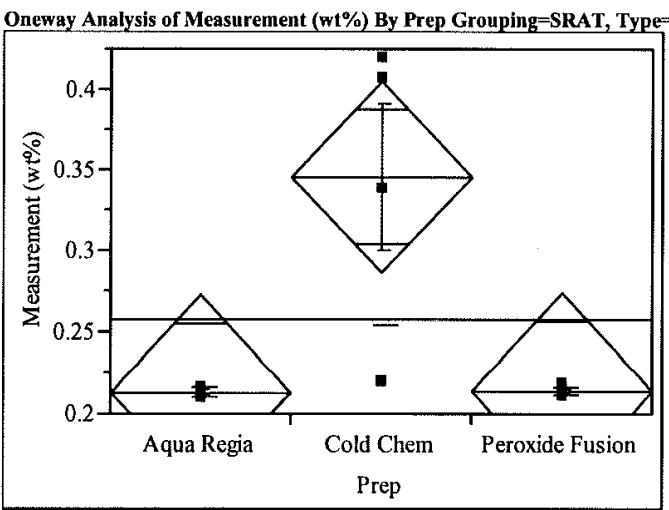

\section{Oneway Anova}

Summary of Fit

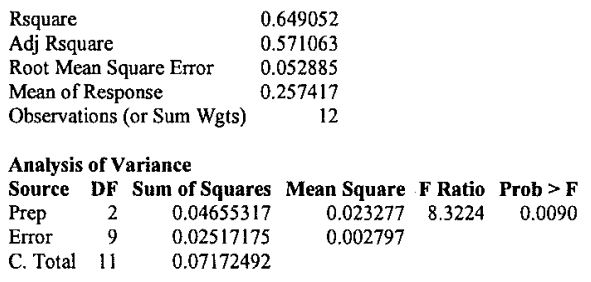

C. Total $11 \quad 0.07172492$

\begin{tabular}{|c|c|c|c|c|c|}
\hline \multicolumn{6}{|c|}{ Means for Oneway Anova } \\
\hline Level & Number & Mean & Std Error & Lower $95 \%$ & Upper $95 \%$ \\
\hline Aqua Regia & 4 & 0.213000 & 0.02644 & 0.15318 & 0.27282 \\
\hline Cold Chem & 4 & 0.345500 & 0.02644 & 0.28568 & 0.40532 \\
\hline Pero & & 0.213750 & 0.0264 & 0.15393 & 0.27357 \\
\hline
\end{tabular}

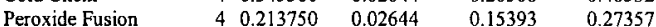

Std Error uses a pooled estimate of error variance

\begin{tabular}{lrrrrrr} 
Means and Std Deviations & & & & & \\
Level & Number & Mean & Std Dev & Std Err Mean & Lower 95\% & Upper 95\% \\
Aqua Regia & 4 & 0.213000 & 0.002828 & 0.00141 & 0.20850 & 0.21750 \\
Cold Chem & 4 & 0.345500 & 0.091508 & 0.04575 & 0.19989 & 0.49111 \\
\hline
\end{tabular}

Peroxide Fusion $\quad 40.2137500 .002986 \quad 0.00149 \quad 0.20900 \quad 0.21850$

Tests that the Variances are Equal

$\begin{array}{lrrrrr}\text { Level } & \text { Count } & \text { Std Dev } & \text { MeanAbsDif to Mean } & \text { MeanAbsDif to Median } \\ \text { Aqua Regia } & 4 & 0.0028284 & & 0.0020000 & 0.0020000 \\ \text { Cold Chem } & 4 & 0.0915077 & & 0.0670000 & 0.0670000 \\ \text { Peroxide Fusion } & 4 & 0.0029861 & & 0.0022500 & 0.0022500 \\ & & & & & \\ \text { Test } & \text { F Ratio } & \text { DFNum } & \text { DFDen } & \text { Prob }>\text { F } & \\ \text { O'Brien[.5] } & 2.1456 & 2 & 9 & 0.1730 & \\ \text { Brown-Forsythe } & 5.0542 & 2 & 9 & 0.0338 & \\ \text { Levene } & 7.0347 & 2 & 9 & 0.0145 & \\ \text { Bartlett } & 13.7289 & 2 & . & <.0001 & \end{array}$

Warning: Small sample sizes, Use Caution.

Welch Anova testing Means Equal, allowing Std Devs Not Equal

$\begin{array}{rrrr}\text { F Ratio } & \text { DFNum } & \text { DFDen } & \text { Prob > F } \\ 3.7643 & 2 & 5.3299 & 0.0957\end{array}$

Means Comparisons

Comparisons for all pairs using Tukey-Kramer HSD

q* Alpha

Abs(Dif)-LSD Cold Chem Peroxide Fusion Aqua Regia

$\begin{array}{lrrr}\text { Cold Chem } & -0.10441 & 0.02734 & 0.02809\end{array}$

Peroxide Fusion $\quad 0.02734 \quad-0.10441 \quad-0.1036$

$\begin{array}{llll}\text { Aqua Regia } & 0.02809 & -0.10366 & -0.10441\end{array}$

Positive values show pairs of means that are significantly different.

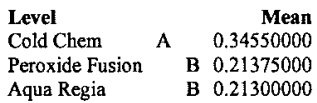

$\begin{array}{lll}\text { Aqua Regia } & \text { B } 0.21300000\end{array}$

Levels not connected by same letter are significantly different.
Oneway Analysis of Measurement (wt \%) By Prep Grouping=SRAT, Type=Product, Element $=$ Mn

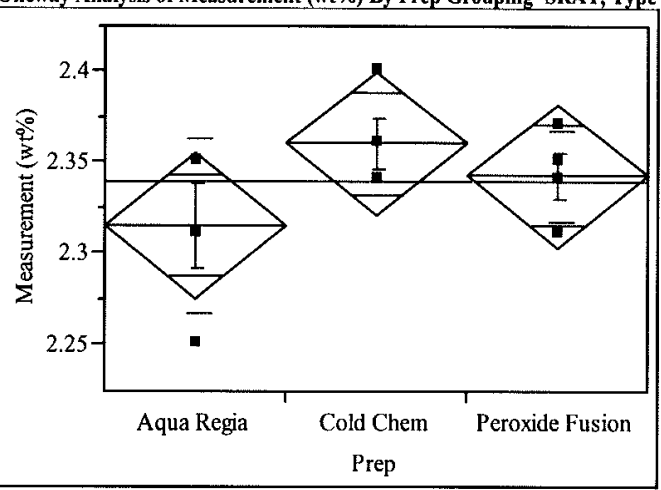

Oneway Anova

Summary of Fit

$\begin{array}{lr}\text { Rsquare } & 0.272777 \\ \text { Adj Rsquare } & 0.111172 \\ \text { Root Mean Square Error } & 0.034921 \\ \text { Mean of Response } & 2.339167 \\ \text { Observations (or Sum Wgts) } & 12\end{array}$

Analysis of Variance

Source DF Sum of Squares Mean Square F Ratio Prob $>$ F

$\begin{array}{lrrrrr}\text { Prep } & 2 & 0.00411667 & 0.002058 & 1.6879 & 0.2385\end{array}$

$\begin{array}{llll}\text { Error } & 9 & 0.01097500 & 0.001219\end{array}$

C. Total $11 \quad 0.01509167$

Means for Oneway Anova

Level Number Mean Std Error Lower 95\% Upper 95\%

$\begin{array}{llllll}\text { Aqua Regia } & 4 & 2.31500 & 0.01746 & 2.2755 & 2.3545\end{array}$

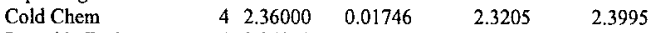

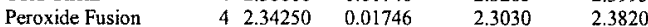

Std Error uses a pooled estimate of error variance

Means and Std Deviations

Level Number Mean Std Dev Std Err Mean Lower 95\% Upper 95\%

$\begin{array}{lllllll}\text { Aqua Regia } & 4 & 2.31500 & 0.047258 & 0.02363 & 2.2398 & 2.3902\end{array}$

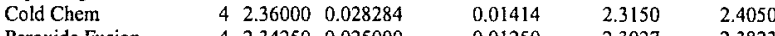

$\begin{array}{llllll}\text { Peroxide Fusion } & 4 & 2.34250 & 0.025000 & 0.01250 & 2.3027\end{array}$

Tests that the Variances are Equal

$\begin{array}{lrrrr}\text { Level } & \text { Count } & \text { Std Dev } & \text { MeanAbsbif to Mean } & \text { MeanAbsDif to Median } \\ \text { Aqua Regiz } & 4 & 0.0472582 & 0.0350000 & 0.0350000 \\ \text { Cold Chem } & 4 & 0.0282843 & 0.0200000 & 0.0200000 \\ \text { Peroxide Fusion } & 4 & 0.0250000 & 0.0175000 & 0.0175000\end{array}$

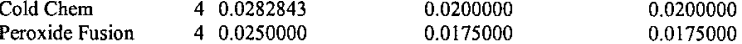

$\begin{array}{lrrrr}\text { Test } & \text { F Ratio } & \text { DFNum } & \text { DFDen } & \text { Prob }>\text { F } \\ \text { O'Brien[.5] } & 0.8493 & 2 & 9 & 0.4593 \\ \text { Brown-Forsythe } & 0.7049 & 2 & 9 & 0.5195 \\ \text { Levene } & 0.9923 & 2 & 9 & 0.4079 \\ \text { Bartlett } & 0.6334 & 2 & . & 0.5308\end{array}$

Warning: Small sample sizes. Use Caution.

Welch Anova testing Means Equal, allowing Std Devs Not Equal

F Ratio DFNum DFDen Prob $>$ F

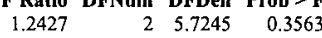

Means Comparisons

Comparisons for all pairs using Tukey-Kramer HSD

2.79201 Alpha

Abs(Dif)-LSD Cold Chem Peroxide Fusion Aqua Regia

$\begin{array}{llll}\text { Cold Chem } & -0.06894 & -0.05144 & -0.02394\end{array}$

$\begin{array}{llll}\text { Peroxide Fusion } & -0.05144 & -0.06894 & -0.04144\end{array}$

$\begin{array}{llll}\text { Aqua Regia } & -0.02394 & -0.04144 & -0.06894\end{array}$

Positive values show pairs of means that are significantly different.

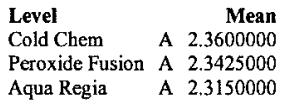

Aqua Regia A 23150000

Levels not connected by same letter are significantly different. 


\section{SRNL-STI-2011-00158, REVISION 0}

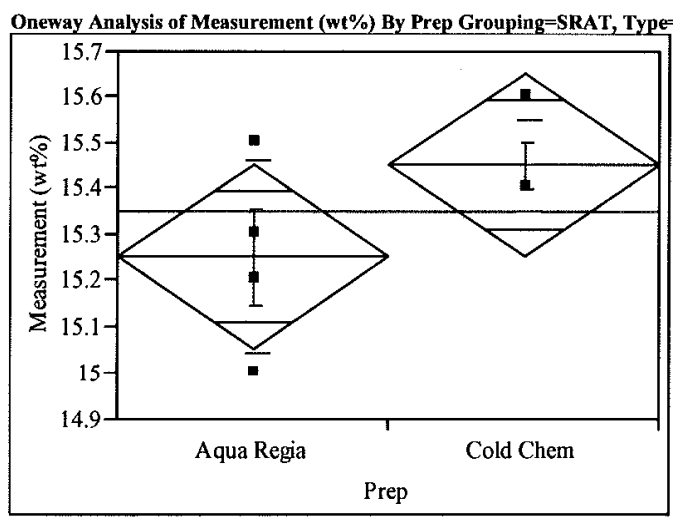

Missing Rows

Oneway Anova

Summary of Fit

Rsquare

Adj Rsquare

0.333333

Root Mean Square Error $\quad 0.163299$

Mean of Response $\quad 15.35$

Observations (or Sum Wgts)

Analysis of Variance

Source DF Sum of Squares Mean Square F Ratio Prob $>$ F

$\begin{array}{llllll}\text { Prep } & \mathrm{l} & 0.08000000 & 0.080000 & 3.0000 & 0.1340\end{array}$

Error $\quad \begin{array}{lll}6 & 0.16000000\end{array}$ 0.026667

Means for Oneway Anova

Level Number Mean Std Error Lower 95\% Upper 95\%

$\begin{array}{lrrrrr}\text { Level } & \text { Number } & \text { Mean } & \text { Std Error } & \text { Lower } 95 \% & \text { Upper 95\% } \\ \text { Aqua Regia } & 4 & 15.2500 & 0.08165 & 15.050 & 15.450\end{array}$

$\begin{array}{llllll}\text { Aqua Regia } & 4 & 15.2500 & 0.08165 & 15.050 & 15.450 \\ \text { Cold Chem } & 4 & 15.4500 & 0.08165 & 15.250 & 15.650\end{array}$

Peroxide Fusion $\begin{array}{lcc}4 & 15.4500 & 0.08165 \\ 0 & . & \end{array}$

Std Error uses a pooled estimate of error variance

Means and Std Deviations

Level Number Mean Std Dev Std Err Mean Lower 95\% Upper 95\%

$\begin{array}{lllll}\text { Aqua Regia } & 4 & 15.2500 & 0.208167 & 0.10408\end{array}$

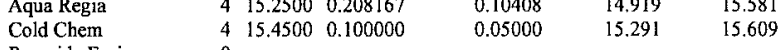

Peroxide Fusion

15.609

Tests that the Variances are Equal

$\begin{array}{lrrrr}\text { Level } & \text { Count } & \text { Std Dev } & \text { MeanAbsDif to Mean } & \text { MeanAbsDif to Median } \\ \text { Aqua Regia } & 4 & 0.2081666 & 0.1500000 & 0.1500000\end{array}$

$\begin{array}{lllll}\text { Cold Chem } & 4 & 0.1000000 & 0.0750000 & 0.0500000 \\ \text { Peroxide Fusion } & 0 & 0.0000000 & 0.0000000\end{array}$

Test F Ratio DFNum DFDen Prob $>$ F

$\begin{array}{lrrrr}\text { O'Brien[.5] } & 1.2308 & 1 & 6 & 0.3097\end{array}$

$\begin{array}{lllll}\text { Brown-Forsythe } & 1.7143 & 1 & 6 & 0.2383\end{array}$

$\begin{array}{lllll}\text { Levene } & 1.4211 & 1 & 6 & 0.2782\end{array}$

Warning: Small sample sizes. Use Caution.

Welch Anova testing Means Equal, allowing Std Devs Not Equal

F Ratio DFNum DFDen Prob $>$ F

$\begin{array}{rrrr}3.0000 & 1 & 4.3146 & 0.153\end{array}$

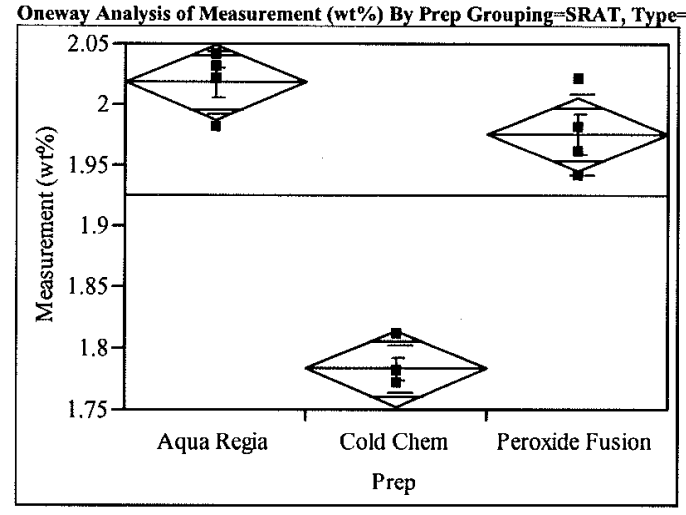

Oneway Anova

Summary of Fit

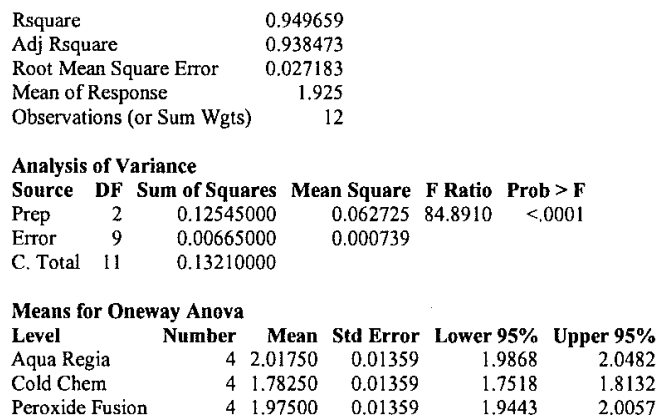

Std Error uses a pooled estimate of error variance

Means and Std Deviations

Level Number Mean Std Dev Std Err Mean Lower 95\% Upper 95\%

$\begin{array}{lllllrr}\text { Aqua Regia } & 4 & 2.01750 & 0.026300 & 0.01315 & 1.9757 & 2.0593\end{array}$

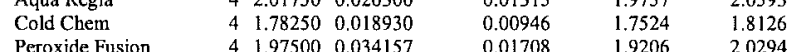

Tests that the Variances are Equal

Level Count Std Dev MeanAbsDif to Mean MeanAbsDif to Median

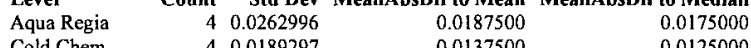

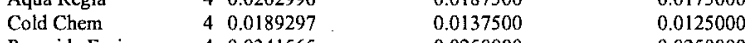

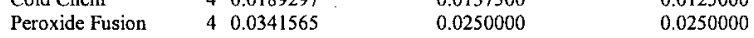

Test F Ratio DFNum DFDen Prob $>$ F

$\begin{array}{lrrrr}\text { O'Brien[.5] } & 0.5212 & 2 & 9 & 0.6107 \\ \text { Brown-Forsythe } & 0.5000 & 2 & 9 & 0.6224\end{array}$

$\begin{array}{lllll}\text { Levene } & 0.5755 & 2 & 9 & 0.5819\end{array}$

Warning: Small sample sizes. Use Caution.

Welch Anova testing Means Equal, allowing Std Devs Not Equal

F Ratio DFNum DFDen Prob $>$ F

$25.6776<0001$

Means Comparisons

Comparisons for all pairs using Tukey-Kramer HSD $\begin{array}{rr}\mathbf{q}^{*} & \text { Alpha } \\ 79201 & 0.05\end{array}$

Abs(Dif)-LSD Aqua Regia Peroxide Fusion Cold Chem

$\begin{array}{lrrr}\text { Aqua Regia } & -0.05367 & -0.01117 & 0.18133 \\ \text { Peroxide Fusion } & -0.01117 & -0.05367 & 0.13883\end{array}$

$\begin{array}{lrrr}\text { Peroxide Fusion } & -0.01117 & -0.05367 & 0.13883 \\ \text { Cold Chem } & 0.18133 & 0.13883 & -0.05367\end{array}$

Positive values show pairs of means that are significantly different.

$\begin{array}{lrr}\text { Level } & & \text { Mean } \\ \text { Aqua Regia } & \text { A } & 2.0175000 \\ \text { Peroxide Fusion } & \text { A } & 1.9750000 \\ \text { Cold Chem } & \text { B } & 1.7825000\end{array}$

Levels not connected by same letter are significantly different. 
SRNL-STI-2011-00158, REVISION 0

Oneway Analysis of Measurement (wt\%) By Prep Grouping=SRAT, Type=Product, Element=Si

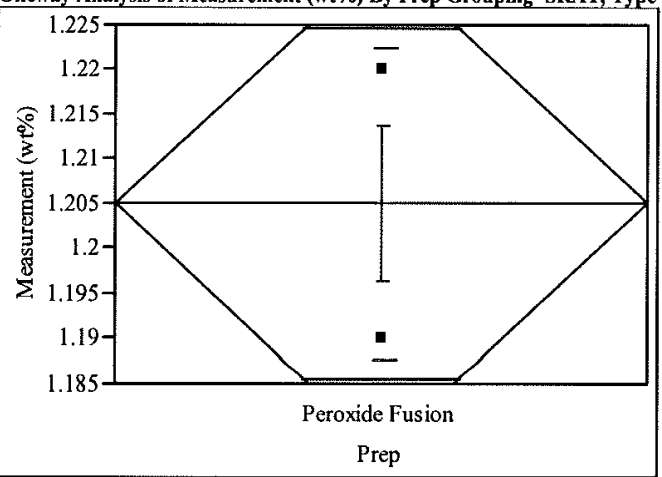

Missing Rows

Oneway Anova

Summary of Fit

Rsquare $\quad 1.11 \mathrm{e}-16$

Adj Rsquare $\quad 1.11 \mathrm{e}-16$

\begin{tabular}{ll} 
Root Mean Square Error $\quad 0.017321$ \\
\hline
\end{tabular}

Mean of Response $\quad 1.205$

Observations (or Sum Wgts)

Analysis of Variance

Source DF Sum of Squares Mean Square F Ratio Prob > F

$\begin{array}{lll}\text { Prep } & 0 & 0.00000000\end{array}$

Error $3 \quad 0.00090000$

$\begin{array}{lll}\text { C. Total } 3 & 0.00090000\end{array}$

Means for Oneway Anova

Level Number Mean Std Error Lower 95\% Upper 95\%

Aqua Regia

Cold Chem 0

Peroxide Fusion

$\begin{array}{lllll}4 & 1.20500 & 0.00866 & 1.1774 & 1.2326\end{array}$

Std Error uses a pooled estimate of error variance

Means and Std Deviations

Level Number

Aqua Regia

Cold Chem

0

Mean Std Dev Std Err Mean Lower 95\% Upper 95\%

Peroxide Fusion

$41.20500 \quad 0.017321$

0.00866

1.1774

1.2326

Tests that the Variances are Equal

$\begin{array}{lrrrr}\text { Level } & \text { Count } & \text { Std Dev } & \text { MeanAbsDif to Mean } & \text { MeanAbsDif to Median } \\ \text { Aqua Regia } & 0 & \cdot & 0.0000000 & 0.0000000 \\ \text { Cold Chem } & 0 & : & 0.0000000 & 0.0000000 \\ \text { Peroxide Fusion } & 4 & 0.0173205 & 0.0150000 & 0.0150000\end{array}$

Test F Ratio DFNum DFDen Prob $>$ F

O'Brien[.5]

Brown-Fors

Bartlet

$\begin{array}{lll}0 & 3 & \text {. } \\ 0 & 3 & \text {. } \\ 0 & 3 & \\ 0 & 3 & \text {. }\end{array}$

Warning: Small sample sizes. Use Caution.

Welch Anova testing Means Equal, allowing Std Devs Not Equal

F Ratio DFNum DFDen Prob $>$ F

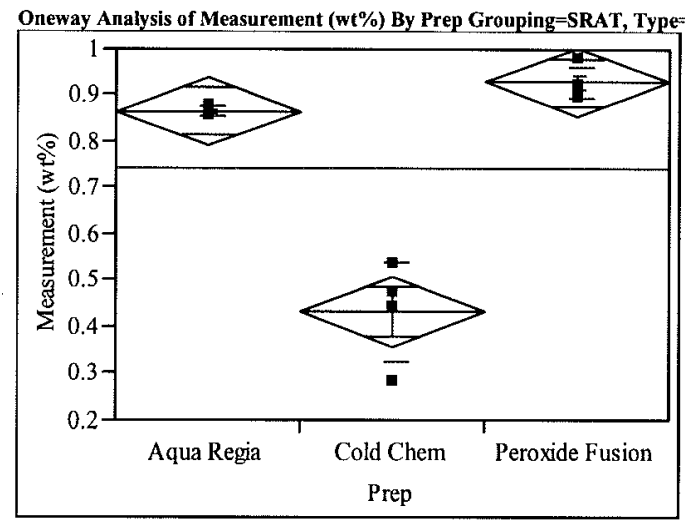

Oneway Anova

Summary of Fit

Rsquare

Adj Rsquare

0.937225

0.923275

Root Mean Square Error $\quad 0.06580$

Mean of Response $\quad 0.74075$

Observations (or Sum Wgts)

12

Analysis of Variance

Source DF Sum of Squares Mean Square F Ratio Prob $>$ F

$\begin{array}{lllllll}\text { Prep } & 2 & 0.58181450 & 0.290907 & 67.1846 & <.000\end{array}$

$\begin{array}{lrrr}\text { Error } 9 & 0.03896975 & 0.004330\end{array}$

C. Total $11 \quad 0.62078425$

Means for Oneway Anova

Level Number Mean Std Error Lower 95\% Upper 95\%

$\begin{array}{lrrrrr}\text { Aqua Regia } & \mathbf{4} & 0.863750 & 0.03290 & 0.78932 & 0.9382\end{array}$

$\begin{array}{llllll}\text { Aqua Regia } & \mathbf{4} & 0.863750 & 0.03290 & 0.78932 & 0.9382 \\ \text { Cold Chem } & 4 & 0.431500 & 0.03290 & 0.35707 & 0.5059\end{array}$

$\begin{array}{llllll}\text { Peroxide Fusion } & 4 & 0.431500 & 0.03290 & 0.35707 & 0.5059 \\ & 4 & 0.927000 & 0.03290 & 0.85257 & 1.0014\end{array}$

Std Emor uses a pooled estimate of error variance

Means and Std Deviations

Level Number Mean Std Dev Std Err Mean Lower 95\% Upper 95\%

$\begin{array}{lllllll}\text { Aqua Regia } & 4 & 0.863750 & 0.010012 & 0.00501 & 0.84782 & 0.87968\end{array}$

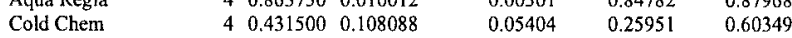

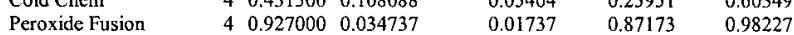

Tests that the Variances are Equal

$\begin{array}{lrrrr}\text { Level } & \text { Count } & \text { Std Dev } & \text { MeanAbsDif to Mean } & \text { MeanAbsDif to Median } \\ \text { Aqua Regia } & 4 & 0.0100125 & 0.0072500 & 0.0072500\end{array}$

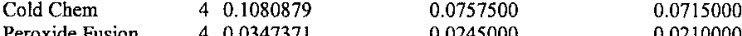

$\begin{array}{llll}\text { Peroxide Fusion } & 40.0347371 & 0.0245000 & 0.0210000\end{array}$

Test F Ratio DFNum DFDen Prob $>$ F

$\begin{array}{lrrrr}\text { O'Brien[.5] } & 1.5924 & 2 & 9 & 0.2558\end{array}$

$\begin{array}{lllll}\text { Brown-Forsythe } & 2.1346 & 2 & 9 & 0.1743 \\ \text { Levene } & 3.4087 & 2 & 9 & 0.0791\end{array}$

$\begin{array}{llll}\text { Bartlett } & 5.2921 & 2 & 0.0050\end{array}$

Warning: Small sample sizes. Use Caution

Welch Anova testing Means Equal, allowing Std Devs Not Equal

F Ratio DFNum DFDen Prob $>$ F

$\begin{array}{rrrr}33.4320 & 2 & 4.3361 & 0.0023\end{array}$

Means Comparisons

Comparisons for all pairs using Tukey-Kramer HSD $\mathbf{q}^{\mathbf{q}} \mathbf{q}^{\star}$ Alpha

$\begin{array}{lrrr}\text { Abs(Dif)-LSD } & \text { Peroxide Fusion } & \text { Aqua Regia } & \text { Cold Chem } \\ \text { Peroxide Fusion } & -0.12991 & -0.06666 & 0.36559 \\ \text { Aqua Regia } & -0.06666 & -0.12991 & 0.30234 \\ \text { Cold Chem } & 0.36559 & 0.30234 & -0.12991\end{array}$

Positive values show pairs of means that are significantly different.

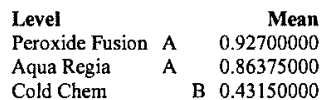

Levels not connected by same letter are significantly different. 
SRNL-STI-2011-00158, REVISION 0

Oneway Analysis of Measurement (wt\%) By Prep Grouping=SRAT, Type=Product, Element=Ti

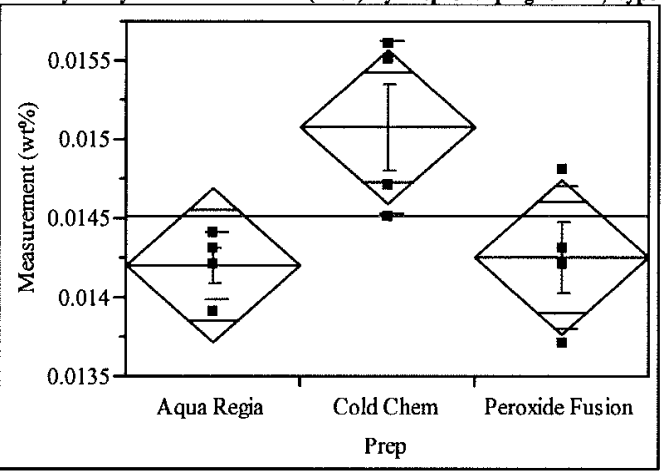

Oneway Anova

Summary of Fit

Rsquare

Adj Rsquare

0.535211

0.431925

0.000432

$\begin{array}{lr}\text { Mean of Response } & 0.014508 \\ \text { Observations (or Sum Wgts) } & 12\end{array}$

Observations (or Sum Wht

Analysis of Variance

Source DF Sum of Squares Mean Square F Ratio Prob $>$ F

$\begin{array}{lrrrrr}\text { Prep } & 2 & 1.93167 \mathrm{e}-6 & 9.6583 \mathrm{e}-7 & 5.1818 & 0.0318\end{array}$

$\begin{array}{lrrr}\text { Enor } & 9 & 1.6775 \mathrm{e}-6 & 1.8639 \mathrm{e}-7 \\ \text { C. Total } & 11 & 3.60917 \mathrm{e}-6 & \end{array}$

Means for Oneway Anova

Level Number Mean Std Error Lower 95\% Upper 95\%

$\begin{array}{lrllll}\text { Aqua Regia } & 4 & 0.014200 & 0.00022 & 0.01371 & 0.01469\end{array}$

$\begin{array}{llllll}\text { Aqua Regia } & 4 & 0.014200 & 0.00022 & 0.01371 & 0.01469 \\ \text { Cold Chem } & 4 & 0.015075 & 0.00022 & 0.01459 & 0.01556\end{array}$

$\begin{array}{llllll}\text { Cold Chem } & 4 & 0.015075 & 0.00022 & 0.01459 & 0.01556 \\ \text { Peroxide Fusion } & 4 & 0.014250 & 0.00022 & 0.01376 & 0.01474\end{array}$

Std Error uses a pooled estimate of error variance

Means and Std Deviations

Level Number Mean Std Dev Std Err Mean Lower 95\% Upper 95\%

$\begin{array}{lllllll}\text { Aqua Regia } & 4 & 0.014200 & 0.000216 & 0.00011 & 0.01386 & 0.01454\end{array}$

$\begin{array}{lllllll}\text { Cold Chem } & 4 & 0.015075 & 0.000556 & 0.00028 & 0.01419 & 0.01596\end{array}$

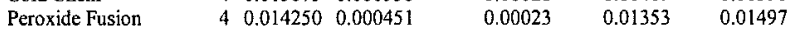

Tests that the Variances are Equal

\begin{tabular}{lrrrrr} 
Level & Count & Std Dev & MeanAbsDif to Mean & MeanAbsDif to Median \\
Aqua Regia & 4 & 0.0002160 & & 0.0001500 & 0.0001500 \\
Cold Chem & 4 & 0.0005560 & & 0.0004750 & 0.0004750 \\
Peroxide Fusion & 4 & 0.0004509 & & 0.0003000 & 0.0003000 \\
& \multicolumn{5}{l}{} \\
Test & F Ratio & DFNum & DFDen & Prob > F & \\
O'Brien[.5] & 1.9235 & 2 & 9 & 0.2016 & \\
Brown-Forsythe & 2.8222 & 2 & 9 & 0.1118 & \\
Levene & 2.9308 & 2 & 9 & 0.1047 & \\
Bartlett & 1.0344 & 2 &. & 0.3554 &
\end{tabular}

Warning: Small sample sizes. Use Caution.

Welch Anova testing Means Equal, allowing Std Devs Not Equal

F Ratio DFNum DFDen Prob $>$ F

$\begin{array}{rrrr}3.8374 & 2 & 5.1139 & 0.0960\end{array}$

Means Comparisons

Comparisons for all pairs using Tukey-Kramer HSD

$\mathbf{q}^{\star}$ Alpha

Abs(Dif)-LSD Cold Chem Peroxide Fusion Aqua Regia

$\begin{array}{llll}\text { Cold Chem } & -0.00085 & -0.00003 & 0.00002\end{array}$

$\begin{array}{llll}\text { Peroxide Fusion } & -0.00003 & -0.00085 & -0.00080\end{array}$

$\begin{array}{llll}\text { Aqua Regia } & 0.00002 & -0.00080 & -0.00085\end{array}$

Positive values show pairs of means that are significantly different.

Level Mean

Cold Chem A 0.01507500

Peroxide Fusion A B 0.01425000

$\begin{array}{lll}\text { Aqua Regia } & \text { B } 0.01420000\end{array}$

Levels not connected by same letter are significantly different.
Oneway Analysis of Measurement (wt \%) By Prep Grouping=SRAT, Type=Product, Element=U

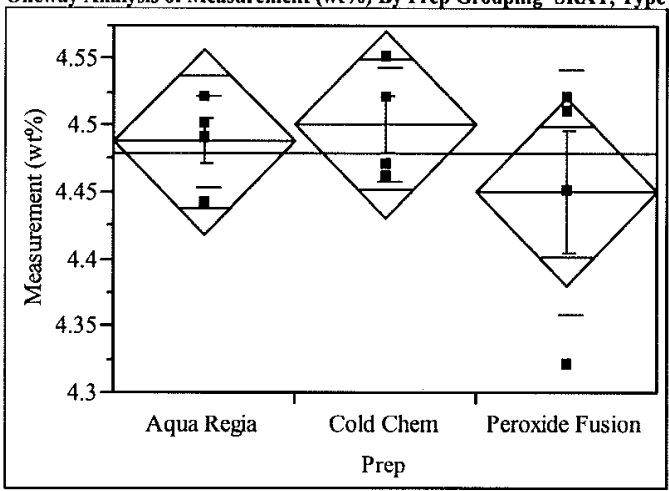

Oneway Anova

Summary of Fit

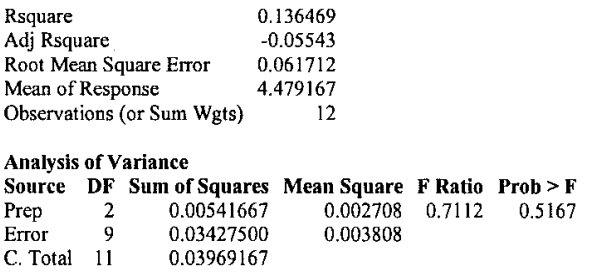

Means for Oneway Anova

Level Number Mean Std Error Lower 95\% Upper 95\%

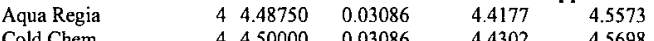

Peroxide Fusion $\quad 4 \quad 4.45000 \quad 0.03086 \quad 4.3802 \quad 4.5198$

Std Error uses a pooled estimate of error variance

Means and Std Deviations

Level Number Mean Std Dev Std Err Mean Lower 95\% Upper 95\%

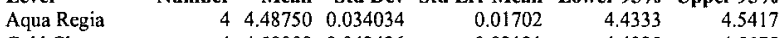

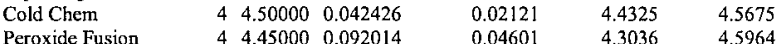

Tests that the Variances are Equal

$\begin{array}{lrrrr}\text { Level } & \text { Count } & \text { Std Dev } & \text { MeanAbsDif to Mean } & \text { MeanAbsDif to Median } \\ \text { Aqua Regia } & 4 & 0.0340343 & 0.0237500 & 0.0225000 \\ \text { Cold Chem } & 4 & 0.0424264 & 0.0350000 & 0.0350000 \\ \text { Peroxide Fusion } & 4 & 0.0920145 & 0.0650000 & 0.0650000\end{array}$

$\begin{array}{lrrrr}\text { Test } & \text { F Ratio } & \text { DFNum } & \text { DFDen } & \text { Prob > F } \\ \text { O'Brien[.5] } & 1.2711 & 2 & 9 & 0.3264 \\ \text { Brown-Forsythe } & 1.1948 & 2 & 9 & 0.3466 \\ \text { Levene } & 1.6018 & 2 & 9 & 0.2540 \\ \text { Bartlett } & 1.4902 & 2 & . & 0.2253\end{array}$

Warning: Small sample sizes. Use Caution.

Welch Anova testing Means Equal, allowing Std Devs Not Equal

F Ratio DFNum DFDen Prob $>$ F

$\begin{array}{llll}0.4439 & 2 & 5.5094 & 0.6626\end{array}$

Means Comparisons

Comparisons for all pairs using Tukey-Kramer HSD

$2.79201 \quad 0.05$

Abs(Dif)-LSD Cold Chem Aqua Regia Peroxide Fusion

$\begin{array}{lrrr}\text { Cold Chem } & -0.12183 & -0.10933 & -0.07183\end{array}$

$\begin{array}{llll}\text { Aqua Regia } & -0.10933 & -0.12183 & -0.08433\end{array}$

$\begin{array}{llll}\text { Peroxide Fusion } & -0.07183 & -0.08433 & -0.12183\end{array}$

Positive values show pairs of means that are significantly different.

$\begin{array}{lr}\text { Level } & \text { Mean } \\ \text { Cold Chem } & \text { A } 4.5000000\end{array}$

Cold Chem A 4.5000000

Aqua Regia A 4.4875000
Peroxide Fusion

Levels not connected by same letter are significantly different. 
SRNL-STI-2011-00158, REVISION 0

Oneway Analysis of Measurement (wt $\%$ ) By Prep Grouping=SRAT, Type=Product, Element $=\mathbf{Z r}$

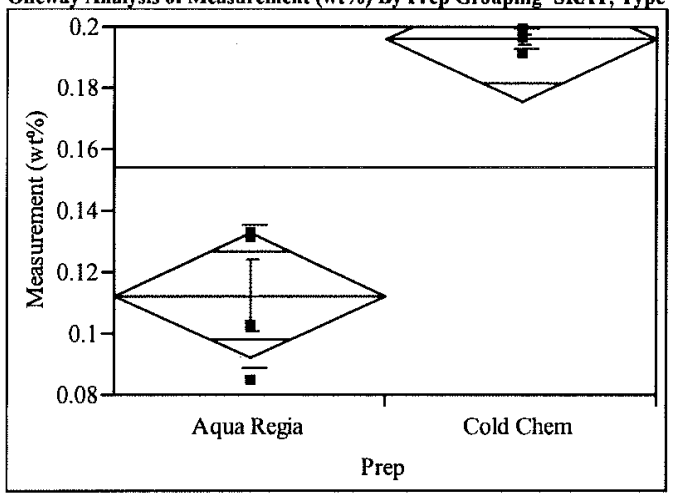

Missing Rows

Oneway Anova

Summary of Fit

Rsquare $\quad 0.89277$

Adj Rsquare $\quad 0.874899$

Root Mean Square Error $\quad 0.016703$

$\begin{array}{lr}\text { Mean of Response } & 0.154013 \\ \text { Observations (or Sum Wgts) } & 8\end{array}$

Analysis of Variance

Source DF Sum of Squares Mean Square F Ratio Prob $>$ F

$\begin{array}{lllllll}\text { Prep } & 1 & 0.01393615 & 0.013936 & 49.9546 & 0.0004\end{array}$

$\begin{array}{llll}\text { Error } & 6 & 0.00167386 & 0.000279\end{array}$

C. Total $7 \quad 0.01561001$

$\begin{array}{lrrrrr}\text { Means for Oneway Anova } & & & & \\ \text { Level } & \text { Number } & \text { Mean } & \text { Std Error } & \text { Lower 95\% } & \text { Upper 95\% } \\ \text { Aqua Regia } & 4 & 0.112275 & 0.00835 & 0.09184 & 0.13271 \\ \text { Cold Chem } & 4 & 0.195750 & 0.00835 & 0.17532 & 0.21618\end{array}$

Peroxide Fusion

Std Error uses a pooled estimate of error variance

$\begin{array}{lrrrrrr}\text { Means and Std Deviations } & & & & & \\ \text { Level } & \text { Number } & \text { Mean } & \text { Std Dev } & \text { Std Err Mean } & \text { Lower 95\% } & \text { Upper 95\% } \\ \text { Aqua Regia } & 4 & 0.112275 & 0.023375 & 0.01169 & 0.07508 & 0.14947 \\ \text { Cold Chem } & 4 & 0.195750 & 0.003403 & 0.00170 & 0.19033 & 0.20117\end{array}$

Peroxide Fusion

Tests that the Variances are Equal

$\begin{array}{lrrrrr}\text { Level } & \text { Count } & \text { Std Dev } & \text { MeanAbsDif to Mean } & \text { MeanAbsDif to Median } \\ \text { Aqua Regia } & 4 & 0.0233745 & & 0.0192250 & 0.0192250 \\ \text { Cold Chem } & 4 & 0.0034034 & & 0.0023750 & 0.0022500 \\ \text { Peroxide Fusion } & 0 & . & & 0.0000000 & 0.0000000 \\ & & & & & \\ \text { Test } & \text { F Ratio } & \text { DFNum } & \text { DFDen } & \text { Prob }>\text { F } & \\ \text { O'Brien[.5] } & 5.0576 & 1 & 6 & 0.0655 & \\ \text { Brown-Forsythe } & 13.8947 & 1 & 6 & 0.0098 & \\ \text { Levene } & 19.7063 & 1 & 6 & 0.0044 & \\ \text { Bartlett } & 6.4527 & 1 & . & 0.0111 & \end{array}$

Warning: Small sample sizes. Use Caution.

Welch Anova testing Means Equal, allowing Std Devs Not Equal

F Ratio DFNum DFDen Prob $>$ F

$49.9546 \quad \begin{array}{rrr}3.1271 & 0.005\end{array}$

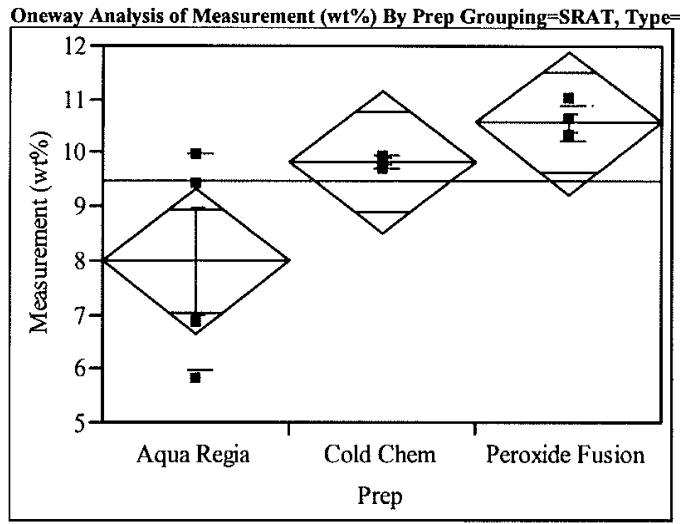

Oneway Anova

Sunmary of Fit

Adj Rsquare

0.530885

0.426637

ror $\quad 1.176518$

$\begin{array}{lr}\text { Mean of Response } & 9.453333 \\ \text { Observations (or Sum Wgts) } & 12\end{array}$

Analysis of Variance

Source DF Sum of Squares Mean Square F Ratio Prob $>$ F

$\begin{array}{llllll}\text { Prep } & 2 & 14.098117 & 7.04906 & 5.0925 & 0.0332\end{array}$

$\begin{array}{llll}\text { Error } & 9 & 12.457750 & 1.38419\end{array}$

C. Total $11 \quad 26.555867$

Means for Oneway Anova

Level Number Mean Std Error Lower 95\% Upper 95\%

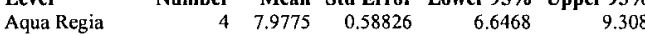

$\begin{array}{lrrrrr}\text { Aqua Rem } & 4 & 7.9775 & 0.58826 & 6.6468 & 9.308 \\ \text { Cold Chem } & 4 & 9.8325 & 0.58826 & 8.5018 & 11.163\end{array}$

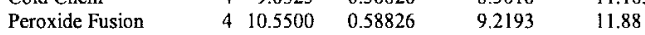

Std Error uses a pooled estimate of error variance

Means and Std Deviations

$\begin{array}{lrrrrrr}\text { Level } & \text { Number } & \text { Mean } & \text { Std Dev } & \text { Std Err Mean } & \text { Lower 95\% } & \text { Upper 95\% } \\ \text { Aqua Regia } & 4 & 7.9775 & 200686 & 1.0034 & 4.784 & 11.171\end{array}$

$\begin{array}{lllllll}\text { Aqua Regia } & 4 & 7.9775 & 2.00686 & 1.0034 & 4.784 & 11.171 \\ \text { Cold Chem } & 4 & 9.8325 & 0.12285 & 0.0614 & 9.637 & 10.028\end{array}$

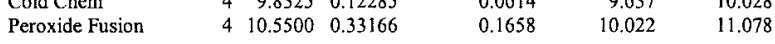

Tests that the Variances are Equal

$\begin{array}{lrrrr}\text { Level } & \text { Count } & \text { Std Dev } & \text { MeanAbsDif to Mean } & \text { MeanAbsDif to Median } \\ \text { Aqua Regia } & 4 & 2.006861 & 1.687500 & 1.687500 \\ \text { Cold Chem } & 4 & 0.122848 & 0.091250 & 0.072500 \\ \text { Peroxide Fusion } & 4 & 0.331662 & 0.250000 & 0.250000\end{array}$

Test F Ratio DFNum DFDen Prob $>$ F

$\begin{array}{lllll}\text { O'Brien[.5] } & 8.5469 & 2 & 9 & 0.0083\end{array}$

$\begin{array}{llll}\text { Brown-Forsythe } 30.6007 & 2 & 9 & <.0001\end{array}$

$\begin{array}{lllll}\text { Levene } & 35.5155 & 2 & 9 & <.0001\end{array}$

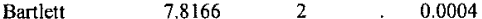

Warning: Small sample sizes. Use Caution.

Welch Anova testing Means Equal, allowing Std Devs Not Equal

F Ratio DFNum DFDen Prob $>$ F

$\begin{array}{llll}8.7908 & 2 & 4.4877 & 0.0280\end{array}$

Means Comparisons

Comparisons for all pairs using Tukey-Kramer HSD

$q^{*}$ Alpha

Abs(Dif)-LSD Peroxide Fusion Cold Chem Aqua Regia

$\begin{array}{llll}\text { Peroxide Fusion } & -2.3227 & -1.6052 & 0.2498\end{array}$

$\begin{array}{llll}\text { Cold Chem } & -1.6052 & -2.3227 & -0.4677\end{array}$

$\begin{array}{llll}\text { Aqua Regia } & 0.2498 & -0.4677 & -2.3227\end{array}$

Positive values show pairs of means that are significantly different.

Level Mean

Peroxide Fusion A 10.550000

Cold Chem A B 9.832500

Aqua Regia $\quad$ B 7.977500

Levels not connected by same letter are significantly different. 
SRNL-STI-2011-00158, REVISION 0

Oneway Analysis of Measurement (wt \%) By Prep Grouping $=$ SRAT, Type=Receipt, Element=B

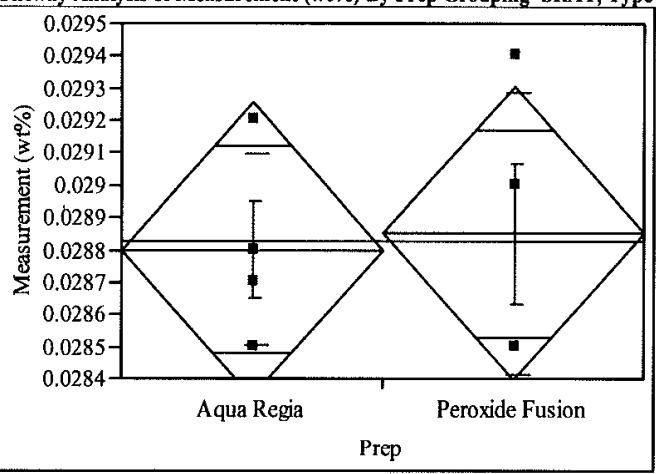

Missing Rows

Oneway Anova

Summary of Fit

Rsquare $\quad 0.005988$

Adj Rsquare $\quad-0.15968$

Root Mean Square Error $\quad 0.000372$

Mean of Response $\quad 0.028825$

Observations (or Sum Wgts)

Analysis of Variance

Source DF Sum of Squares Mean Square F Ratio Prob > F

$\begin{array}{lrrrrr}\text { Prep } & 1 & 5 \mathrm{e}-9 & 5 \mathrm{e}-9 & 0.0361 & 0.8555\end{array}$

$\begin{array}{lrrr}\text { Error } & 6 & 0.00000083 & 1.3833 \mathrm{e}-7 \\ \text { C. Total } & 7 & 8.35 \mathrm{e}-7 & \end{array}$

$\begin{array}{lrrrrr}\text { Means for Oneway Anova } & & & & \\ \text { Level } & \text { Number } & \text { Mean } & \text { Std Error } & \text { Lower 95\% } & \text { Upper 95\% } \\ \text { Aqua Regia } & 4 & 0.028800 & 0.00019 & 0.02834 & 0.02926 \\ \text { Cold Chem } & 0 & & & & \\ \text { Peroxide Fusion } & 4 & 0.028850 & 0.00019 & 0.02839 & 0.02931\end{array}$

Std Error uses a pooled estimate of error variance

$\begin{array}{lrrrrrr}\text { Means and Std Deviations } & & & & & \\ \text { Level } & \text { Number } & \text { Mean } & \text { Std Dev } & \text { Std Err Mean } & \text { Lower 95\% } & \text { Upper 95\% } \\ \text { Aqua Regia } & 4 & 0.028800 & 0.000294 & 0.00015 & 0.02833 & 0.02927 \\ \text { Cold Chem } & 0 & . & & & & \\ \text { Peroxide Fusion } & 4 & 0.028850 & 0.000436 & 0.00022 & 0.02816 & 0.02954\end{array}$

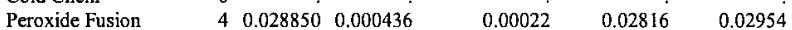

Tests that the Variances are Equal

\begin{tabular}{|c|c|c|c|c|c|}
\hline Level & Count & Std Dev & \multicolumn{2}{|c|}{ MeanAbsDif to Mean } & MeanAbsDif to Median \\
\hline Aqua Regia & 4 & 0.0002944 & & 0,0002000 & 0.0002000 \\
\hline Cold Chem & 0 & & & 0.0000000 & 0.0000000 \\
\hline Peroxide Fusion & 4 & 0.0004359 & & 0.0003500 & 0.0003500 \\
\hline Test & F Ratio & DFNum & DFDen & Prob $>F$ & \\
\hline O'Brien[.5] & 0.7994 & 1 & 6 & 0.4057 & \\
\hline Brown-Forsythe & 1.1739 & 1 & 6 & 0.3202 & \\
\hline Levene & 1.5000 & 1 & 6 & 0.2666 & \\
\hline Bartlett & 0.3863 & 1 & & 0.5342 & \\
\hline
\end{tabular}

Warning: Small sample sizes. Use Caution.

Welch Arova testing Means Equal, allowing Std Devs Not Equal

F Ratio DFNum DFDen Prob $>$ F

$\begin{array}{llll}0.0361 & 5.2655 & 0.8563\end{array}$
Oneway Analysis of Measurement (wt\%) By Prep Grouping=SRAT, Type=Receipt, Element=Ca

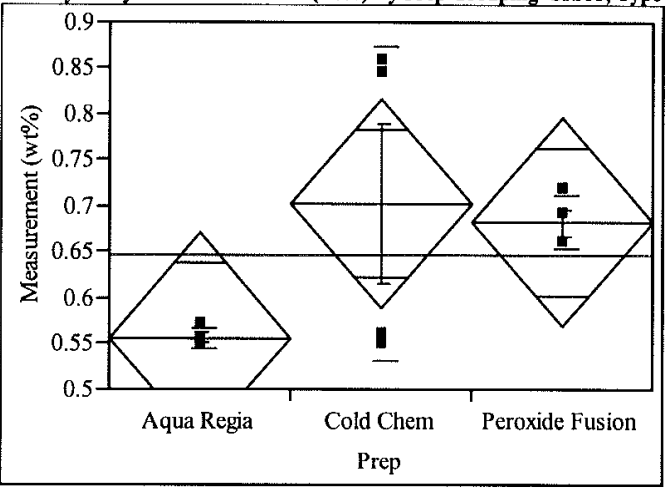

Oneway Anova

Summary of Fit

$\begin{array}{lr}\text { Rsquare } & 0.353721 \\ \text { Adj Rsquare } & 0.210104 \\ \text { Root Mean Square Error } & 0.100802 \\ \text { Mean of Response } & 0.646833 \\ \text { Observations (or Sum Wgts) } & 12\end{array}$

Analysis of Variance

Source DF Sum of Squares Mean Square F Ratio Prob $>$ F

$\begin{array}{lrrrrr}\text { Prep } & 2 & 0.05005217 & 0.025026 & 2.4629 & 0.1402\end{array}$

$\begin{array}{llll}\text { Error } & 9 & 0.09144950 & 0.010161\end{array}$

C. Total $11 \quad 0.14150167$

Means for Oneway Anova

Level Number Mean Std Error Lower 95\% Upper 95\%

$\begin{array}{lllllll}\text { Aqua Regia } & 4 & 0.556250 & 0.05040 & 0.44223 & 0.67027\end{array}$

$\begin{array}{llllll}\text { Cold Chem } & 4 & 0.702250 & 0.05040 & 0.58823 & 0.81527\end{array}$

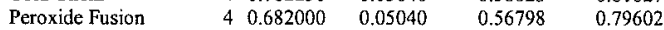

Std Error uses a pooled estimate of error variance

Means and Std Deviations

Level Number Mean Std Dev Std Err Mean Lower 95\% Upper 95\%

$\begin{array}{lllllll}\text { Aqua Regia } & 4 & 0.556250 & 0.010905 & 0.00545 & 0.53890 & 0.57360\end{array}$

$\begin{array}{lllllll}\text { Cold Chem } & 4 & 0.702250 & 0.171890 & 0.08595 & 0.42873 & 0.97577\end{array}$

$\begin{array}{lllllll}\text { Peroxide Fusion } & 4 & 0.682000 & 0.028601 & 0.01430 & 0.63649 & 0.72751\end{array}$

Tests that the Variances are Equal

$\begin{array}{lrrrr}\text { Level } & \text { Count } & \text { Std Dev } & \text { MeanAbsDif to Mean } & \text { MeanAbsDif to Median } \\ \text { Aqua Regia } & 4 & 0.0109049 & 0.0078750 & 0.0072500 \\ \text { Cold Chem } & 4 & 0.1718902 & 0.1487500 & 0.1487500 \\ \text { Peroxide Fusion } & 4 & 0.0286007 & 0.0230000 & 0.0230000\end{array}$

$\begin{array}{lrrrr}\text { Test } & \text { F Ratio } & \text { DFNum } & \text { DFDen } & \text { Prob }>\text { F } \\ \text { O'Brien[.5] } & 292.1797 & 2 & 9 & <.0001 \\ \text { Brown-Forsythe } & 256.9736 & 2 & 9 & <.0001 \\ \text { Levene } & 371.7718 & 2 & 9 & <.0001 \\ \text { Bartlett } & 7.7080 & 2 & . & 0.0004\end{array}$

Warning: Small sample sizes. Use Caution.

Welch Anova testing Means Equal, allowing Std Devs Not Equal

F Ratio DFNum DFDen Prob $>$ F

$\begin{array}{lrrr}30.4041 & 2 & 4.5123 & 0.0024\end{array}$

Means Comparisons

Comparisons for all pairs using Tukey-Kramer HSD $\mathrm{q}^{*}$ Alpha

Abs(Dif)-LSD Cold Chem Peroxide Fusion Aqua Regia

$\begin{array}{llll}\text { Cold Chem } & -0.19901 & -0.17876 & -0.05301\end{array}$

Peroxide Fusion $\quad-0.17876 \quad-0.19901-0.07326$

$\begin{array}{llll}\text { Aqua Regia } & -0.05301 & -0.07326 & -0.19901\end{array}$

Positive values show pairs of means that are significantly different

$\begin{array}{lrr}\text { Level } & \text { Mean } \\ \text { Cold Chem } & \text { A } & 0.70225000 \\ \text { Peroxide Fusion } & \text { A } & 0.68200000 \\ \text { Aqua Regia } & \text { A } & 0.55625000\end{array}$

Levels not connected by same letter are significantly different. 


\section{SRNL-STI-2011-00158, REVISION 0}

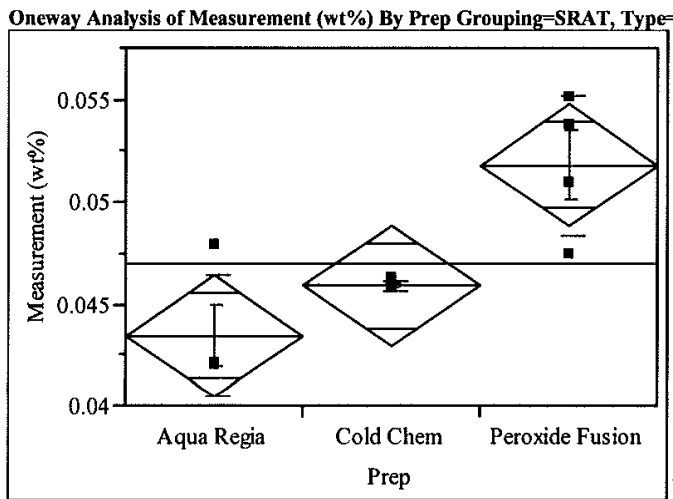

Oneway Anova

Summary of Fit

Rsquare $\quad 0.705$

Adj Rsquare $\quad 0.639688$

Root Mean Square Error $\quad 0.002614$

Mean of Response $\quad 0.047033$

Observations (or Sum Wgts) $\quad 12$

Analysis of Variance

Source DF Sum of Squares Mean Square F Ratio Prob $>$ F

$\begin{array}{lllllll}\text { Prep } & 2 & 0.00014715 & 0.000074 & 10.7646 & 0.0041\end{array}$

$\begin{array}{llll}\text { Ertor } & 9 & 0.00006151 & 6.835 \mathrm{e}-6\end{array}$

C. Total $11 \quad 0.00020867$

Means for Oneway Anova

Level Number Mean Std Error Lower 95\% Upper 95\%

$\begin{array}{lrrrrr}\text { Aqua Regia } & 4 & 0.043425 & 0.00131 & 0.04047 & 0.04638\end{array}$

$\begin{array}{llllll}\text { Cold Chem } & 4 & 0.045900 & 0.00131 & 0.04294 & 0.04886\end{array}$

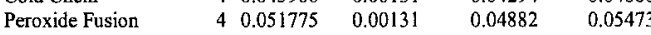

Std Enor uses a pooled estimate of error variance

$\begin{array}{lrrrrrr}\begin{array}{l}\text { Means and Std Deviations } \\ \text { Level }\end{array} & \text { Number } & \text { Mean } & \text { Std Dev } & \text { Std Err Mean } & \text { Lower 95\% } & \text { Upper 95\% } \\ \text { Aqua Regia } & 4 & 0.043425 & 0.002984 & 0.00149 & 0.03868 & 0.04817 \\ \text { Cold Chem } & 4 & 0.045900 & 0.000216 & 0.00011 & 0.04556 & 0.04624 \\ \text { Peroxide Fusion } & 4 & 0.051775 & 0.003399 & 0.00170 & 0.04637 & 0.05718\end{array}$

Tests that the Variances are Equa

\begin{tabular}{lrrrrr} 
Level & Count & Std Dey & MeanAbsDif to Mean & MeanAbsDif to Median \\
Aqua Regia & 4 & 0.0029837 & 0.0022375 & 0.0015250 \\
Cold Chem & 4 & 0.0002160 & & 0.0001500 & 0.0001500 \\
Peroxide Fusion & 4 & 0.0033994 & & 0.0026250 & 0.0026250 \\
& \multicolumn{5}{l}{} \\
Test & F Ratio & DFNum & DFDen & Prob > F & \\
O'Brien[.5] & 1.0696 & 2 & 9 & 0.3830 & \\
Brown-Forsythe & 1.6104 & 2 & 9 & 0.2524 & \\
Levene & 4.6109 & 2 & 9 & 0.0418 & \\
Bartlett & 5.4837 & 2 &. & 0.0042 &
\end{tabular}

Warning: Small sample sizes. Use Caution.

Welch Anova testing Means Equal, allowing Std Devs Not Equal

F Ratio DFNum DFDen Prob $>$ F

$\begin{array}{lllll}6.3039 & 2 & 4.0369 & 0.0573\end{array}$

Means Comparisons

Comparisons for all pairs using Tukey-Kramer HSD

$\begin{array}{rr}\mathbf{q}^{*} & \text { Alpha } \\ 2.79201 & 0.05\end{array}$

Abs(Dif)-LSD Peroxide Fusion Cold Chem Aqua Regia

$\begin{array}{llll}\text { Peroxide Fusion } & -0.00516 & 0.00071 & 0.00319\end{array}$

$\begin{array}{llll}\text { Cold Chem } & 0.00071 & -0.00516 & -0.00269\end{array}$

$\begin{array}{llll}\text { Aqua Regia } & 0.00319 & -0.00269 & -0.00516\end{array}$

Positive values show pairs of means that are significantly different.

Mean
Peroxide Fusion A $\quad 0.05177500$

Cold Chem A 0.04590000

Aqua Regia B 0.04342500

Levels not connected by same letter are significantly different.
Oneway Analysis of Measurement (wt\%) By Prep Grouping=SRAT, Type=Receipt, Element=Cu

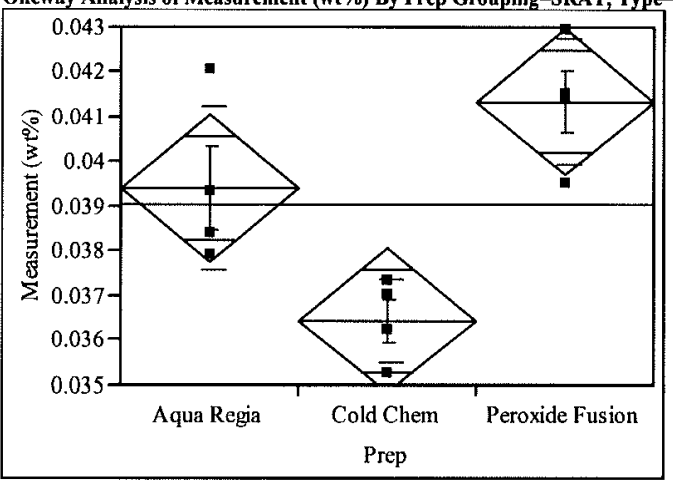

Oneway Anova

Summary of Fit

Rsquarc

Root Mean Square Error $\quad 0.001434$

Mean of Response $\quad 0.03905$

Observations (or Sum Wgts) $\quad 12$

Analysis of Variance

Source DF Sum of Squares Mean Square F Ratio Prob $>$ F

$\begin{array}{lrrrrr}\text { Prep } & 2 & 0.00004875 & 0.000024 & 11.8497 & 0.0030\end{array}$

$\begin{array}{lrrr}\text { Enor } \quad 9 & 0.00001852 & 2.057 \mathrm{e}-6\end{array}$

$\begin{array}{lllll}\begin{array}{l}\text { Means for Oneway Anova } \\ \text { Level }\end{array} \text { Number } & \text { Mean Std Error Lower } 95 \% \text { Upper } 95 \%\end{array}$

$\begin{array}{lrrrrr}\text { Level } & \text { Number } & \text { Mean } & \text { Std Error } & \text { Lower 95\% } & \text { Upper 95\% } \\ \text { Aqua Regia } & 4 & 0.039400 & 0.00072 & 0.03778 & 0.04102\end{array}$

$\begin{array}{llllll}\text { Cold Chem } & 4 & 0.039400 & 0.00072 & 0.03778 & 0.04102 \\ \text { Perom } & 4 & 0.036425 & 0.00072 & 0.03480 & 0.03805\end{array}$

$\begin{array}{llllll}\text { Cold Chem } & 4 & 0.036425 & 0.00072 & 0.03480 & 0.03805 \\ \text { Peroxide Fusion } & 4 & 0.041325 & 0.00072 & 0.03970 & 0.04295\end{array}$

Std Error uses a pooled estimate of error variance

Means and Std Deviations

Level Number Mean Std Dev Std Err Mean Lower 95\% Upper 95\%

$\begin{array}{lrrrrrr}\text { Level } & \text { Number } & \text { Mean } & \text { Std Dev Std Err Mean } & \text { Lower } \mathbf{9 5 \%} & \text { Upper 95\% } \\ \text { Aqua Regia } & 4 & 0.039400 & 0.001828 & 0.00091 & 0.03649 & 0.04231\end{array}$

$\begin{array}{lllllll}\text { Aqua Regia } & 4 & 0.039400 & 0.001828 & 0.00091 & 0.03649 & 0.04231 \\ \text { Cold Chem } & 4 & 0.036425 & 0.000939 & 0.00047 & 0.03493 & 0.03792\end{array}$

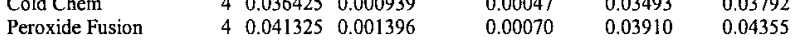

Tests that the Variances are Equal

$\begin{array}{lrrrr}\text { Level } & \text { Count } & \text { Std Dev } & \text { MeanAbsDif to Mean } & \text { MeanAbsDif to Median } \\ \text { Aqua Regia } & 4 & 0.0018276 & 0.0013000 & 0.0012500 \\ \text { Cold Chem } & 4 & 0.0009394 & 0.0007250 & 0.0007250 \\ \text { Peroxide Fusion } & 4 & 0.0013961 & 0.0009125 & 0.0008750\end{array}$

Test F Ratio DFNum DFDen Prob $>$ F

$\begin{array}{lrrrr}\text { O'Brien[.5] } & 0.5384 & 2 & 9 & 0.6014\end{array}$

$\begin{array}{lllll}\text { Brown-Forsythe } & 0.3099 & 2 & 9 & 0.7411 \\ \text { Levene } & 0.4897 & 2 & 9 & 0.6283\end{array}$

$\begin{array}{lllll}\text { Bartlett } & 0.5431 & 2 & . & 0.5810\end{array}$

Warning: Small sample sizes. Use Caution.

Welch Anova testing Means Eqqual, allowing Std Devs Not Equal

F Ratio DFNum DFDen Prob $>$ F

$\begin{array}{llll}16.0987 & 2 & 5.5849 & 0.0048\end{array}$

Means Comparisons

Comparisons for all pairs using Tukey-Kramer HSD

$\begin{array}{rr}\mathbf{q}^{\mathbf{*}} & \text { Alpha } \\ 2.79201 & 0.05\end{array}$

$\begin{array}{lrrr}\text { Abs(Dif)-LSD } & \text { Peroxide Fusion } & \text { Aqua Regia } & \text { Cold Chem } \\ \text { Peroxide Fusion } & -0.00283 & -0.00091 & 0.00207 \\ \text { Aqua Regia } & -0.00091 & -0.00283 & 0.00014 \\ \text { Cold Chem } & 0.00207 & 0.00014 & -0.00283\end{array}$

Cold Chem $\quad 0.00207 \quad 0.00014 \quad-0.00283$

Positive values show pairs of means that are significantly different.

$\begin{array}{lr}\text { Level } & \text { Mean } \\ \text { Peroxide Fusion A } & 0.04132500\end{array}$

Aqua Regia A 0.03940000

Cold Chem B 0.03642500

Levels not connected by same letter are significantly different. 
SRNL-STI-2011-00158, REVISION 0

Oneway Analysis of Measurement (wt $\%$ ) By Prep Grouping=SRAT, Type=Receipt, Element=Fe

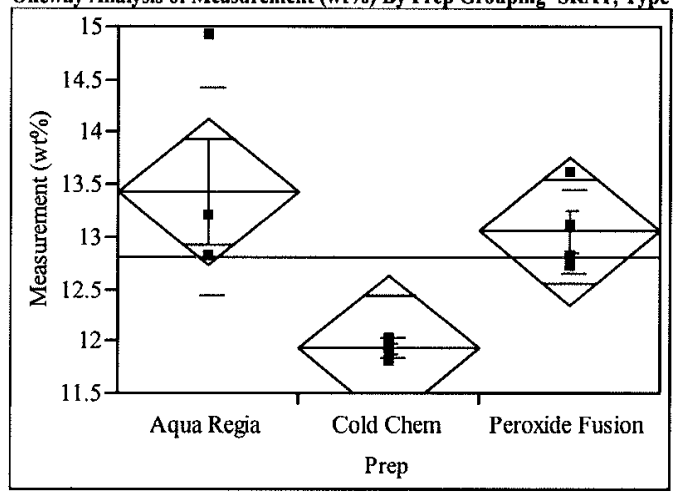

Oneway Anova

Summary of Fit

$\begin{array}{lr}\text { Rsquare } & 0.580357 \\ \text { Adj Rsquare } & 0.487103 \\ \text { Root Mean Square Error } & 0.625833 \\ \text { Mean of Response } & 12.8 \\ \text { Observations (or Sum Wgts) } & 12\end{array}$

Analysis of Variance

Source DF Sum of Squares Mean Square F Ratio Prob > F

$\begin{array}{lrrrrr}\text { Prep } & 2 & 4.8750000 & 2.43750 & 6.2234 & 0.0201\end{array}$

$\begin{array}{llll}\text { Prep } & 2 & 4.8750000 & 2.43750 \\ \text { Error } & 9 & 3.5250000 & 0.39167\end{array}$

$\begin{array}{lrr}\text { Error } & 9 & 3.5250000 \\ \text { C. Total } & 11 & 8.4000000\end{array}$

Means for Oneway Anova

Level Number Mean Std Error Lower 95\% Upper 95\%

$\begin{array}{lrrrrr}\text { Aqua Regia } & 4 & 13.4250 & 0.31292 & 12.717 & 14.133\end{array}$

$\begin{array}{llllll}\text { Cold Chem } & 4 & 11.9250 & 0.31292 & 11.217 & 12.633\end{array}$

$\begin{array}{llllll}\text { Peroxide Fusion } & 4 & 13.0500 & 0.31292 & 12.342 & 13.758\end{array}$

Std Error uses a pooled estimate of error variance

Means and Std Deviations

Level Number Mean Std Dev Std Err Mean Lower $95 \%$ Upper 95\%

$\begin{array}{lllllll}\text { Aqua Regia } & 4 & 13.4250 & 1.00125 & 0.50062 & 11.832 & 15.018\end{array}$

$\begin{array}{lllllll}\text { Cold Chem } & 4 & 11.9250 & 0.09574 & 0.04787 & 11.773 & 12.077 \\ \text { Peroxide Fusion } & 4 & 13.0500 & 0.40415 & 0.20207 & 12.407 & 13.693\end{array}$

0.20207

12.407

Tests that the Variances are Equal

Level

Count Std Dey MeanAbsDif to Mean MeanAbsDif to Median

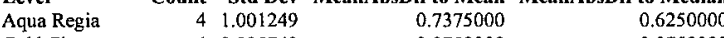

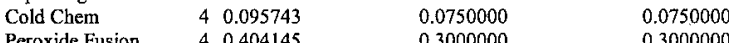

Test F Ratio DFNum DFDen Prob $>F$

$\begin{array}{lrrrr}\text { Test } & \text { F Ratio } & \text { DFNum } & \text { DFDen } & \text { Prob }>\text { F } \\ \text { O'Brien[.5] } & 1.3086 & 2 & 9 & 0.3171\end{array}$

$\begin{array}{lllll}\text { O'Brien[.5] } & 1.3086 & 2 & 9 & 0.3171 \\ \text { Brown-Forsythe } & 1.1738 & 2 & 9 & 0.3524\end{array}$

$\begin{array}{lllll}\text { Levene } & 4.2256 & 2 & 9 & 0.0508\end{array}$

$\begin{array}{lllll}\text { Bartlett } & 4.8203 & 2 & \text {. } & 0.0081\end{array}$

Warning: Small sample sizes. Use Caution.

Welch Anova testing Means Equal, allowing Std Devs Not Equal

F Ratio DFNum DFDen Prob $>$

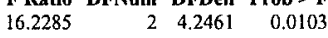

Means Comparisons

Comparisons for all pairs using Tukey-Kramer HSD

$\mathbf{q}^{*}$ Alpha

Abs(Dif)-LSD Aqua Regia Peroxide Fusion Cold Chem

$\begin{array}{lrrr}\text { Aqua Regia } & -1.2355 & -0.8605 & 0.2645\end{array}$

$\begin{array}{llll}\text { Peroxide Fusion } & -0.8605 & -1.2355 & -0.1105\end{array}$

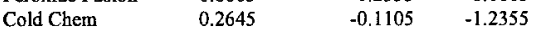

Positive values show pairs of means that are significantly different.

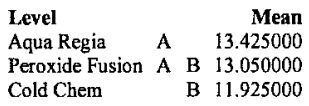

Levels not connected by same letter are significantly different.
Oneway Analysis of Measurement (wt \%) By Prep Grouping=SRAT, Type=Receipt, Element=K

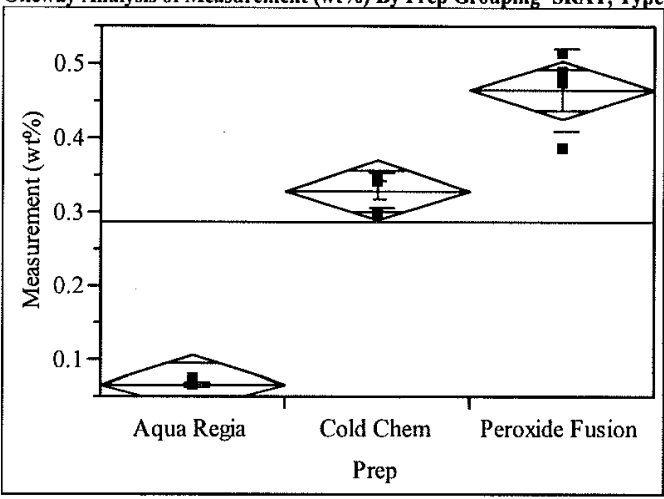

Oneway Anova

Summary of Fit

Adj Rsquare

Root Mean Square Error

Mean of Response

Observations (or Sum Wgts) $\quad 12$

Analysis of Variance

Source DF Sum of Squares Mean Square F Ratio Prob $>$ F

$\begin{array}{llllll}\text { Prep } & 2 & 0.32416000 & 0.162080 & 134.1654 & <.0001\end{array}$

$\begin{array}{lrrr}\text { Error } & 9 & 0.01087255 & 0.001208\end{array}$

Means for Oneway Anova

Level Number Mean Std Error Lower 95\% Upper 95\%

$\begin{array}{lrrrrr}\text { Aqua Regia } & \text { Number } & \text { Mean } & \text { St Error } & \text { Lower 95\% } & \text { Upper 95\% } \\ \text { A } & 0.067225 & 0.01738 & 0.02791 & 0.10654\end{array}$

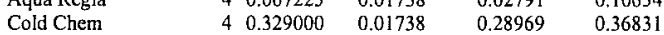

$\begin{array}{llllll}\text { Peroxide Fusion } & 4 & 0.329000 & 0.01738 & 0.28969 & 0.36831 \\ & 4 & 0.463000 & 0.01738 & 0.42369 & 0.50231\end{array}$

Std Error uses a pooled estimate of error variance

Means and Std Deviations

Level Number Mean Std Dev Std Err Mean Lower 95\% Upper 95\%

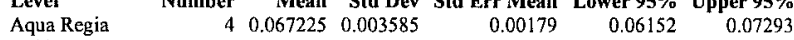

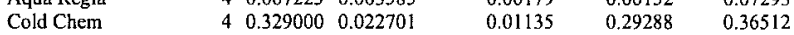

$\begin{array}{lllllll}\text { Cold Chem } & 4 & 0.329000 & 0.022701 & 0.01135 & 0.29288 & 0.36512 \\ \text { Peroxide Fusion } & 4 & 0.463000 & 0.055642 & 0.02782 & 0.37446 & 0.55154\end{array}$

Tests that the Variances are Equal

$\begin{array}{lrrrr}\text { Level } & \text { Count } & \text { Std Dev } & \text { MeanAbsDif to Mean } & \text { MeanAbsDif to Median } \\ \text { Aqua Regia } & 4 & 0.0035846 & 0.0025750 & 0.0025750 \\ \text { Cold Chem } & 4 & 0.0227010 & 0.0170000 & 0.0120000 \\ \text { Peroxide Fusion } & 4 & 0.0556417 & 0.0400000 & 0.0350000\end{array}$

Test F Ratio DFNum DFDen Prob $>$ F

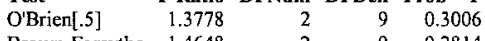

$\begin{array}{lllll}\text { Brown-Forsythe } & 1.4648 & 2 & 9 & 0.2814 \\ & 3.8985 & 2 & 9 & 0.0603\end{array}$

$\begin{array}{llll}\text { Bartlett } & 5.8194 & 2 & 0.0030\end{array}$

Warning: Small sample sizes. Use Caution.

Welch Anova testing Means Equal, allowing Std Devs Not Equal

F Ratio DFNum DFDen Prob $>$ F
307.2450

Means Comparisons

Comparisons for all pairs using Tukey-Kramer HSD

$\begin{array}{rr}\mathbf{q}^{*} & \text { Alpha } \\ 2.79201 & 0.05\end{array}$

Abs(Dif)-LSD Peroxide Fusion Cold Chem Aqua Regia

$\begin{array}{lrrr}\text { Peroxide Fusion } & -0.06862 & 0.06538 & 0.32716 \\ \text { Cold Chem } & 0.06538 & -0.06862 & 0.19316\end{array}$

$\begin{array}{llll}\text { Aqua Regia } & 0.32716 & 0.19316 & -0.06862\end{array}$

Positive values show pairs of means that are significantly different.

$\begin{array}{lrr}\text { Level } & & \text { Mean } \\ \text { Peroxide Fusion A } & & 0.46300000 \\ \text { Cold Chem } & \text { B } & 0.32900000 \\ \text { Aqua Regia } & \text { C } & 0.06722500\end{array}$

Levels not connected by same letter are significantly different. 
Oneway Analysis of Measurement (wt \%) By Prep Grouping=SRAT, Type=Receipt, Element=Li

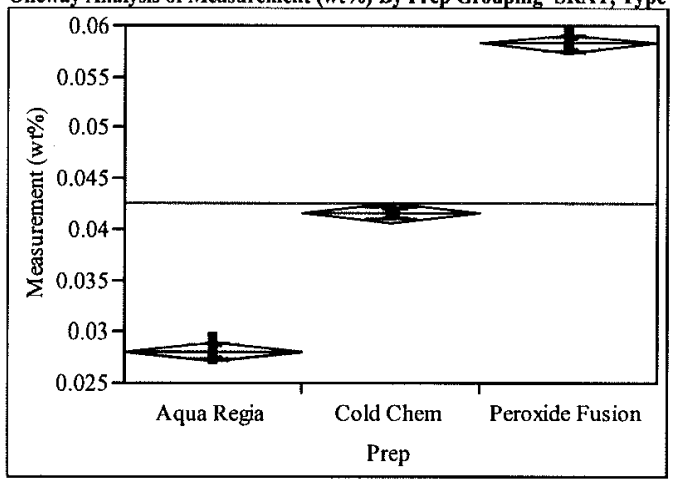

Oneway Anova

Summary of Fit

\begin{tabular}{lrrrrr} 
Rsquare & 0.996991 \\
Adj Rsquare & 0.996323 & & \\
Root Mean Square Error & 0.000783 & & \\
Mean of Response & 0.042567 & & \\
Observations (or Sum Wgts) & 12 & & & \\
\multicolumn{7}{c}{} \\
Analysis of Variance & & & & \\
Source & DF & Sum of Squares & Mean Square & F Ratio & Prob > F \\
Prep & 2 & 0.00182757 & 0.000914 & 1491.219 & $<.0001$ \\
Error & 9 & 0.00000552 & $6.128 \mathrm{e}-7$ & & \\
C. Total & 11 & 0.00183309 & & &
\end{tabular}

$\begin{array}{lrrrrr}\text { Means for Oneway Anova } & & & & \\ \text { Level } & \text { Number } & \text { Mean } & \text { Std Error } & \text { Lower 95\% } & \text { Upper 95\% } \\ \text { Aqua Regia } & 4 & 0.028000 & 0.00039 & 0.02711 & 0.02889 \\ \text { Cold Chem } & 4 & 0.041525 & 0.00039 & 0.04064 & 0.04241 \\ \text { Peroxide Fusion } & 4 & 0.058175 & 0.00039 & 0.05729 & 0.05906\end{array}$

Peroxide Fusion

Std Error uses a pooled estimate of error variance

\begin{tabular}{|c|c|c|c|c|c|c|}
\hline \multicolumn{7}{|c|}{ Means and Std Deviations } \\
\hline Level & Number & Mean & Std Dev & Std Err Mean & Lower 95\% & Upper $95 \%$ \\
\hline Aqua Regia & 4 & 0.028000 & 0.000949 & 0.00047 & 0.02649 & 0.02951 \\
\hline Cold Chem & 4 & 0.041525 & 0.000443 & 0.00022 & 0.04082 & 0.04223 \\
\hline Peroxide Fusion & 4 & 0.058175 & 0.000862 & 0.00043 & 0.05680 & 0.05955 \\
\hline
\end{tabular}

Tests that the Variances are Equal

$\begin{array}{lrrrr}\text { Level } & \text { Count } & \text { Std Dev } & \text { MeanAbsDif to Mean } & \text { MeanAbsDif to Median } \\ \text { Aqua Regia } & 4 & 0.0009487 & 0.0007000 & 0.0007000 \\ \text { Cold Chem } & 4 & 0.0004425 & 0.0003750 & 0.0003750 \\ \text { Peroxide Fusion } & 4 & 0.0008617 & 0.0006750 & 0.0006750\end{array}$

Test F Ratio DFNum DFDen Prob $>$ F

$\begin{array}{lrrrr}\text { Test } & \text { F Ratio } & \text { DFNum } & \text { DFDen } & \text { Prob }>\text { F } \\ \text { O'Brien[.5] } & 0.7481 & 2 & 9 & 0.5005 \\ \text { Brown-Forsythe } & 0.7246 & 2 & 9 & 0.5108 \\ \text { Levene } & 1.0064 & 2 & 9 & 0.4032 \\ \text { Bartlett } & 0.7373 & 2 & . & 0.4784\end{array}$

Warning: Small sample sizes. Use Caution.

Welch Anova testing Means Equal, allowing Std Devs Not Equal

$\begin{array}{rrrr}\text { F Ratio } & \text { DFNum } & \text { DFDen } & \text { Prob }>\text { F } \\ 1011.5611 & 2 & 5.3016 & <.0001\end{array}$

Means Comparisons

Comparisons for all pairs using Tukey-Kramer HSD

q $^{*}$ Alpha
2.79201

$\begin{array}{lrrr}\text { Abs(Dif)-LSD } & \text { Peroxide Fusion } & \text { Cold Chem } & \text { Aqua Regia } \\ \text { Peroxide Fusion } & -0.00155 & 0.01510 & 0.02863 \\ \text { Cold Chem } & 0.01510 & -0.00155 & 0.01198 \\ \text { Aqua Regia } & 0.02863 & 0.01198 & -0.00155\end{array}$

Positive values show pairs of means that are significantly different.

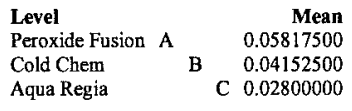

Levels not connected by same letter are significantly different.

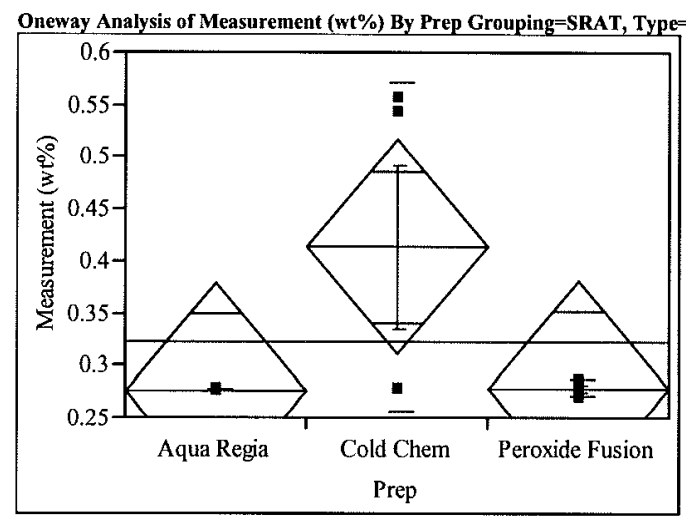

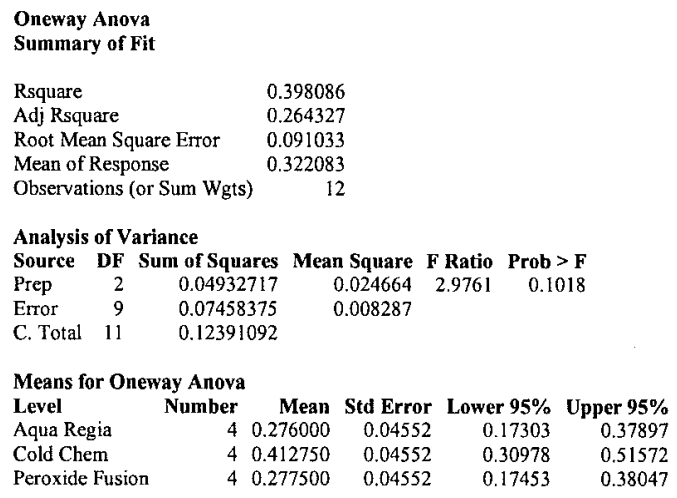

Std Eror uses a pooled estimate of error variance

Means and Std Deviations

Level Number Mean Std Dev Std Err Mean Lower 95\% Upper 95\%

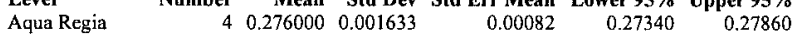

$\begin{array}{lllllll}\text { Aqua Regia } & 4 & 0.276000 & 0.001633 & 0.00082 & 0.27340 & 0.27860 \\ \text { Cold Chem } & 4 & 0.412750 & 0.157432 & 0.07872 & 0.16224 & 0.66326\end{array}$

$\begin{array}{lllllll}\text { Cold Chem } & 4 & 0.412750 & 0.157432 & 0.07872 & 0.16224 & 0.66326 \\ \text { Peroxide Fusion } & 4 & 0.277500 & 0.008583 & 0.00429 & 0.26384 & 0.29116\end{array}$

Tests that the Variances are Equal

$\begin{array}{lrrrr}\text { Level } & \text { Count } & \text { Std Dev } & \text { MeanAbsDif to Mean } & \text { MeanAbsDir to Median } \\ \text { Aqua Regia } & 4 & 0.0016330 & 0.0010000 & 0.0010000\end{array}$

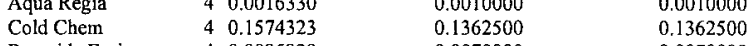

$\begin{array}{lllll}\text { Cold Chem } & 4 & 0.1574323 & 0.1362500 & 0.1362500 \\ \text { Peroxide Fusion } & 4 & 0.0085829 & 0.0070000 & 0.0070000\end{array}$

Test F Ratio DFNum DFDen Prob $>$ F

$\begin{array}{lrrrr}\text { O'Brien[.5] } & 361.3368 & 2 & 9 & <.0001\end{array}$

Brown-Forsythe $1175.9706 \quad 2 \quad 2 \quad 9<.0001$

$\begin{array}{lrrrr}\text { Levene } & 1648.6647 & 2 & 9 & <.0001\end{array}$

Bartlett

Welch Anova testing Means Equal, allowing Std Devs Not Equal

$\begin{array}{rrrr}\text { F Ratio } & \text { DFNum } & \text { DFDen } & \text { Prob }>\text { F } \\ 1.3494 & 2 & 4.14 & 0.3538\end{array}$

Means Comparisons

Comparisons for all pairs using Tukey-Kramer HSD

$q^{*}$ Alpha

Abs(Dif)-LSD Cold Chem Peroxide Fusion Aqua Regia

\begin{tabular}{lrrr} 
Cold Chem & -0.17972 & -0.04447 & -0.04297 \\
\hline
\end{tabular}

$\begin{array}{llll}\text { Peroxide Fusion } & -0.04447 & -0.17972 & -0.17822 \\ \text { Aqua Regia } & -0.04297 & -0.17822 & -0.17972\end{array}$

Positive values show pairs of means that are significantly different.

Level

Cold Chem Mean

$\begin{array}{lll}\text { Cold Chem } & \text { A } & 0.41275000 \\ \text { Peroxide Fusion } & \text { A } & 0.27750000\end{array}$

Aqua Regia A 0.27600000

Levels not connected by same letter are significantly different. 
Oneway Analysis of Measurement (wt \%) By Prep Grouping-SRAT, Type-Receipt, Element=Mn

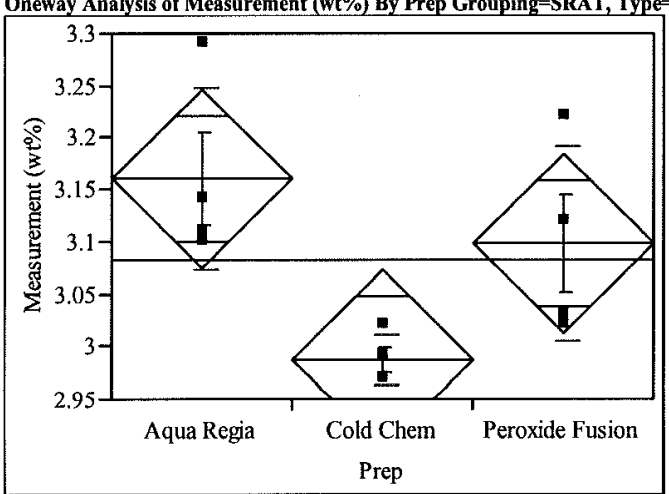

Oneway Anova

Summary of Fit

Rente

Root Mean Square Error $\quad 0.075388$

Mean of Response $\quad 3.081667$

Observations (or Sum Wgts)

12

Analysis of Variance

Source DF Sum of Squares Mean Square F Ratio Prob $>$ F

$\begin{array}{llllll}\text { Prep } & 2 & 0.06101667 & 0.030508 & 5.3680 & 0.0292\end{array}$

$\begin{array}{lrll}\text { Error } & 9 & 0.05115000 & 0.005683\end{array}$

C. Total $11 \quad 0.11216667$

\begin{tabular}{|c|c|c|c|c|c|}
\hline \multicolumn{2}{|c|}{ Means for Oneway Anova } & \multirow[b]{2}{*}{ Mean } & \multirow[b]{2}{*}{ Std Error } & \multirow[b]{2}{*}{ Lower $95 \%$} & \multirow[b]{2}{*}{ Upper 95\% } \\
\hline Level & Number & & & & \\
\hline Aqua Regia & 4 & 3.16000 & 0.03769 & 3.0747 & 3.2453 \\
\hline Cold Chem & 4 & 2.98750 & 0.03769 & 2.9022 & 3.0728 \\
\hline Peroxide Fusion & 4 & 3.09750 & 0.03769 & 3.0122 & 3.1828 \\
\hline
\end{tabular}

Std Error uses a pooled estimate of error variance

\begin{tabular}{|c|c|c|c|c|c|c|}
\hline Std & iations & & & & & \\
\hline Level & Number & Mean & Std Dev & Std Err Mean & Lower $95 \%$ & Upper 95\% \\
\hline Regia & 4 & 3.16000 & 0.088318 & 0.04416 & 3.0195 & 3.3005 \\
\hline Cold Che & 4 & 2.98750 & 0.023629 & 0.01181 & 2.9499 & 3.0251 \\
\hline Fusion & 4 & 3.09750 & 0.093229 & 0.04661 & 2.9492 & 3.2458 \\
\hline
\end{tabular}

Tests that the Variances are Equal

$\begin{array}{lrrrrr}\text { Level } & \text { Count } & \text { Std Dev } & \text { MeanAbsDif to Mean } & \text { MeanAbsDif to Median } \\ \text { Aqua Regia } & 4 & 0.0883176 & & 0.0650000 & 0.0550000 \\ \text { Cold Chem } & 4 & 0.0236291 & & 0.0175000 & 0.0175000 \\ \text { Peroxide Fusion } & 4 & 0.0932291 & & 0.0725000 & 0.0725000 \\ & & & & & \\ \text { Test } & \text { F Ratio } & \text { DFNum } & \text { DFDen } & \text { Prob > F } & \\ \text { O'Brien[.5] } & 0.9177 & 2 & 9 & 0.4338 & \\ \text { Brown-Forsythe } & 1.1868 & 2 & 9 & 0.3488 & \\ \text { Levene } & 2.6688 & 2 & 9 & 0.1230 & \\ \text { Bartlett } & 2.0628 & 2 & . & 0.1271 & \end{array}$

Warning: Small sample sizes. Use Caution.

Welch Anova testing Means Equal, allowing Std Devs Not Equal

F Ratio DFNum DFDen Prob $>$ F

Means Comparisons

Comparisons for all pairs using Tukey-Kramer HSD

$\mathrm{q}^{\star}$ Alpha

Abs(Dif)-LSD Aqua Regia Peroxide Fusion Cold Chem

$\begin{array}{lrrr}\text { Aqua Regia } & -0.14883 & -0.08633 & 0.02367\end{array}$

\begin{tabular}{llll} 
Peroxide Fusion & -0.08633 & -0.14883 & -0.03883 \\
\hline & 0.02367 & -0.03883 & -0.14883
\end{tabular}

$\begin{array}{llll}\text { Cold Chem } & 0.02367 & -0.03883 & .0 .14883\end{array}$

Positive values show pairs of means that are significantly different.

$\begin{array}{lrrr}\text { Level } & & \text { Mean } \\ \text { Aqua Regia } & \text { A } & 3.1600000 \\ \text { Peroxide Fusion } & \text { A } & \text { B } & 3.0975000 \\ \text { Cold Chem } & \text { B } 2.9875000\end{array}$

Levels not connected by same letter are significantly different.

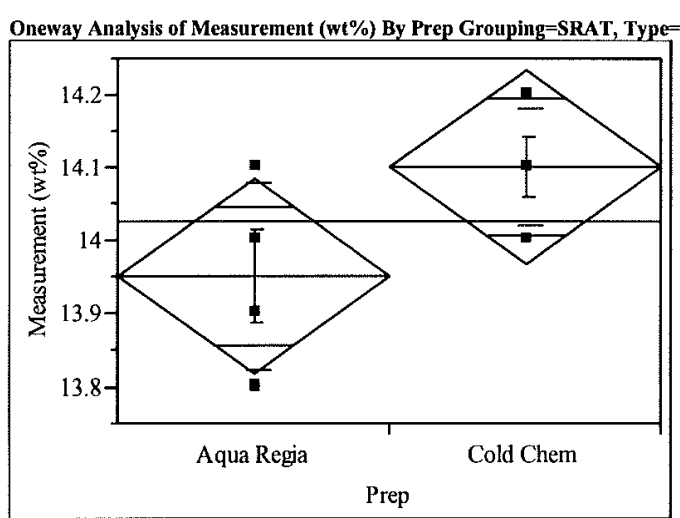

Missing Rows

4

Oneway Anova

Summary of Fit

Adj Rsquare

0.391304

Root Mean Squ

0.289855

Mean of Response

Observations (or Sum Wgts) $\quad 14.025$

Analysis of Variance

Source DF Sum of Squares Mean Square F Ratio Prob $>$ F

$\begin{array}{llllll}\text { Prep } & 1 & 0.04500000 & 0.045000 & 3.8571 & 0.0972\end{array}$

$\begin{array}{llll}\text { Error } & 6 & 0.07000000 & 0.011667\end{array}$

Means for Oneway Anova
Level Number Mean Std Error Lower 95\% Upper 95\%

$\begin{array}{lrrrrr}\text { Level } & \text { Number } & \text { Mean } & \text { Std Error } & \text { Lower 95\% } & \text { Upper 95\% } \\ \text { Aqua Regia } & 4 & 13.9500 & 0.05401 & 13.818 & 14.082\end{array}$

$\begin{array}{lrrrrr}\text { Aqua Regia } & 4 & 13.9500 & 0.05401 & 13.818 & 14.082 \\ \text { Cold Chem } & 4 & 14.1000 & 0.05401 & 13.968 & 14.232 \\ \text { Peroxide Fusion } & 0 & . & . & . & \text {. }\end{array}$$$
0
$$

Std Error uses a pooled estimate of error variance

$\begin{array}{lllll}\text { Means and Std Deviations } & & & \\ \text { Level } & \text { Number } & \text { Mean } & \text { Std Dev Std Err Mean Lower } 95 \% & \text { Upper } 95 \%\end{array}$

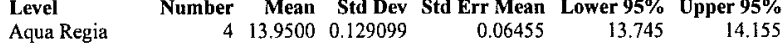

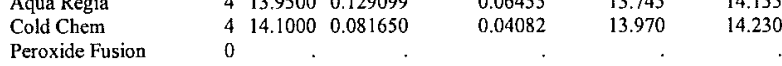

Tests that the Variances are Equal

$\begin{array}{lrrrr}\text { Level } & \text { Count } & \text { Std Dev } & \text { MeanAbsDif to Mean } & \text { MeanAbsDif to Median } \\ \text { Aqua Regia } & 4 & 0.1290994 & 0.1000000 & 0.1000000 \\ \text { Cold Chem } & 4 & 0.0816497 & 0.0500000 & 0.0500000 \\ \text { Peroxide Fusion } & 0 & . & 0.0000000 & 0.0000000\end{array}$

Test F Ratio DFNum DFDen Prob > F

$\begin{array}{lllll}\text { O'Brien[.5] } & 0.8640 & 1 & 6 & 0.3885\end{array}$

Brown-Forsythe $1.5000 \quad 1 \quad 60.2666$

$\begin{array}{lllll}\text { Levene } & 1.5000 & 1 & 6 & 0.2666\end{array}$

$\begin{array}{lllll}\text { Bartlett } & 0.5218 & \text { I } & . & 0.4701\end{array}$

Warning: Small sample sizes. Use Caution.

Welch Anova testing Means Equal, allowing Std Devs Not Equal

F Ratio DFNum DFDen Prob $>$ F

$\begin{array}{lll}3.8571 & 5.069-0.1060\end{array}$ 
SRNL-STI-2011-00158, REVISION 0

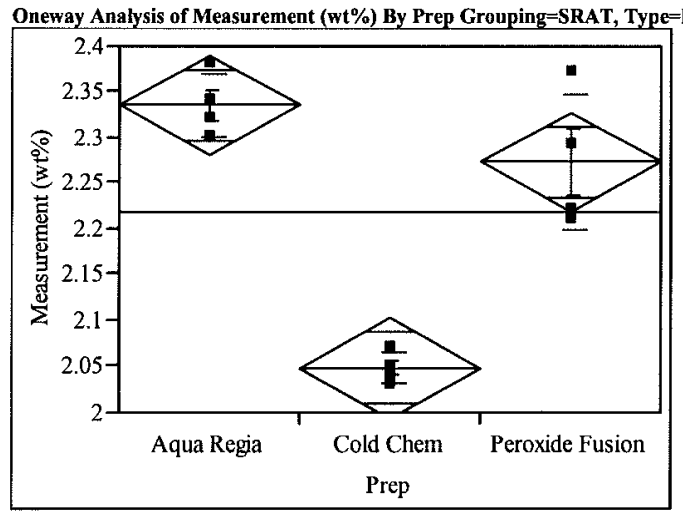

Oneway Anova

Summary of Fit

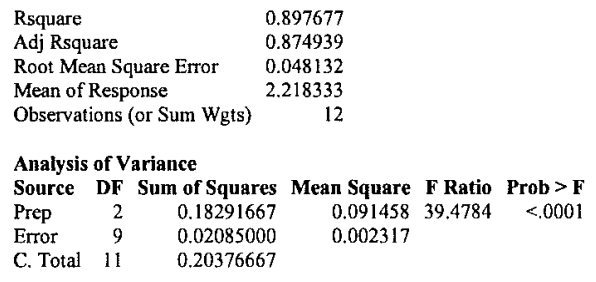

Means for Oneway Anova

$\begin{array}{lrrrrr}\text { Level } & \text { Number } & \text { Mean } & \text { Std Error } & \text { Lower 95\% } & \text { Upper 95\% } \\ \text { Aqua Regia } & 4 & 2.33500 & 0.02407 & 2.2806 & 2.3894 \\ \text { Cold Chem } & 4 & 2.04750 & 0.02407 & 1.9931 & 2.1019 \\ \text { Peroxide Fusion } & 4 & 2.27250 & 0.02407 & 2.2181 & 2.3269\end{array}$

Std Error uses a pooled estimate of error variance

Means and Std Deviations

$\begin{array}{lrrrrrr}\text { Level } & \text { Number } & \text { Mean } & \text { Std Dev } & \text { Std Err Mean } & \text { Lower 95\% } & \text { Upper 95\% } \\ \text { Aqua Regia } & 4 & 2.33500 & 0.034157 & 0.01708 & 2.2806 & 2.3894 \\ \text { Cold Chem } & 4 & 2.04750 & 0.017078 & 0.00854 & 2.0203 & 2.0747 \\ \text { Peroxide Fusion } & 4 & 2.27250 & 0.074106 & 0.03705 & 2.1546 & 2.3904\end{array}$

Tests that the Variances are Equal

\begin{tabular}{|c|c|c|c|c|c|}
\hline Level & Count & Std Dev & Mean & AbsDif to Mean & MeanAbsDif to Median \\
\hline Aqua Regia & 40 & 0.0341565 & & 0.0250000 & 0.0250000 \\
\hline Cold Chem & 40 & 0.0170783 & & 0.0125000 & 0.0125000 \\
\hline Peroxide Fusion & 40 & 0.0741058 & & 0.0575000 & 0.0575000 \\
\hline Test & F Ratio & DFNum & DFDen & Prob $>$ F & \\
\hline O'Brien[.5] & 2.0837 & 2 & 9 & 0.1804 & \\
\hline Brown-Forsythe & 3.3205 & 2 & 9 & 0.0832 & \\
\hline Levene & 4.3167 & 2 & 9 & 0.0485 & \\
\hline Bartlett & 2.4759 & 2 & . & 0.0841 & \\
\hline
\end{tabular}

Warning: Small sample sizes. Use Caution.

Welch Anova testing Means Equal, allowing Std Devs Not Equal

F Ratio DFNum DFDen Prob $>$ F

$\begin{array}{rrrr}108.4510 & 2 & 4.9159 & <.0001\end{array}$

Means Comparisons

Comparisons for all pairs using Tukey-Kramer HSD

$\mathbf{q}^{*}$ Alpha

Abs(Dif)-LSD Aqua Regia Peroxide Fusion Cold Chem

$\begin{array}{llll}\text { Aqua Regia } & -0.09502 & -0.03252 & 0.19248\end{array}$

$\begin{array}{llll}\text { Peroxide Fusion } & -0.03252 & -0.09502 & 0.12998\end{array}$

$\begin{array}{lrrr}\text { Cold Chem } & 0.19248 & 0.12998 & -0.09502\end{array}$

Positive values show pairs of means that are significantly different.

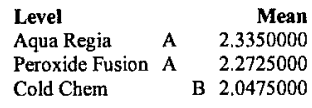

Levels not connected by same letter are significantly different.

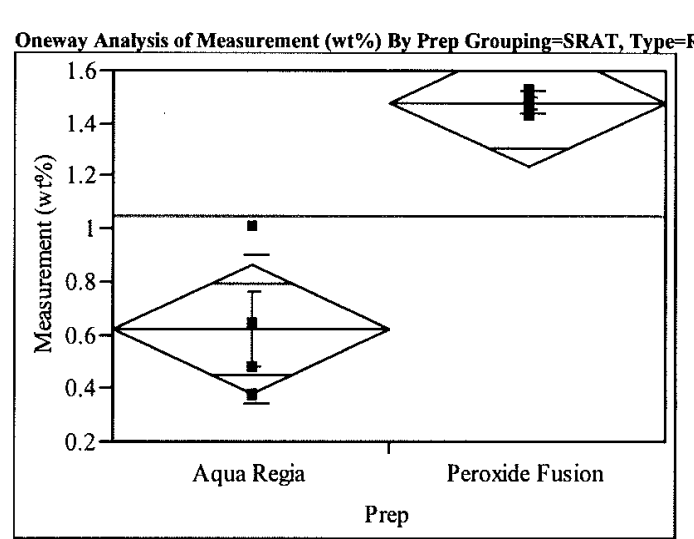

Missing Rows

4

Oneway Anova

Summary of Fit

Rsquare $\quad 0.86309$

Adj Rsquare $\quad 0.840273$

Root Mean Square Error $\quad 0.196892$

Mean of Response 1.049375

Observations (or Sum Wgts)

Analysis of Variance

Source DF Sum of Squares Mean Square F Ratio Prob $>$ F

$\begin{array}{llllll}\text { Prep } & 1 & 1.4663281 & 1.46633 & 37.8248 & 0.0008\end{array}$

0.03877

Means for Oneway Anova

Level Number Mean Std Error Lower 95\% Upper 95\%

$\begin{array}{lrrrrr}\text { Aqua Regia } & 4 & 0.62125 & 0.09845 & 0.3804 & 0.8621\end{array}$

Cold Chem

Peroxide Fusion

$\begin{array}{lrr}0 & 1.47750^{\circ} & 0.09845^{\circ}\end{array}$

$1.2366^{\circ} \quad 1.7184^{\circ}$

Std Error uses a pooled estimate of error variance

Means and Std Deviations

Level Number Mean Std Dev Std Err Mean Lower 95\% Upper 95\%

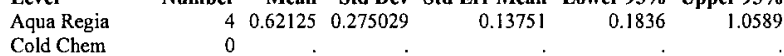

Cold Chem

0.1836

1.5467

Tests that the Variances are Equal

$\begin{array}{lrrrr}\text { Level } & \text { Count } & \text { Std Dev } & \text { MeanAbsDif to Mean } & \text { MeanAbsDif to Median } \\ \text { Aqua Regia } & 4 & 0.2750289 & 0.1972500 & 0.1972500 \\ \text { Cold Chem } & 0 & & 0.0000000 & 0.0000000 \\ \text { Peroxide Fusion } & 4 & 0.0434933 & 0.0325000 & 0.0325000\end{array}$

$\begin{array}{lrrrr}\text { Test } & \text { F Ratio } & \text { DFNum } & \text { DFDen } & \text { Prob }>\text { F } \\ \text { O'Brien[.5] } & 1.9554 & 1 & 6 & 0.2115 \\ \text { Brown-Forsythe } & 3.6296 & 1 & 6 & 0.1054 \\ \text { Levene } & 4.4776 & 1 & 6 & 0.0787 \\ \text { Bartlett } & 6.0471 & 1 & . & 0.0139\end{array}$

Warning: Small sample sizes. Use Caution.

Welch Anova testing Means Equal, allowing Std Devs Not Equal

F Ratio DFNum DFDen Prob $>$ F

$\begin{array}{llll}37.8248 & 1 & 3.15 & 0.0075\end{array}$ 
SRNL-STI-2011-00158, REVISION 0

Oneway Analysis of Measurement (wt\%) By Prep Grouping-SRAT, Type-Receipt, Element=Th

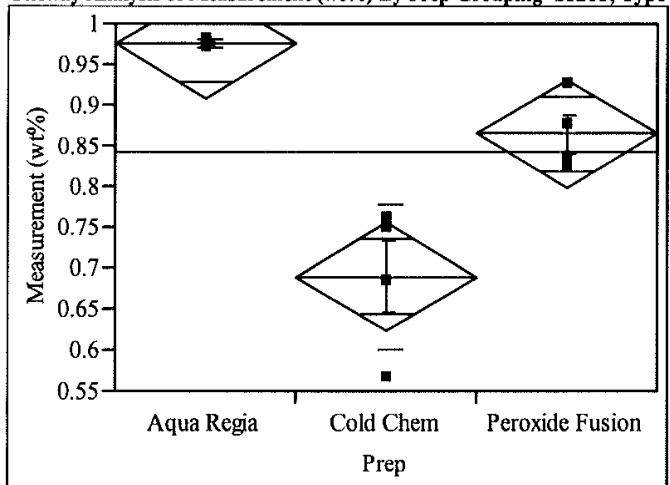

Oneway Anova

Summary of Fit

Rsquare $\quad 0.844638$

Adj Rsquare $\quad 0.810113$

Root Mean Square Error $\quad 0.058272$

Mean of Response $\quad 0.8425$

Observations (or Sum Wgts)

12

Analysis of Variance

Source DF Sum of Squares Mean Square F Ratio Prob $>$ F

$\begin{array}{llllll}\text { Prep } & 2 & 0.16614450 & 0.083072 & 24.4646 & 0.0002\end{array}$

$\begin{array}{lrrr}\text { Enror } & 9 & 0.03056050 & 0.003396\end{array}$

C. Total $11 \quad 0.19670500$

$\begin{array}{lrrrrr}\begin{array}{l}\text { Means for Oneway Anova } \\ \text { Level }\end{array} & \text { Number } & \text { Mean } & \text { Std Error } & \text { Lower 95\% } & \text { Upper 95\% } \\ \text { Aqua Regia } & 4 & 0.974500 & 0.02914 & 0.90859 & 1.0404 \\ \text { Cold Chem } & 4 & 0.688750 & 0.02914 & 0.62284 & 0.7547 \\ \text { Peroxide Fusion } & 4 & 0.864250 & 0.02914 & 0.79834 & 0.9302\end{array}$

Std Error uses a pooled estimate of error variance

$\begin{array}{lrrrrrr}\text { Means and Std Deviations } & & & & & \\ \text { Level } & \text { Number } & \text { Mean } & \text { Std Dev } & \text { Std Err Mean } & \text { Lower 95\% } & \text { Upper 95\% } \\ \text { Aqua Regia } & 4 & 0.974500 & 0.004655 & 0.00233 & 0.96709 & 0.98191 \\ \text { Cold Chem } & 4 & 0.688750 & 0.089343 & 0.04467 & 0.54658 & 0.83092\end{array}$

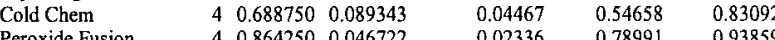

Tests that the Variances are Equal

\begin{tabular}{|c|c|c|c|c|c|}
\hline Level & Count & Std Dev & \multicolumn{2}{|c|}{ MeanAbsDif to Mean } & MeanAbsDif to Median \\
\hline Aqua Regia & 4 & 0.0046547 & & 0.0040000 & 0.0040000 \\
\hline Cold Chem & 4 & 0.0893434 & & 0.0652500 & 0.0652500 \\
\hline Peroxide Fusion & 4 & 0.0467217 & & 0.0357500 & 0.0357500 \\
\hline Test & F Ratio & DFNum & DFDen & Prob $>$ F & \\
\hline $\mathrm{O}^{\prime} \mathrm{Brien}[.5]$ & 1.6030 & 2 & 9 & 0.2538 & \\
\hline Brown-Forsythe & 2.9398 & 2 & 9 & 0.1041 & \\
\hline Levene & 4.0435 & 2 & 9 & 0.0559 & \\
\hline Bartlett & 6.0640 & 2 & & 0.0023 & \\
\hline
\end{tabular}

Warning: Small sample sizes. Use Caution.

Welch Anova testing Means Equal, allowing Std Devs Not Equal

$\begin{array}{rrrr}\text { F Ratio } & \text { DFNum } & \text { DFDen } & \text { Prob > F } \\ 26.8558 & 2 & 4.05 & 0.0046\end{array}$

Means Comparisons

Comparisons for all pairs using Tukey-Kramer HSD

$\mathbf{q}^{*}$ Alpha

Abs(Dif)-LSD Aqua Regia Peroxide Fusion Cold Chem

$\begin{array}{llll}\text { Aqua Regia } & -0.11504 & -0.00479 & 0.17071\end{array}$

$\begin{array}{llll}\text { Peroxide Fusion } & -0.00479 & -0.11504 & 0.06046\end{array}$

$\begin{array}{llll}\text { Cold Chem } & 0.17071 & 0.06046 & -0.11504\end{array}$

Positive values show pairs of means that are significantly different.

$\begin{array}{lrr}\text { Level } & & \text { Mean } \\ \text { Aqua Regia } & \text { A } & 0.97450000 \\ \text { Peroxide Fusion } & \text { A } & 0.86425000 \\ \text { Cold Chem } & \text { B } & 0.68875000\end{array}$

Levels not connected by same letter are significantly different

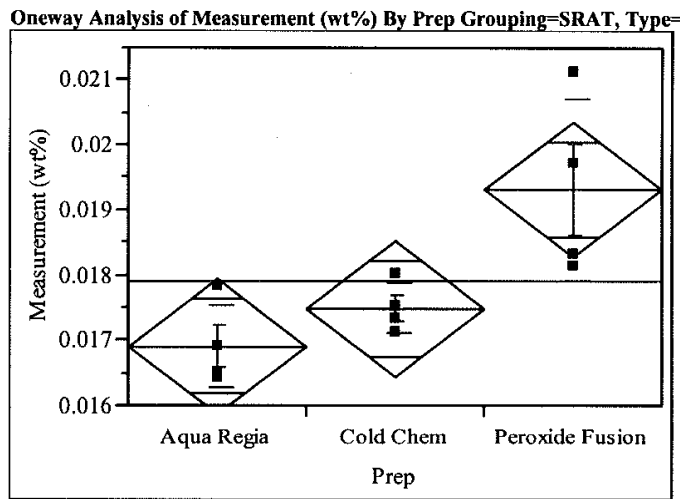

Oneway Anova

Summary of Fit

Adj Rsquare

0.54279
Root

Root Mean Square Error $\quad 0.000913$

$\begin{array}{lr}\text { Mean of Response } & 0.017892 \\ \text { Observations (or Sum Wgts) } & 12\end{array}$

Analysis of Variance

Source DF Sum of Squares Mean Square F Ratio Prob > F

$\begin{array}{llllll}\text { Prep } & 2 & 0.00001256 & 6.2808 \mathrm{e}-6 & 7.5295 & 0.0120\end{array}$

$\begin{array}{llll}\text { Error } & 9 & 0.00000751 & 8.3417 \mathrm{e}-7\end{array}$

C. Total $11 \quad 0.00002007$

Means for Oneway Anova

Level Number Mean Std Error Lower 95\% Upper 95\%

$\begin{array}{lllllr}\text { Aqua Regia } & 4 & 0.016900 & 0.00046 & 0.01587 & 0.01793\end{array}$

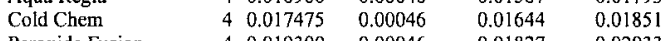

$\begin{array}{lllll}\text { Peroxide Fusion } \quad 4 & 0.019300 & 0.00046 & 0.01827 & 0.02033\end{array}$

Std Error uses a pooled estimate of error variance

Means and Std Deviations

Level Number Mean Std Dev Std Err Mean Lower 95\% Upper 95\%

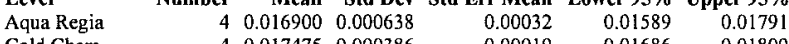

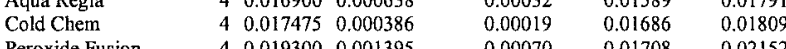

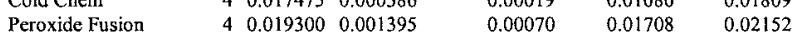

Tests that the Variances are Equal

$\begin{array}{lrrrr}\text { Level } & \text { Count } & \text { Std Dev } & \text { MeanAbsDif to Mean } & \text { MeanAbsDif to Median } \\ \text { Aqua Regia } & 4 & 0.0006377 & 0.0004500 & 0.0004500 \\ \text { Cold Chem } & 4 & 0.0003862 & 0.0002750 & 0.0002750 \\ \text { Peroxide Fusion } & 4 & 0.0013952 & 0.0011000 & 0.0011000\end{array}$

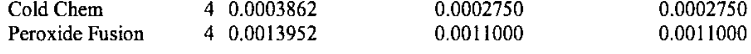

Test F Ratio DFNum DFDen Prob $>$ F

$\begin{array}{lllll}\text { O'Brien[.5] } & 2.2307 & 2 & 9 & 0.1634\end{array}$

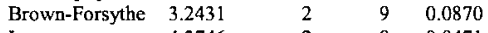

$\begin{array}{lllll}\text { Levene } & 4.3746 & 2 & 9 & 0.0471\end{array}$

$\begin{array}{llll}\text { Bartlett } & 2.0804 & 2 & 0.1249\end{array}$

Warning: Small sample sizes. Use Caution.

Welch Anova testing Means Equal, allowing Std Devs Not Equal

F Ratio DFNum DFDen Prob $>$ F

$\begin{array}{llll}4.4298 & 2 & 5.1701 & 0.0757\end{array}$

Means Comparisons

Comparisons for all pairs using Tukey-Kramer HSD

$\begin{array}{rr}q^{*} & \text { Alpha } \\ 2.79201 & 0.05\end{array}$

Abs(Dif)-LSD Peroxide Fusion Cold Chem Aqua Regia

$\begin{array}{llll}\text { Peroxide Fusion } & -0.00180 & 0.00002 & 0.00060\end{array}$

$\begin{array}{llll}\text { Cold Chem } & 0.00002 & -0.00180 & -0.00123\end{array}$

$\begin{array}{llll}\text { Aqua Regia } & 0.00060 & -0.00123 & -0.00180\end{array}$

Positive values show pairs of means that are significantly different.

Level

Peroxide Fusion A $\quad 0.01930000$

Cold Chem B 0.01747500

Aqua Regia $\quad$ B 0.01690000

Levels not connected by same letter are significantly different. 
SRNL-STI-2011-00158, REVISION 0

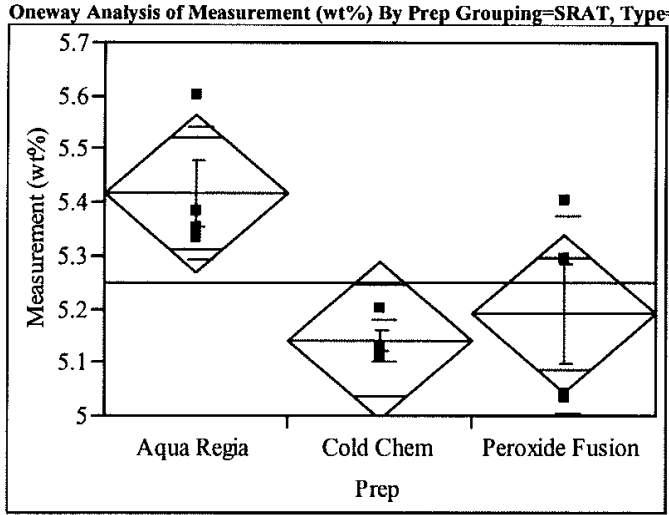

Oneway Anova

Summary of Fit

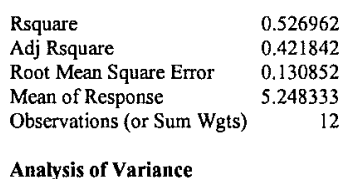

Analysis of Variance

Source DF Sum of Squares Mean Square F Ratio Prob $>$ F

$\begin{array}{lllllll}\text { Prep } & 2 & 0.17166667 & 0.085833 & 5.0130 & 0.0344\end{array}$

$\begin{array}{lrll}\text { Error } & 9 & 0.15410000 & 0.017122\end{array}$

C. Total $11 \quad 0.3257666$

\begin{tabular}{|c|c|c|c|c|c|}
\hline \multicolumn{6}{|c|}{ Means for Oneway Anova } \\
\hline Level & Number & Mean & Std Error & Lower $95 \%$ & Upper 95\% \\
\hline Aqua Regia & 4 & 5.41500 & 0.06543 & 5.2670 & 5.5630 \\
\hline Cold Chem & 4 & 5.14000 & 0.06 & 4.9920 & 5.2 \\
\hline Peroxide Fusion & 4 & 5.19000 & 0.06543 & 5.0420 & 5.3380 \\
\hline
\end{tabular}

Std Error uses a pooled estimate of error variance

\begin{tabular}{|c|c|c|c|c|c|c|}
\hline & & & & & & \\
\hline Level & Number & Mean & Std Dev & Std Err Mean & Lower 95\% & Upper $95 \%$ \\
\hline Aqua Regia & 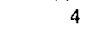 & 5.41500 & 0.125033 & 0.06252 & 5.2160 & 5.6 \\
\hline Cold & 4 & & 0.0 & 0 & 5 & \\
\hline Peroxide Fusion & 4 & 5.19000 & 0.184572 & 0.09229 & 4.8963 & 5.4837 \\
\hline
\end{tabular}

Tests that the Variances are Equal

\begin{tabular}{|c|c|c|c|c|c|}
\hline Level & Count & Std Dev & \multicolumn{2}{|c|}{ MeanAbsDif to Mean } & MearAbsDif to Median \\
\hline Aqua Regia & 4 & 0.1250333 & & 0.0925000 & 0.0750000 \\
\hline Cold Chem & 4 & 0.0408248 & & 0.0300000 & 0.0250000 \\
\hline Peroxide Fusion & 4 & 0.1845716 & & 0.1550000 & 0.1550000 \\
\hline Test & F Ratio & DFNum & DFDen & Prob $>$ F & \\
\hline O'Brien[.5] & 2.6412 & 2 & 9 & 0.1252 & \\
\hline Brown-Forsythe & 3.3362 & 2 & 9 & 0.0824 & \\
\hline Levene & 6.9703 & 2 & 9 & 0.0148 & \\
\hline Bartlett & 2.2635 & 2 & & 0.1040 & \\
\hline
\end{tabular}

Warning: Small sample sizes. Use Caution.

Welch Anova testing Means Equal, allowing Std Devs Not Equal

$\begin{array}{rrr}\text { F Ratio DFNum DFDen } & \text { Prob }>\text { F } \\ 7.6520 & 2.5475 & 0.0351\end{array}$

Means Comparisons

Comparisons for all pairs using Tukey-Kramer HSD

Comparisons for

$2.79201 \quad 0.05$

Abs(Dif)-LSD Aqua Regia Peroxide Fusion Cold Chem

$\begin{array}{lrrr}\text { Aqua Regia } & -0.25833 & -0.03333 & 0.01667\end{array}$

\begin{tabular}{llll} 
Peroxide Fusion & -0.03333 & -0.25833 & -0.20833 \\
\hline
\end{tabular}

Cold Chem

Positive values show pairs of means that are significantly different. $\begin{array}{lrr}\text { Level } & \text { Mean } \\ \text { Aqua Regia A } & 5.4150000\end{array}$

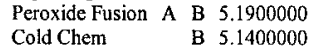

Levels not connected by same letter are significantly different.

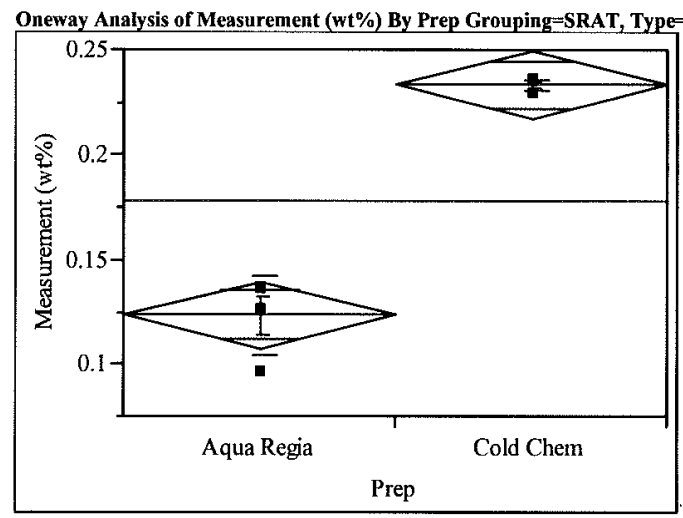

Missing Rows

4

Oneway Anova

Summary of Fit

Rsquare

Adj Rsquare

Root Mean Square Enror $\quad 0.949821$

Mean of Response 0.178

$\begin{array}{lr}\text { Observations (or Sum Wgts) } & 8\end{array}$

Analysis of Variance

Source DF Sum of Squares Mean Square F Ratio Prob $>$ F

$\begin{array}{lrrrrr}\text { Prep } & 1 & 0.02411208 & 0.024112 & 133.5011 & <.0001\end{array}$

$\begin{array}{llll}\text { Error } & 6 & 0.00108368 & 0.000181 \\ \text { C. Total } & 7 & 0.02519576 & \end{array}$

$\begin{array}{llll}\text { Means for Oneway Anova } \\ \text { Level } & \text { Number } & \text { Mean Std Error Lower 95\% Upper 95\% }\end{array}$

$\begin{array}{lrrrrr}\text { Level } & \text { Number } & \text { Mean } & \text { Std Error } & \text { Lower 95\% } & \text { Upper 95\% } \\ \text { Aqua Regia } & 4 & 0.123200 & 0.00672 & 0.10676 & 0.13964\end{array}$

$\begin{array}{llllll}\text { Aqua Regia } & 4 & 0.123200 & 0.00672 & 0.10676 & 0.13964 \\ \text { Cold Chem } & 4 & 0.233000 & 0.00672 & 0.21656 & 0.24944\end{array}$

Peroxide Fusion

$$
0
$$

Std Error uses a pooled estimate of error variance

Means and Std Deviations

Level Number Mean Std Dev Std Err Mean Lower 95\% Upper 95\%

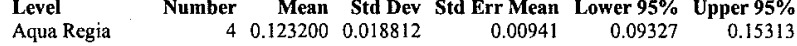

$\begin{array}{lllllll}\text { Aqua Regia } & 4 & 0.123200 & 0.018812 & 0.00941 & 0.09327 & 0.15313 \\ \text { Cold Chem } & 4 & 0.233000 & 0.002708 & 0.00135 & 0.22869 & 0.23731\end{array}$

Peroxide Fusion$$
0
$$

Tests that the Variances are Equal

$\begin{array}{lrrrr}\text { Level } & \text { Count } & \text { Std Dev } & \text { MeanAbsDif to Mean } & \text { MeanAbsDif to Median } \\ \text { Aqua Regia } & 4 & 0.0188121 & 0.0137000 & 0.0123000 \\ \text { Cold Chem } & 4 & 0.0027080 & 0.0020000 & 0.0015000 \\ \text { Peroxide Fusion } & 0 & . & 0.0000000 & 0.0000000\end{array}$

Test F Ratio DFNum DFDen Prob $>$ F

$\begin{array}{lrrrr}\text { O'Brien[.5] } & 1.5804 & 1 & 6 & 0.2554 \\ \text { Brown-Forsythe } & 2.0383 & 1 & 6 & 0.2033\end{array}$

$\begin{array}{lllll}\text { Brown-Forsythe } & 2.0383 & 1 & 6 & 0.2033 \\ \text { Levene } & 5.1833 & 1 & 6 & 0.0631\end{array}$

$\begin{array}{lllll}\text { Bartlett } & 6.5090 & 1 & . & 0.0107\end{array}$

Warning: Small sample sizes. Use Caution.

Welch Anova testing Means Eqqual, allowing Std Devs Not Equal

F Ratio DFNum DFDen Prob $>$ F 
Distribution

M.J. Barnes, 773-A

J.M. Bricker, 704-27S

L.M. Chandler, 773-A

C.J. Coleman, 773-A

T.B. Edwards, 773-42A

M.T. Feller, 704-28S

T.L. Fellinger, 704-26S

C.M. Gregory, 773-A

C.C. Herman, 999-W

E.W. Holtzscheiter, 704-15S

J.F. Iaukea, 704-30S

P.L. Lee, 773-A

S.L. Marra, 773-A

R.T. McNew, 704-S

R.N. Mahannah, 704-28S

A.B. Osteen, 704-28S

J.E. Occhipinti, 704-S

J.M. Pareizs, 773-A

D.K. Peeler, 999-W

H.M. Pittman, 704-27S

J.W. Ray, 704-S

D.C. Sherburne, 704-S

A.V. Staub, 704-27S

M.E. Stone, 999-W

ADS Files 